January 2001

POST-RELEASE ATTRIBUTES AND SURVIVAL OF HATCHERY AND NATURAL FALL CHINOOK SALMON IN THE SNAKE RIVER

Annual Report 1999

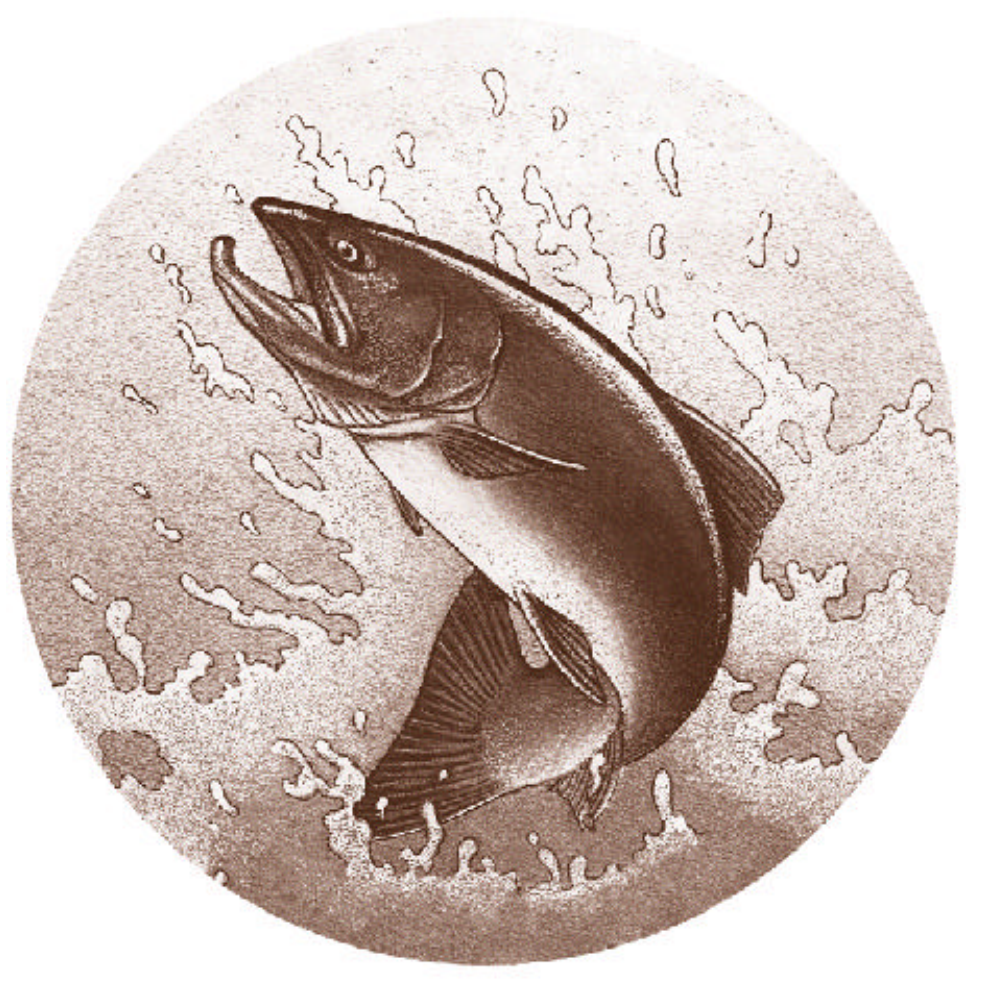

DOE/BP-00000161-1 
This report was funded by the Bonneville Power Administration (BPA), U.S. Department of Energy, as part of BPA's program to protect, mitigate, and enhance fish and wildlife affected by the development and operation of hydroelectric facilities on the Columbia River and its tributaries. The views of this report are the author's and do not necessarily represent the views of BPA.

This document should be cited as follows:

Tiffan, Kenneth F. Dennis W. Rondorf - U.S. Geological Survey, William P. Connor, Howard L. Burge - U.S. Fish and Wildlife Service, Post-Release Attributes And Survival Of Hatchery And Natural Fall Chinook Salmon In The Snake

River Annual Report 1999, Report to Bonneville Power Administration, Contract No. 00000161- , Project No.

199102900, 140 electronic page (BPA Report DOE/BP-00000161-1)

This report and other BPA Fish and Wildlife Publications are available on the Internet at:

\section{http://www.efw.bpa.gov/cgi-bin/efw/FW/publications.cgi}

For other information on electronic documents or other printed media, contact or write to:

Bonneville Power Administration

Environment, Fish and Wildlife Division

P.O. Box 3621

905 N.E. 11th Avenue

Portland, OR 97208-3621

Please include title, author, and DOE/BP number in the request. 


\section{Annual Report 1999}

POST-RELEASE ATTRIBUTES AND SURVIVAL OF HATCHERY AND NATURAL FALL CHINOOK SALMON IN THE SNAKE RIVER

January 2001
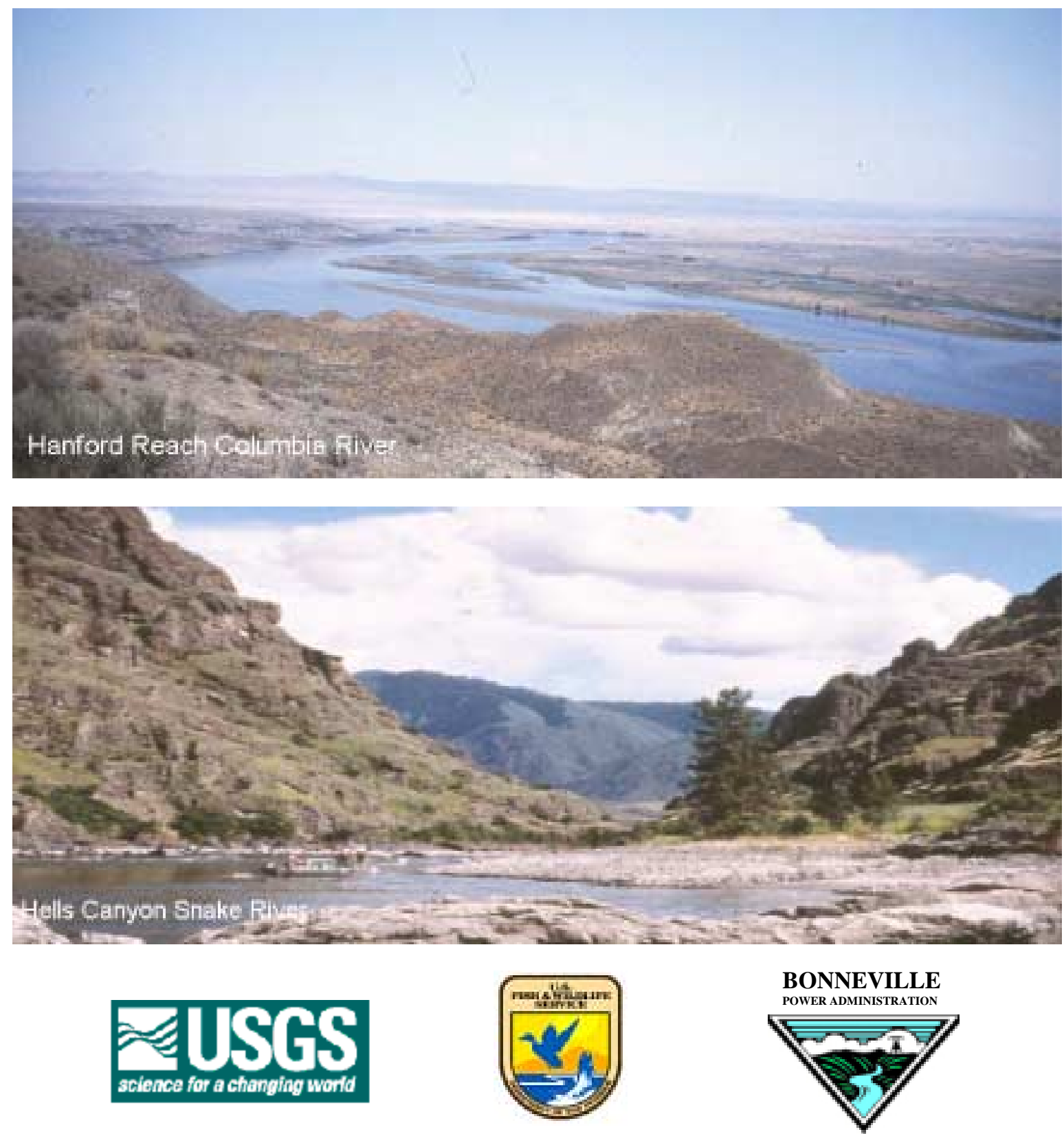


\title{
POST-RELEASE ATTRIBUTES AND SURVIVAL OF HATCHERY AND NATURAL FALL CHINOOK SALMON IN THE SNAKE RIVER \\ ANNUAL REPORT 1999
}

\author{
Prepared by: \\ Kenneth F. Tiffan \\ and \\ Dennis W. Rondorf \\ U.S. Geological Survey \\ Biological Resources Division \\ Columbia River Research Laboratory \\ Cook, WA 98605 \\ and \\ William P. Connor \\ and \\ Howard L. Burge \\ U.S. Fish and Wildlife Service \\ Idaho Fishery Resource Office \\ Ahshaka, ID 83520 \\ Prepared for: \\ U.S. Department of Energy \\ Bonneville Power Administration \\ Environment, Fish and Wildlife Department \\ P.O. BOx 3621 \\ Portland, OR 97208-3621 \\ Project Number 91-029 \\ Contract Number DE-AI79-91BP21708
}

http://wWW.efw.bpa.gov/Environment/EW/EWP / DOCS /REPORTS / GENERAL

January 2001 


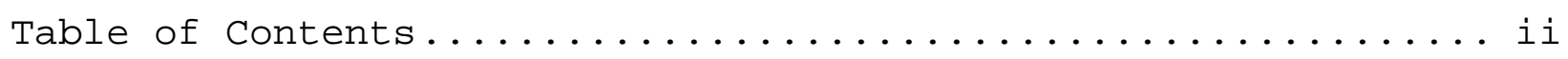

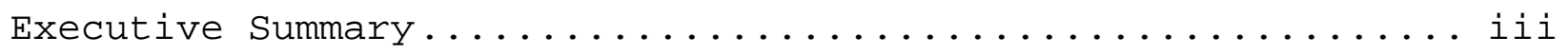

Acknowledgements.............................

Chapter One:

Run Composition and Early Life History Attributes of Wild

Subyearling Chinook Salmon Recaptured After Migrating

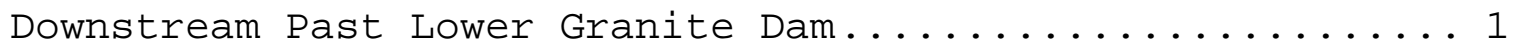

Chapter Two:

The Role of Rapid Growth on Seaward Migration of Wild

Subyearling Spring Chinook Salmon in the Snake River.... 14

Chapter Three:

Snake River Fall Chinook Salmon and Early Life History and

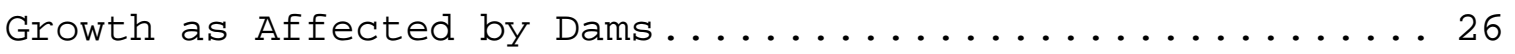

Chapter Four:

Modeling Flow-dependent Changes in Juvenile Fall Chinook

Salmon Rearing Habitat and Entrapment Area in the Hanford

Reach of the Columbia River...................60

Chapter Five:

Subyearling Fall Chinook Salmon Use of Shoreline Riprap

Habitats in a Reservoir of the Columbia River..........990

Chapter Six:

Community, Temporal, and Spatial Dynamics of Zooplankton in

McNary and John Day Reservoirs, Columbia River......... 106 


\section{EXECUTIVE SUMMARY}

This report summarizes results of research activities conducted in 1999 and years previous. In an effort to provide this information to a wider audience, the individual chapters in this report have been submitted as manuscripts to peer-reviewed journals. These chapters communicate significant findings that will aid in the management and recovery of fall chinook salmon in the Columbia River Basin.

Abundance and timing of seaward migration of Snake River fall chinook salmon was indexed using passage data collected at Lower Granite Dam for five years. We used genetic analyses to determine the lineage of fish recaptured at Lower Granite Dam that had been previously PIT tagged. We then used discriminant analysis to determine run membership of PIT-tagged smolts that were not recaptured to enable us to calculate annual run composition and to compared early life history attributes of wild subyearling fall and spring chinook salmon. Because spring chinook salmon made up from 15.1 to $44.4 \%$ of the tagged subyearling smolts that were detected passing Lower Granite Dam, subyearling passage data at Lower Granite Dam can only be used to index fall chinook salmon smolt abundance and passage timing if genetic samples are taken to identify run membership of smolts. Otherwise, fall chinook salmon smolt abundance would be overestimated and timing of fall chinook salmon smolt passage would appear to be earlier and more protracted than is the case.

In previous work, we demonstrated that subyearling spring chinook salmon can make up a significant portion of the presumably fall chinook salmon population migrating past Lower Granite Dam. We examined growth data to determine if growth opportunity could be used to explain this life history strategy . By June, wild subyearling spring chinook salmon rearing along the shorelines of the Snake River had grown to mean fork lengths ranging from 78.4 to $87.2 \mathrm{~mm}$. We also found that rapid growth (range 1.0 to $1.5 \mathrm{~mm} / \mathrm{d}$ ) continued as wild spring chinook salmon began seaward migration as subyearlings. We conclude that rapid growth promoted by the rearing environment plays an important role in determining age at seaward migration for wild spring chinook salmon, and that rapid growth contributed to earlier than normal seaward migration by the wild subyearling spring chinook salmon we studied.

The effects of dams on the growth and life history attributes of Snake River juvenile fall chinook salmon are explored in the third chapter. Dams have blocked passage to the 
historic spawning areas, confined spawning to relatively coolwater areas, altered the water temperature regimes of these areas, and impounded the downstream migration route of smolts. Dams ultimately reduce the production potential of the snake River basin for fall chinook salmon by extending the freshwater life cycle into late summer when conditions for smoltification and survival are poor.

We used hydrodynamic modeling and a GIS-based analysis to quantify the amount of juvenile fall chinook salmon rearing habitat and entrapment area in a 33-km section of the Hanford Reach. Most of the shoreline habitats in the Hanford Reach were suitable for juvenile fall chinook salmon, although the amount of available area generally decreased as flows increased. The area of entrapment pools created by flow decreases was greatly reduced at flows exceeding $4,531 \mathrm{~m}^{3} / \mathrm{s}$, but the highest net gain in entrapment area was during $850 \mathrm{~m}^{3} / \mathrm{s}$ decreases in flow when river discharges were between 5,381 and $5,664 \mathrm{~m}^{3} / \mathrm{s}$. We believe that limiting flow fluctuations at all discharges from Priest Rapids Dam would provide additional protection for juvenile fall chinook salmon beyond the measures that are currently in place.

Habitat assessments were made in McNary Reservoir to specifically address juvenile fall chinook salmon use of riprap shoreline habitat. Fall chinook salmon preferred natural shoreline habitats but generally avoided riprap shorelines. Riprap avoidance could not be linked to a specific variable but is probably due to a combination of substrate size, water depth, and lateral slope. This finding has important implications for rearing fall chinook salmon since much of the shorelines of mainstem reservoirs are lined with riprap.

Because of the potential for migrating fall chinook salmon to use zooplankton as a food resource, we examined the dynamics of the zooplankton population in MCNary and John Day reservoirs. The five major taxa collected were Bosmina longirostris, Daphnia spp., cyclopoid copepods, rotifers, and calanoid copepods. Temporal differences in zooplankton parameters were largely due to yearly differences in temperature and discharge. Overall mean abundances of crustacean zooplankton taxa were greater in John Day Reservoir than in McNary Reservoir. Increased zooplankton abundance and Daphnia spp. biomass were positively correlated with increased temperature and negatively correlated with decreased flow. A dramatic shift in cladoceran abundance and size in late August may be an indication of size selective predation by juvenile American shad. 
We thank individuals in the U.S. Fish and Wildlife Service, National Marine Fisheries Service, Nez Perce Tribe, Washington Department of Fish and Wildlife, Fish Passage Center, University of Idaho, and the U.S. Army Corps of Engineers that assisted with project activities. We extend special thanks to our colleagues at the Biological Resources Division and the Idaho Fishery Resource Office of the U.S. Fish and Wildlife Service for their assistance. We appreciate the assistance of Debbie Docherty, Project Manager, Bonneville Power Administration. 


\title{
CHAPTER ONE
}

Run Composition and Early Life History Attributes of Wild Subyearling Chinook Salmon Recaptured after Migrating Downstream Past Lower Granite Dam

by

William P. Connor

U. S. Fish and Wildlife Service

P.O. Box 18, Ahsahka, Idaho 83520

Theodore C. Bjornn

U. S. Geological Survey

Idaho Cooperative Fish and Wildlife Research Unit

University of Idaho, Moscow, Idaho 83843

Howard L. Burge

U. S. Fish and Wildlife Service

P.O. Box 18, Ahsahka, Idaho 83520

Anne R. Marshall and H. Lee Blankenship

Washington Department of Fish and Wildlife

600 Capitol Way North, Olympia, Washington 98501

\author{
R. Kirk Steinhorst \\ Division of Statistics \\ University of Idaho, Moscow, Idaho 83844-1136 \\ Kenneth F. Tiffan \\ U. S. Geological Survey \\ Cook, Washington 98605
}




\section{Introduction}

Chinook salmon (Oncorhynchus tshawytscha) are indigenous to streams throughout the Snake River Basin. Wild Snake River fall chinook salmon spawn in the mainstem Snake, lower Clearwater, and lower Grande Ronde rivers (Figure 1) from October to early December (Groves and Chandler 1999). Fall chinook salmon typically have an "ocean-type" (Healey 1991) early life history. Fry emerge from the gravel primarily from April to June, parr rear along the shoreline of the Snake River from April to July, and smolts typically migrate seaward during summer as subyearlings (W. P. Connor, U. S. Fish and Wildlife Service, unpublished data).

Wild Snake River spring/summer (hereafter, spring) chinook salmon typically have a "stream-type" (Healey 1991) early life history. Adult spring chinook salmon spawn mainly in small tributaries of the Imnaha, Salmon, Grande Ronde, and Clearwater rivers (Figure 1) in August through early September (Howell et al. 1984). Fry emerge from the gravel primarily from late January through early May (Howell et al. 1984). Parr typically rear in natal tributaries until late summer or fall, migrate downstream to overwinter in mainstem tributaries of the snake River, and begin seaward migration the following spring as yearlings (Chapman and Bjornn 1969; Bjornn 1971).

Abundance and timing of seaward migration of subyearling Snake River fall chinook salmon are indexed annually at Lower Granite Dam (Figure 1), which is the first dam smolts encounter en route to the Pacific Ocean. However, not all of the subyearling smolts are fall chinook salmon. Some wild snake River spring chinook salmon migrate seaward as subyearlings, as shown by Marshall et al. (2000), who found that from 5 to 63\% of the smolts they sampled at Lower Granite Dam from 1991 to 1995 were wild subyearling spring chinook salmon. In this paper, we expand on the findings of Marshall et al. (2000) by providing more complete estimates of the proportions of subyearling fall and spring chinook salmon that passed Lower Granite Dam (i.e., run composition) in 1993, 1994, 1996, 1997, and 1998. We also compared several early life history attributes of wild subyearling fall and spring chinook salmon including time of passage at Lower Granite Dam. 


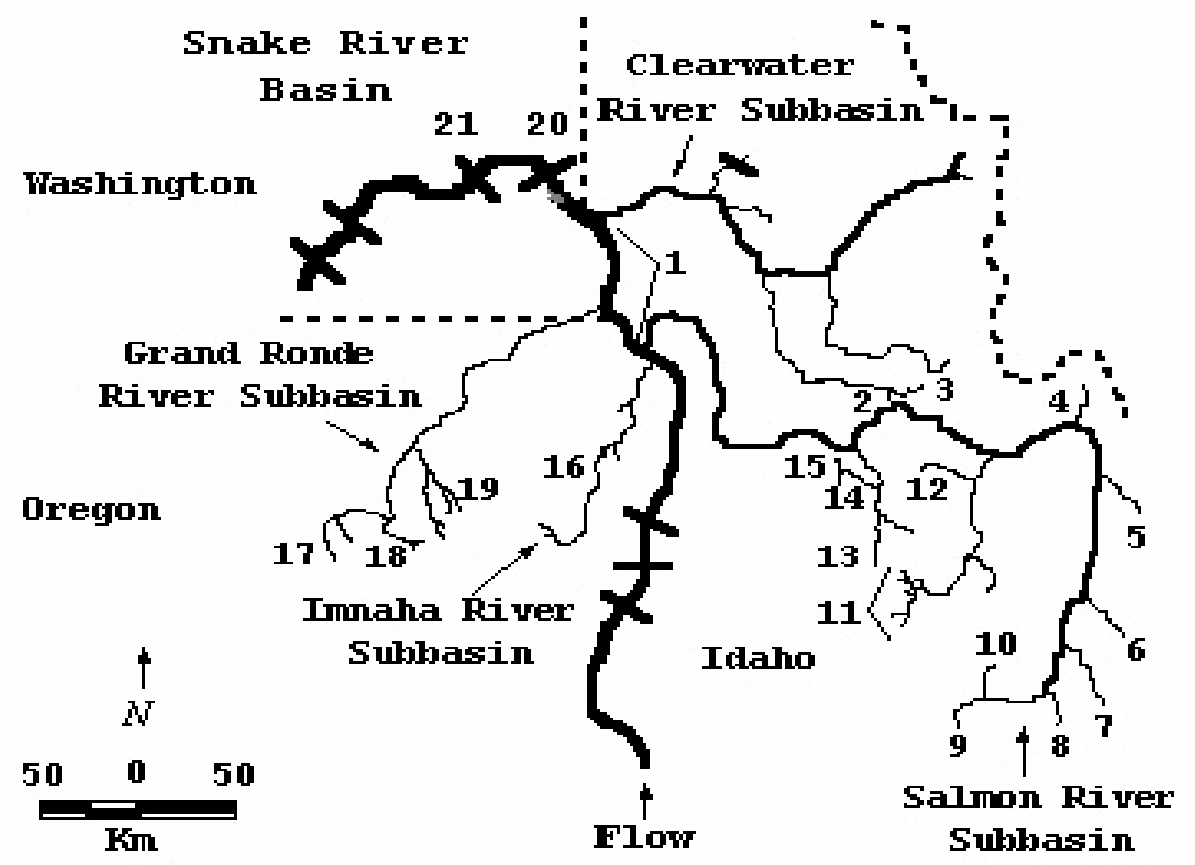

Figure 1.-The Snake River Basin including several of the subbasin tributaries where wild spring and summer* chinook salmon spawn, the beach seining area, and Lower Granite and Little Goose dams where PIT-tagged smolts were recaptured. ((1) Seining area, (2) Crooked River, (3) Red River, (4) North Fork Salmon River, (5) Lemhi River, (6) Pahsemeroi River, (7) West Fork Yankee Creek, (8) herd Creek, (9) East Fork Salmon River, (10) West Fork Salmon River, (11) Upper Salmon River including: Alturas Lake Creek, Valley Creek, Cape Horn Creek, Marsh Creek, Bear Valley Creek, Elk Creek, Sulphur Creek, (12) Big Creek, (13) South Fork Salmon River*, (14) Secesh River*, (15) Lake Creek*, (16) Imnaha River*, (17) Upper Grande Ronde River, (18) Catherine Creek, (19) Lostine River, (20) Lower Granite Dam (rkm 173), (21) Little Goose Dam (rkm 113)). 


\section{Methods}

We sampled wild subyearling chinook salmon parr in the Snake River from rkm 224 to rkm 291 (Figure 1) by beach seining as described by Connor et al. (1998) in 1993, 1994, 1996, 1997, and 1998. We began beach seining in April and continued into June or July until water temperatures exceeded $20^{\circ} \mathrm{C}$ and the catch was near zero. We tagged parr $\geq 60-\mathrm{mm}$ fork length with Passive Integrated Transponders (PIT tags) (Prentice et al. 1990). Details of parr handling and tagging were described by Connor et al. (1998). Tagged parr were released where they were captured to resume rearing and seaward migration.

A percentage of the PIT-tagged parr that survived rearing and early seaward migration were subsequently detected as smolts passing Lower Granite Dam in the fish bypass system as described by Connor et al. (2000). We recaptured a subsample of the detected smolts after they passed Lower Granite Dam by using a diversion device (Marsh et al. 1999) located in the fish bypass system of Lower Granite Dam (1993 and 1994) and Little Goose Dam (1996 to 1998) (Figure 1). In 1993, 1994, 1996, and 1997, we sampled scales, body muscle, heart, liver and eye tissues (Marshall et al. 2000) from each recaptured smolt. In 1998, we took scales and a pelvic fin clip.

We used scale pattern analysis (Koo 1967) to confirm that each recaptured wild chinook salmon smolt was a subyearling. The genetic lineage (i.e., fall or spring run) of each recaptured smolt was identified using allozyme multilocus genotypes with accuracy near $100 \%$ (Marshall et al. 2000) in 1993, 1994, 1996, and 1997. In 1998, the genetic lineage of each recaptured smolt was identified non-lethally using the dual primar product of a nuclear DNA marker (R. Rodriguez, U. S. Geological Survey, unpublished method). Run identification using the DNA marker is almost $100 \%$ reliable and provided nearly identical results when compared to identifications from allozyme genotypes (A. Marshall, Washington Department of Fish and Wildlife and C. Rasmussen, U. S. Geological Survey, unpublished data).

We recaptured PIT-tagged smolts 24-h/d from approximately May through September. Continuous daily sampling during these months was not possible because of logistical constraints and Endangered Species Act (ESA) Section 10 restrictions (USFWS 1988). We compared detections dates of all tagged smolts to the detection dates of the recaptured tagged smolts, and found that early and late migrating smolts were sometimes under-sampled. 
Therefore, we developed discriminant analysis models to classify run membership for tagged smolts that passed Lower Granite Dam, but were not recaptured and genetically identified.

We fit separate discriminant analysis models for each year $(N=5)$ using life history attribute data collected on genetically identified smolts. Variables included the date of initial capture and tagging (expressed as day of year), fork length at initial capture and tagging, rkm of initial capture and tagging, and date of passage at Lower Granite Dam (expressed as day of year). We fit test models using every combination of these variables, and by pooling and not pooling the covariance matrices (Johnson 1998).

We calculated both within-run and across-run classification accuracy for each test model using the cross-validation method (Johnson 1998). Within-run classification accuracy was the number of correct classifications divided by the number of recaptured fall or spring chinook salmon. Across-run classification accuracy was equal to the weighted average of the two values of within-run classification accuracy.

We selected the final discriminant analysis models based on across-run classification accuracy. We ran the final models to predict run membership for every PIT-tagged subyearling chinook salmon detected at Lower Granite dam that was not recaptured for genetic analysis. We combined fish of classified run membership (i.e., by discriminant analysis) with those genetically identified to obtain a data set of smolts detected at Lower Granite Dam throughout the sampling period. These groups provided more complete estimates of run composition and comparisons of early life history attributes than could be made using only genetically identified fish.

\section{Results}

We inserted PIT tags in 5,987 parr during the five years studied (Table 1). Detections of tagged smolts at Lower Granite Dam ranged from 97 to 379 (Table 1 ). We recaptured from 18.5 to 59.6\% of the tagged smolts after they were detected passing Lower Granite Dam (Table 1). The numbers of fall and spring chinook salmon that were genetically identified in each annual sample of recaptured smolts is given in the fifth column of Table 2 . 
Table 1.-The number of wild subyearling chinook salmon that were sampled along the snake River and PIT tagged, the number of PIT-tagged fish that were detected passing Lower Granite Dam, and the number and percentage detected fish that were recaptured after passing Lower Granite Dam, 1993, 1994, 1996, 1997, 1998.

\begin{tabular}{crrrr}
\hline & \multicolumn{3}{c}{ Number of fish } & Percent \\
\cline { 2 - 4 } Year & Tagged & Detected & Recaptured & $\begin{array}{c}\text { Pecaptured } \\
\text { recapturn }\end{array}$ \\
\hline 1993 & 1,252 & 234 & 116 & 49.6 \\
1994 & 2,337 & 193 & 115 & 59.6 \\
1996 & 413 & 126 & 26 & 20.6 \\
1997 & 553 & 97 & 25 & 25.8 \\
1998 & 1,432 & 379 & 70 & 18.5 \\
\hline
\end{tabular}

Table 2.-Classification of run membership using discriminant analysis models fit with genetically identified wild subyearling fall and spring/summer (abbreviated as spring) chinook salmon smolts that were recaptured after being detected at Lower Granite Dam, 1993, 1994, 1996-1998. Within- and across-run cross-validation classification accuracies (\%) are given by year.

\begin{tabular}{|c|c|c|c|c|c|c|}
\hline \multirow[b]{2}{*}{ Year } & \multirow{2}{*}{$\begin{array}{l}\text { Actual } \\
\text { run }\end{array}$} & \multicolumn{3}{|c|}{$\begin{array}{c}\text { Number classified into } \\
\text { each run }\end{array}$} & \multicolumn{2}{|c|}{ Classification accuracy (\% } \\
\hline & & Fall & Spring & Total & Within-run & Across-run \\
\hline 1993 & $\begin{array}{l}\text { Fall } \\
\text { Spring }\end{array}$ & $\begin{array}{l}37 \\
14\end{array}$ & $\begin{array}{l}12 \\
53\end{array}$ & $\begin{array}{l}49 \\
67\end{array}$ & $\begin{array}{l}75.5 \\
79.1\end{array}$ & 77.6 \\
\hline 1994 & $\begin{array}{l}\text { Fall } \\
\text { Spring }\end{array}$ & $\begin{array}{r}74 \\
7\end{array}$ & $\begin{array}{l}18 \\
16\end{array}$ & $\begin{array}{l}92 \\
23\end{array}$ & $\begin{array}{l}80.4 \\
69.6\end{array}$ & 78.3 \\
\hline 1996 & $\begin{array}{l}\text { Fall } \\
\text { Spring }\end{array}$ & $\begin{array}{r}19 \\
1\end{array}$ & $\begin{array}{l}3 \\
3\end{array}$ & $\begin{array}{r}22 \\
4\end{array}$ & $\begin{array}{l}86.4 \\
75.0\end{array}$ & 84.6 \\
\hline 1997 & $\begin{array}{l}\text { Fall } \\
\text { Spring }\end{array}$ & $\begin{array}{r}10 \\
2\end{array}$ & $\begin{array}{l}4 \\
9\end{array}$ & $\begin{array}{l}14 \\
11\end{array}$ & $\begin{array}{l}71.4 \\
81.8\end{array}$ & 76.0 \\
\hline 1998 & $\begin{array}{l}\text { Fall } \\
\text { Spring }\end{array}$ & $\begin{array}{r}29 \\
8\end{array}$ & $\begin{array}{r}9 \\
24\end{array}$ & $\begin{array}{l}38 \\
32\end{array}$ & $\begin{array}{l}76.3 \\
75.0\end{array}$ & 75.7 \\
\hline
\end{tabular}


When using the life history attributes of the genetically identified smolts to fit the five discriminant analysis models, we found that across-run classification accuracy averaged 78.4\% and ranged from 75.7 to $84.6 \%$ (Table 2). Date of initial capture and tagging, fork length at initial capture and tagging, and date of passage at Lower Granite Dam were used in the 1993 and 1994 models to classify the smolts. For the 1996 model, classification was based on fork length at initial capture and tagging, and date of passage at Lower Granite Dam. Date of passage at Lower Granite Dam was used in the 1997 model to classify smolts. In the 1998 model, classification was based on rkm of initial capture and tagging, and date of passage at Lower Granite Dam.

After combining the smolts of classified-run origin with those genetically identified, the total number of smolts available for estimating run composition and comparing early life history attributes was 1,029 of which 760 (73.9\%) were fall chinook salmon and 269 (26.1\%) were spring chinook salmon. Annual run composition ranged from 55.6 to $84.9 \%$ fall chinook salmon, and 15.1 to $44.4 \%$ spring chinook salmon (Table 3 ).

Table 3.-The percentages of PIT-tagged wild subyearling fall and spring/summer (abbreviated as spring) chinook salmon (i.e., run composition) detected passing Lower Granite Dam, 1993, 1994, 1996-1998. Detected smolts include fish of classified run membership (i.e., using discriminant analysis) and those that were genetically identified.

Run composition (\%)

\begin{tabular}{cccc} 
& $\begin{array}{c}\text { Number of smolts } \\
\text { Year }\end{array}$ & Fall & Spring \\
\cline { 3 - 4 } 1993 & 234 & 55.6 & 44.4 \\
1994 & 193 & 76.2 & 23.8 \\
1996 & 126 & 84.9 & 15.1 \\
1997 & 97 & 67.0 & 33.0 \\
1998 & 379 & 82.1 & 17.9 \\
\hline
\end{tabular}


Early life history, based on the attributes we measured annually, proceeded on a slightly earlier time schedule for spring chinook salmon than for fall chinook salmon (Figure 2). Fall chinook salmon were captured and tagged as parr rearing along the Snake River later $(N=5$; grand median $=$ day 160$)$ than the spring chinook salmon $(N=5 ;$ grand median $=$ day 155). Fall chinook salmon parr were consistently smaller ( $N=5$; grand median $=73 \mathrm{~mm}$ ) when captured and tagged than spring chinook salmon parr $(N=5 ;$ grand median $=85 \mathrm{~mm})$. There was no consistent pattern among years for rkm of capture. Fall chinook salmon smolts passed Lower Granite Dam later ( $N=5$; grand median $=$ day 202) than spring chinook salmon smolts $(N=5$; grand median $=$ day 187).

\section{Discussion}

We were able to use genetic identification methods on subsamples of smolts to provide data for fitting discriminant analysis models that classified subyearling chinook salmon run membership with accuracy ranging from 75.7 to $84.6 \%$. Classifying subyearling chinook salmon run membership is difficult when using early life history attributes or even body morphology which has been used in other studies of juvenile anadromous salmonids (Carl and Healey 1984; Taylor and McPhail 1985; Taylor 1986; Swain and Holtby 1989). Tiffan et al. (2000) used discriminant analysis models fit from body morphology traits and found that subyearling spring chinook salmon smolts recaptured at Lower Granite Dam were mis-classified as subyearling fall chinook salmon an average of $74 \%$ of the time. We conclude that the discriminant analysis model we fit classified run membership for wild subyearling chinook salmon smolts with acceptable accuracy.

After completing discriminant analysis and pooling classified and genetically identified fish, we found that spring chinook salmon were captured and tagged as parr earlier and were larger than fall chinook salmon parr. We believe the explanation for these differences is that spring chinook salmon fry emerged earlier than fall chinook salmon fry and grew while moving from upstream natal areas. Spring chinook salmon smolts were also detected passing Lower Granite Dam earlier than fall chinook salmon smolts, perhaps because spring chinook salmon parr reached a threshold size for seaward migration (Folmar and Dickhoff 1980; Wedemeyer et al. 1980) earlier than fall chinook salmon parr. Others studying juvenile anadromous salmonids have 

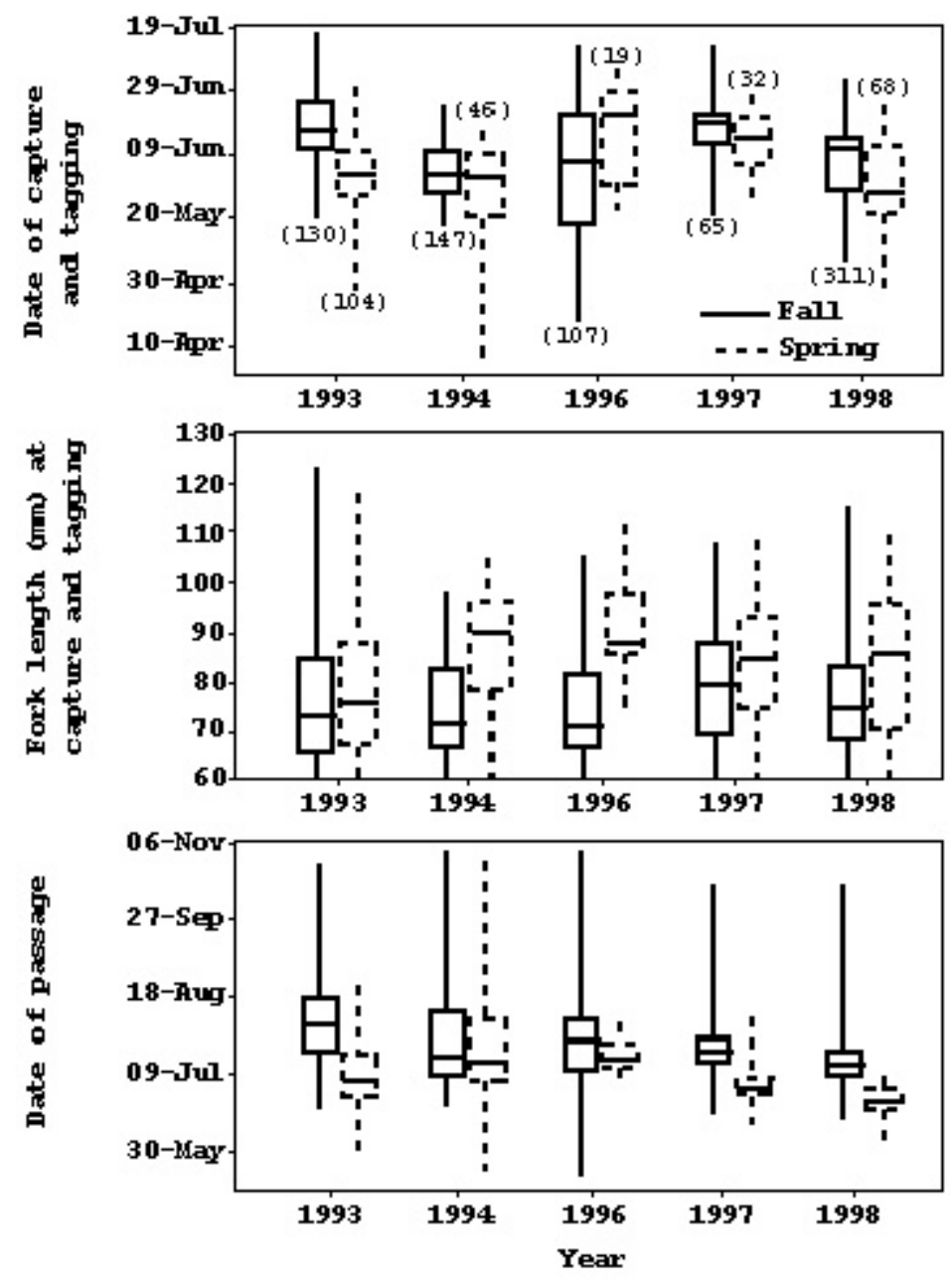

Figure 2.-Date of initial capture and tagging (Top), fork length at initial capture and tagging (Middle), and date of passage at Lower Granite Dam (Bottom) for PIT-tagged wild subyearling fall and spring chinook salmon ( $N$ is given in parentheses at top), 1993, 1994, 1996-1998. The range is shown by the vertical lines, the top of each box is the $75^{\text {th }}$ percentile, the horizontal line in the box is the median, and bottom of each box is the $25^{\text {th }}$ percentile. 
documented differences in early life history attributes that resulted from time of fry emergence (Lister and Genoe 1970; Everest and Chapman 1972).

The results in this paper have an important management implication relative to monitoring recovery of the snake River fall chinook salmon population listed for protection under the ESA in 1992 (NMFS 1992). Although the proportion of snake River spring chinook salmon that migrate to the sea as subyearlings is a small fraction of the total spring chinook salmon smolt number, they can make up a large part of the subyearling migration, especially in years when small numbers of fall chinook salmon are present. The wide variability observed in run composition of PIT-tagged smolts emphasizes that subyearling chinook salmon passage indices at Lower Granite Dam cannot be used alone to index fall chinook salmon smolt abundance and passage timing. If used without knowledge of subyearling spring chinook salmon smolt presence, fall chinook salmon smolt abundance would be overestimated and timing of fall chinook salmon smolt passage would appear to be earlier and more protracted than is the case. 


\section{References}

Bjornn, T.C. 1971. Trout and salmon movement in two streams as related to temperature, food, stream flow, cover, and population density. Transactions of the American Fisheries Society $100: 423-438$.

Carl, L. M., and M. C. Healey. 1984. Differences in enzyme frequency and body morphology among three juvenile life history types of chinook salmon (Oncorhynchus tshawytscha) in the Nanaimo River, British Columbia. Canadian Journal of Fisheries and Aquatic Sciences 41:1070-1077.

Chapman, D. W., and T. C. Bjornn. 1969. Distribution of salmonids in streams with special reference to food and feeding. Pages 153-176 in T. G. Northcote, editor. Symposium on salmon and trout streams. University of British Columbia, Vancouver.

Connor, W. P., H. L. Burge, and D. H. Bennett. 1998. Detection of subyearling chinook salmon at a snake River dam: Implications for summer flow augmentation. North American Journal of Fisheries Management 18:530-536.

Connor, W. P., R. K. Steinhorst, and H. L. Burge. 2000. Forecasting survival and passage for migratory juvenile salmonids. North American Journal of Fisheries Management $20: 651-660$.

Everest, F. H., and D. W. Chapman. 1972. Habitat selection and spatial interaction by juvenile chinook salmon and steelhead trout in streams. Journal of the Fisheries Research Board of Canada 29:91-100.

Groves, P. A., and J. A. Chandler. 1999. Spawning habitat used by fall chinook salmon in the Snake River. North American Journal of Fisheries Management 19:912-922.

Healey, M. C. 1991. Life history of chinook salmon (Oncorhynchus tshawytscha). Pages 312 to 393, in C. Groot and L.Margolis, editors, Pacific salmon life histories. UBC press, Vancouver, British Columbia.

Howell, P., and several coauthors. 1984. Stock assessment of Columbia River salmonids volume 1: chinook, coho, chum, and sockeye stock summaries. Final report for contract DE- 
AI79-84BP12737 to Bonneville Power Administration, Portland, Oregon.

Johnson, D. E. 1998. Applied multivariate methods for data analysis. Brooks/Cole Publishing Company, Pacific Grove, California.

Koo, T. S. Y. 1967. Objective studies of the scales of tshawytscha (Walbaum). U. S. Fish and Wildlife Service Fishery Bulletin 66:165-180.

Lister, D. B., and H. S. Genoe. 1970. Stream habitat utilization by cohabiting underyearlings of chinook (Oncorhychus tshawytscha) and coho (Oncorhynchus kisutch) salmon in the Big Qualicum River, British Columbia. Journal of the Fisheries Research Board of Canada 27:1215-1224.

Marsh, D. M., G. M. Matthews, S. Achord, T. E. Ruehle, and B. P. Sandford. 1999. Diversion of salmonid smolts tagged with passive integrated transponders from an untagged population passing through a juvenile collection system. North American Journal of Fisheries Management 19:1142-1146.

Marshall, A.R., H.L. Blankenship, and W.P. Connor. 2000. Genetic characterization of naturally spawned Snake River fall-run chinook salmon. Transactions of the American Fisheries Society 129:680-698.

NMFS (National Marine Fisheries Service). 1992. Threatened status for Snake River spring chinook salmon, threatened status for Snake River fall chinook salmon. Federal Register 57:78(22 April 1992):14,653-14,663.

Prentice, E. F., T. A. Flagg, and C. S. McCutcheon. 1990. Feasibility of using implantable passive integrated transponders (PIT) tags in salmonids. Pages 317-322 in $\mathrm{N}$. C. Parker, A. E. Giorgi, R. C. Heidinger, D. B. Jester, E. D. Prince, and G. A. Winans, editors. Fish-Marking techniques. American Fisheries Society, Symposium 7, Bethesda, Maryland.

Swain, D.P., and L. B. Holtby. 1989. Differences in morphology and behavior between juvenile coho salmon Oncorhynchus kisutch rearing in a lake and in its tributary stream. Canadian Journal of Fisheries and Aquatic Sciences 46:14061414 . 
Taylor, E. B., and J. D. McPhail. 1985. Variation in body morphology among British Columbia populations of coho salmon, Oncorhynchus kisutch. Canadian Journal of Fisheries and Aquatic Sciences 42:2020-2028.

Taylor, E. B. 1986. Differences in morphology between wild and hatchery populations of juvenile coho salmon. The Progressive Fish Culturist 48:171-176.

Tiffan, K. F., D. W. Rondorf, R. D. Garland, and P. A. Verhey. 2000. Identification of juvenile fall versus spring chinook salmon migrating through the lower snake River based on body morphology. Transactions of the American Fisheries Society 129:1272-1278.

USFWS (U. S. Fish and Wildlife Service). 1988. Endangered Species Act of 1973 as amended through the 100th Congress. United States Department of the Interior, Washington, D.C.

Wedemeyer, G. A., R. L. Saunders, and W. Craig Clarke. 1980. Environmental factors affecting smoltification and early marine survival of anadromous salmonids. Marine Fisheries Review $42(6): 3-14$. 


\title{
CHAPTER TWO
}

The Role of Rapid Growth on Seaward Migration of Wild Subyearling Spring Chinook Salmon in the Snake River

\author{
by \\ William P. Connor \\ U. S. Fish and Wildlife Service \\ P.O. Box 18, Ahsahka, Idaho 83520, USA \\ Theodore C. Bjornn \\ U. S. Geological Survey \\ Idaho Cooperative Fish and Wildlife Research Unit \\ University of Idaho, Moscow, Idaho 83843, USA \\ Howard L. Burge \\ U. S. Fish and Wildlife Service \\ P.O. Box 18, Ahsahka, Idaho 83520, USA \\ Anne R. Marshall \\ Washington Department of Fish and Wildlife \\ 600 Capitol Way North, Olympia, Washington 98501, USA
}




\section{Introduction}

Juvenile anadromous salmonids have wide intra- and interspecific variability in age at seaward migration. Growth during spring is important to the process of smoltification and helps determine age at seaward migration (Folmar and Dickhoff 1980; Wedemeyer et al. 1980; Dickhoff et al. 1997; Beckman and Dickhoff 1998; Beckman et al. 1999). One measure of the potential of a stream to provide the growth necessary to initiate seaward migration is called growth opportunity. Metcalfe and Thorpe (1990) developed a growth opportunity index based on mean air temperature (used as a surrogate for water temperature) and photoperiod that explained $82 \%$ of the observed variability in age at smolting for wild Atlantic salmon Salmo salar. Taylor (1990) analyzed data from 160 chinook salmon Oncorhynchus tshawytscha populations ranging from California to Alaska, and he showed that areas with low growth opportunity tended to produce juveniles with "stream-type" (Healey 1991) early life histories.

In the Snake River basin, spring/summer (hereafter, spring) chinook salmon typically have a stream-type life history. Adult spring chinook salmon migrate upstream through the Snake River during spring and early summer to high elevation cool-water tributaries of the Clearwater River, Grande Ronde River, Salmon River, and Imnaha River subbasins (Figure 1) where they spawn during August and September. The fry emerge primarily from late January through early May (Howell et al. 1984). Bjornn (1971) found that juvenile spring chinook salmon in tributaries of the Salmon River dispersed from spawning areas as fry (less than 50 $\mathrm{mm}$ fork length) soon after emergence, as subyearlings (70 to 120 $\mathrm{mm}$ ) in the fall and winter after their first summer, and as yearling smolts (80 to $130 \mathrm{~mm}$ ) in spring. The majority of juvenile spring chinook salmon migrate to the sea primarily as yearling smolts during spring after overwintering in larger order streams such as the Salmon River (Chapman and Bjornn 1969). Achord et al. (1996) found that passage of wild yearling Snake River spring chinook salmon at Lower Granite Dam (Figure 1) peaked in April, and tailed off into July.

When genetically characterizing "ocean-type" (Healey 1991) wild fall chinook salmon using subyearling smolts recaptured at Lower Granite Dam from 1991 to 1995, Marshall et al. (2000) unexpectedly found that 5 to $63 \%$ of the smolts were wild subyearling spring chinook salmon which were genotypically similar to baseline samples for the stream-type spring chinook salmon stocks in the Snake River basin. These findings raised 


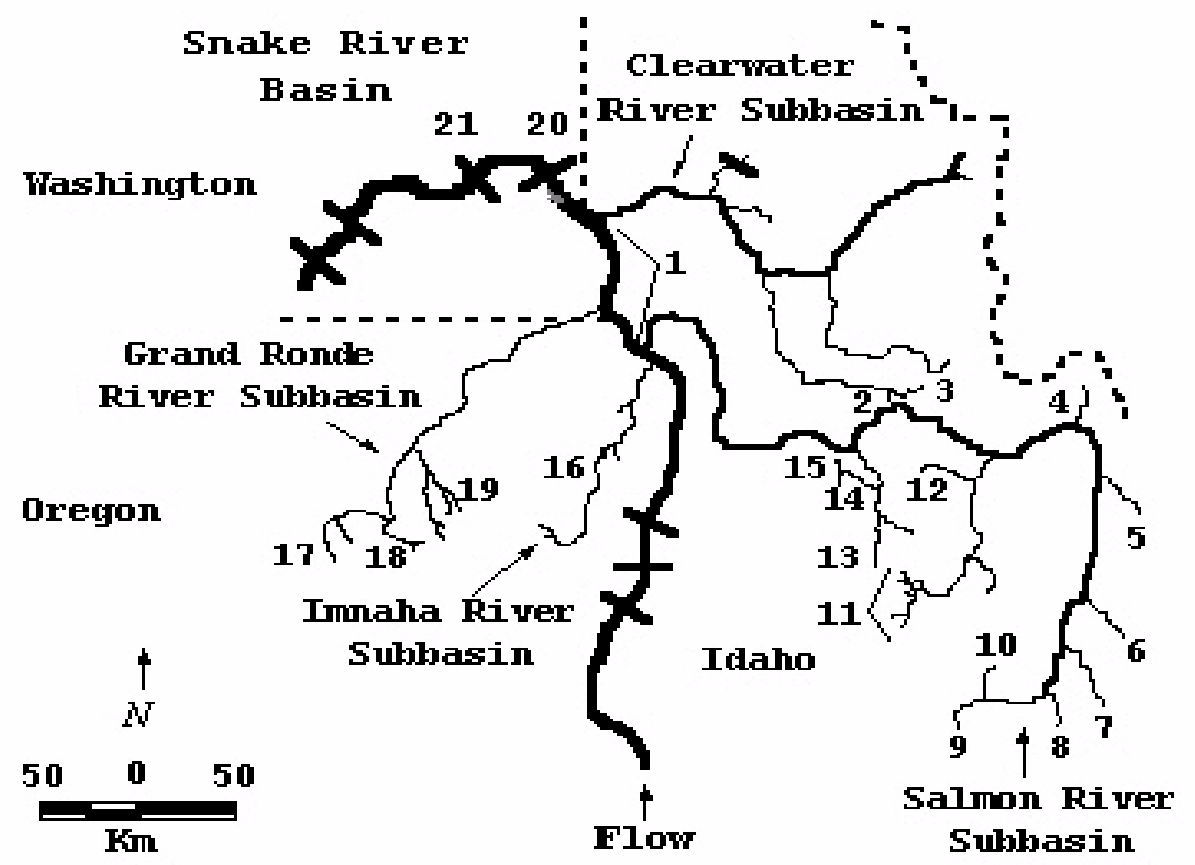

Figure 1.-The Snake River Basin including several of the subbasin tributaries where wild spring and summer* chinook salmon spawn, the beach seining area, and Lower Granite and Little Goose dams where PIT-tagged smolts were recaptured. ((1) Seining area, (2) Crooked River, (3) Red River, (4) North Fork Salmon River, (5) Lemhi River, (6) Pahsemeroi River, (7) West Fork Yankee Creek, (8) herd Creek, (9) East Fork Salmon River, (10) West Fork Salmon River, (11) Upper Salmon River including: Alturas Lake Creek, Valley Creek, Cape Horn Creek, Marsh Creek, Bear Valley Creek, Elk Creek, Sulphur Creek, (12) Big Creek, (13) South Fork Salmon River*, (14) Secesh River*, (15) Lake Creek*, (16) Imnaha River*, (17) Upper Grande Ronde River, (18) Catherine Creek, (19) Lostine River, (20) Lower Granite Dam (rkm 173), (21) Little Goose Dam (rkm 113)). 
the question, why do some wild spring chinook salmon migrate seaward one year earlier than normal? Researchers have shown that accelerated growth increases indices of smoltification and can promote early seaward migration of spring chinook salmon reared in hatcheries, artificial streams, or laboratories (Hart et al. 1981; Ewing et al. 1980, 1984; Beckman and Dickhoff 1998), but to our knowledge early seaward migration as related to growth has not been described for spring chinook salmon in the wild. In this note, we present growth information that helps to explain why a small fraction of the wild snake River spring chinook salmon population migrates seaward one year earlier than normal.

\section{Methods}

We collected wild subyearling chinook salmon parr in the Snake River from rkm 224 to rkm 291 (Figure 1) by beach seining as described by Connor et al. (1998) in 1993, 1994, 1997, and 1998. We began beach seining in April and continued into June or July until water temperatures exceeded $20^{\circ} \mathrm{C}$ and the catch was near zero. We tagged parr $\geq 60-\mathrm{mm}$ fork length with Passive Integrated Transponders (PIT tags) (Prentice et al. 1990). Details of parr handling and tagging were described by Connor et al. (1998). Tagged parr were released where they were captured to resume rearing.

Subsamples of our tagged parr that survived rearing and early seaward migration were detected as smolts passing Lower Granite Dam in the fish bypass system as described by (Connor et al. 2000). We recaptured a subsample of the detected smolts in the bypass system at Lower Granite Dam in 1993 and 1994 by using a diversion device (Marsh et al. 1999). In 1997 and 1998, we recaptured smolts in the bypass system at Little Goose Dam (Figure 1). In 1993, 1994, and 1997, we measured fork length (mm) and then sampled scales, body muscle, heart, liver and eye tissues (Marshall et al. 2000) from each recaptured smolt. In 1998, we measured fork length then took scales and a pelvic fin clip.

Two experienced scale pattern analysts used methods described by Koo (1967) to confirm that each recaptured wild chinook salmon smolt was a subyearling. In 1993, 1994, and 1997, the genetic lineage (i.e., fall or spring run) of each recaptured smolt was identified using allozyme multilocus genotypes with accuracy near 100\% (Marshall et al. 2000). In 1998, the genetic lineage of each recaptured smolt was 
identified non-lethally using the dual primar product of a nuclear DNA marker (R. Rodriguez, U. S. Geological Survey, unpublished method). Run identification using the DNA marker is almost $100 \%$ reliable, and it provided nearly identical results when compared to identifications from allozyme genotypes (A. Marshall, Washington Department of Fish and Wildlife and $C$. Rasmussen, U. S. Geological Survey, unpublished data).

For wild subyearlings genetically identified as spring chinook salmon, we calculated absolute growth rates during early seaward migration as: fork length at recapture minus fork length at initial capture divided by the number of days between initial capture and recapture.

\section{Results}

We captured, PIT tagged and released from 413 to 2,337 wild subyearling chinook salmon parr during 1993, 1994, 1997, and 1998. The total number of tagged smolts detected passing Lower Granite Dam was 234 in 1993 and 193 in 1994, of which 114 (48.7\%) and 115 (59.6\%) were recaptured. The total number of tagged smolts detected passing Little Goose Dam was 79 in 1997 and 407 in 1998 of which 57 (72.2\%) and 137 (33.7\%) were recaptured. Genetic analyses indicated that the percentage of spring chinook salmon in the samples of wild subyearlings recaptured at the dams was $57.9 \%$ in 1993, 20.0\% in 1994, 47.4\% in 1997, and 45.3\% in 1998 .

Wild subyearlings genetically identified as spring chinook salmon were initially captured, PIT tagged, and released along the Snake River from 28-April to 29-June (Table 1). Mean fork length of wild subyearling spring chinook salmon when they were initially captured, PIT tagged, and released along the snake River ranged from 78.4 to $87.2 \mathrm{~mm}$ (Table 1). Date of passage for PIT-tagged wild subyearling spring chinook salmon ranged from 17-June to 25-August at Lower Granite Dam, and from 17-May to 22-August at Little Goose Dam (Table 1). Mean fork lengths of PIT-tagged wild subyearling spring chinook salmon recaptured at Lower Granite Dam were 122.3 and $137.0 \mathrm{~mm}$, and 127.9 and 135.1 mm at Little Goose Dam (Table 1). Mean absolute growth rate during early seaward migration ranged from 1.0 to $1.5 \mathrm{~mm} / \mathrm{d}$ (Table 1). 
Table 1.-Ranges of initial capture dates and mean fork lengths (FL; $\mathrm{mm}$ ) for wild subyearling spring chinook salmon PIT tagged as parr rearing along the snake River, and the ranges of dates and mean fork lengths for the same fish recaptured as smolts at Lower Granite Dam (1993 and 1994) or Little Goose Dam (1997 and 1998). Absolute growth rates during early seaward migration $(\mathrm{mm} / \mathrm{d})$ were calculated for every fish and then averaged within each year.

\begin{tabular}{|c|c|c|c|c|c|c|c|c|}
\hline \multirow[b]{2}{*}{ Year } & \multirow[b]{2}{*}{$\mathrm{N}$} & \multicolumn{3}{|c|}{ Initial capture } & \multicolumn{3}{|c|}{ Recapture } & \multirow{2}{*}{$\begin{array}{l}\text { gan absolute } \\
\text { growth rate } \\
(\mathrm{mm} / \mathrm{d}+\mathrm{SD})\end{array}$} \\
\hline & & $\begin{array}{l}\text { Dat } \\
\text { ran }\end{array}$ & & $\begin{array}{l}\text { Mean FL } \\
\text { (range) }\end{array}$ & & $\begin{array}{l}\text { ate } \\
\text { ange }\end{array}$ & $\begin{array}{c}\text { Mean FL } \\
\text { (range) }\end{array}$ & \\
\hline 1993 & 65 & 18-May & 29-Jun & $\begin{array}{c}78.4 \\
(60-117)\end{array}$ & 17-Jun & 25-Aug & $\begin{array}{c}122.3 \\
(71-166)\end{array}$ & $1 \cdot 3+0 \cdot 327$ \\
\hline 1994 & 23 & 05-May & 15-Jun & $\begin{array}{c}87.2 \\
(60-104)\end{array}$ & 23-Jun & 06-Aug & $\begin{array}{c}137.0 \\
(96-176)\end{array}$ & $1.0 \pm 0.355$ \\
\hline 1997 & 27 & 06-May & 25-Jun & $\begin{array}{c}86.0 \\
(66-108)\end{array}$ & 17-May & 22-Aug & $\begin{array}{c}127.9 \\
(107-160)\end{array}$ & $1.3 \pm 0.225$ \\
\hline 1998 & 62 & $28-A p r$ & 24-Jun & $\begin{array}{c}85.8 \\
(60-110) \\
\end{array}$ & $22-J u n$ & $21-J u 1$ & $\begin{array}{c}135.1 \\
(108-153)\end{array}$ & $1.5 \pm 0.246$ \\
\hline
\end{tabular}




\section{Discussion}

We found that wild subyearling spring chinook salmon parr rearing along the shorelines of the snake River attained mean fork lengths that ranged from 78.4 to $87.2 \mathrm{~mm}$ during spring and early summer. We also found that mean absolute growth was rapid (range 1.0 to $1.5 \mathrm{~mm} / \mathrm{d}$ ) during early seaward migration, and that wild subyearling spring chinook salmon smolts averaged from 122 to $137 \mathrm{~mm}$ during spring and early summer. In the Lemhi River of the Salmon River subbasin, it took until early fall and winter for wild spring chinook salmon to grow to fork lengths ranging from 70 to $130 \mathrm{~mm}$ (Bjornn 1971). In Bear Valley Creek of the Salmon River subbasin, wild subyearling spring chinook salmon averaged only $39 \mathrm{~mm}$ total length in July (Horner 1978). Achord et al. (1996) collected wild subyearling spring chinook salmon in 19 small order tributaries in the Clearwater River, Grande Ronde River, Salmon River, and Imnaha River subbasins during August and September and the fork lengths of the fish ranged from 63 to $83 \mathrm{~mm}$. These results show that wild subyearling spring chinook salmon fry that disperse downstream into larger order streams, and eventually into the snake River, grow much faster than those that rear in close vicinity to spawning areas.

Growth opportunity may be higher in the snake River and its larger order tributaries than in headwater streams because lower order streams are generally more shaded, have cooler less stable water temperature regimes, and are less productive (Vannote et al. 1980). There are two ways high growth opportunity may

affect age at seaward migration. First, there is evidence for a critical size for smoltification (Folmar and Dickhoff 1980; Wedemeyer et al. 1980). Hatchery-reared spring chinook salmon released in a tributary of the Salmon River, migrated downstream within days of release in June when they averaged $75 \mathrm{~mm}$ or more fork length, but few 55-mm fish migrated downstream (Bjornn 1978). Experiments conducted with subyearling spring chinook salmon in an artificial stream in Oregon showed that larger fish migrated before smaller fish (Ewing et al. 1984). The wild subyearling spring chinook salmon we studied may have migrated seaward one year early because the rearing environments of the larger order streams they encountered en route to the snake River, and the rearing environment of the snake River, allowed them to grow to a critical size by early summer.

The second way that high growth opportunity may affect age at seaward migration is by promoting rapid growth during a critical period of time. Dickhoff et al. (1997) proposed that releases of plasma growth hormones, associated with rapid 
growth, integrate physiological responses with environmental cues and facilitate successful smoltification. Beckman and Dickhoff (1998) produced preliminary results that suggested age at smolting decreased as growth rate of subyearling spring chinook salmon increased, and they provided an example of fast growing wild spring chinook salmon that migrated seaward as subyearlings. These two recent studies, and others (Folmar and Dickhoff 1980; Wedemeyer et al. 1980; Ewing et al. 1984; Thorpe 1989; Metcalfe and Thorpe 1990; Taylor 1990), indicate that fast growing parr may smolt and migrate seaward earlier in life than slow growing parr.

We conclude that wild subyearling spring chinook salmon that disperse from natal spawning areas downstream into the Snake River grow more rapidly than their tributary rearing counterparts. This increased growth is sustained during early seaward migration and it helps to explain why some wild spring chinook salmon migrate seaward as subyearlings, while others from the same cohort migrate seaward as yearlings. 


\section{References}

Achord, S., G. M. Matthews, O. W. Johnson, and D. M. Marsh. 1996. Use of passive integrated transponder (PIT) tags to monitor migration timing of snake River chinook salmon smolts. North American Journal of Fisheries Management $16: 302-313$.

Beckman, B. R., and several coauthors. 1999. Growth, smoltification and smolt-to-adult return of spring chinook salmon from hatcheries on the Deschutes River, Oregon. Transactions of the American Fisheries Society 128:11251150 .

Beckman, B. R., and W. W. Dickhoff. 1998. Plasticity of smolting in spring chinook salmon: relation to growth and insulin-like growth factor-I. Journal of Fish Biology $53: 808-826$.

Bjornn, T. C. 1971. Trout and salmon movement in two streams as related to temperature, food, stream flow, cover, and population density. Transactions of the American Fisheries Society $100: 423-438$.

Bjornn, T.C. 1978. Survival, production, and yield of trout and chinook salmon in the Lemhi River, Idaho. Bulletin 27, Forest, Wildlife, and Range Experiment station, University of Idaho, Moscow.

Chapman, D. W., and T. C. Bjornn. 1969. Distribution of salmonids in streams with special reference to food and feeding. Pages 153-176 in T. G. Northcote, editor. Symposium on salmon and trout streams. University of British Columbia, Vancouver.

Connor, W. P., H. L. Burge, and D. H. Bennett. 1998. Detection of subyearling chinook salmon at a snake River dam: Implications for summer flow augmentation. North American Journal of Fisheries Management 18:530-536.

Connor, W. P., R. K. Steinhorst, and H. L. Burge. 2000. Forecasting survival and passage for migratory juvenile salmonids. North American Journal of Fisheries Management $20: 651-660$. 
Dickhoff, W. W., B. R. Beckman, D. A. Larsen, C. Duan, and S. Moriyama. 1997. The role of growth in endocrine regulation of salmon smoltification. Fish Physiology and Biochemistry 17: 231-236.

Ewing, R. D., H. J. Pribble, S. L. Johnson, C. A. Futish, and J. Diamond, and J. A. Lichatowich. 1980. Influence of size, growth rate, and photoperiod cyclic changes in gill (Na+K)ATPase activity in chinook salmon (Oncorhynchus tshawytscha). Canadian Journal of Fisheries and Aquatic Sciences 37:600-605.

Ewing, R. D., C. E. Hart, C. A. Futish, and G. Concannon. 1984. Effects of size and time of release on seaward migration of spring chinook salmon, Oncorhynchus tshawytscha. Fishery Bulletin 82:157-164.

Folmar, L. C., and W. W. Dickhoff. 1980. The parr-smolt transformation (smoltification) and seawater adaptation in salmonids a review of selected literature. Aquaculture $21: 1-37$.

Hart, C. E., G. Concannon, C. A. Futish, and R. D. Ewing. 1981. Seaward migration and gill ( $\mathrm{Na}+\mathrm{K})$-ATPase activity of spring chinook salmon in an artificial stream. Transactions of the American Fisheries Society 110:44-50.

Healey, M. C. 1991. Life history of chinook salmon(Oncorhynchus thawytscha). Pages 312 to 393, in C. Groot and L. Margolis, editors, Pacific salmon life histories. UBC press, Vancouver, British Columbia.

Howell, P., and several coauthors. 1984. Stock assessment of Columbia River salmonids volume 1: chinook, coho, chum, and sockeye stock summaries. Final report for contract DEAI79-84BP12737 to Bonneville Power Administration, Portland, Oregon.

Horner, N. 1978. Survival, densities and behavior of salmonid fry in streams in relation to fish predation. Master's Thesis, University of Idaho, Moscow, Idaho.

Koo, T. S. Y. 1967. Objective studies of the scales of tshawytscha (Walbaum). U. S. Fish and Wildlife Service Fishery Bulletin 66:165-180. 
Marsh, D. M., G. M. Matthews, S. Achord, T. E. Ruehle, and B. P. Sandford. 1999. Diversion of salmonid smolts tagged with Passive Integrated Transponders from an untagged population passing through a juvenile collection system. North American Journal of Fisheries Management 19:1142-1146. 
Marshall, A. R., H. L. Blankenship, and W. P. Connor. 2000. Genetic characterization of naturally spawned Snake River fall-run chinook salmon. Transactions of the American Fisheries Society 129:680-698.

Metcalfe N. B., and J. E. Thorpe. 1990. Determinants of geographical variation in the age at seaward-migrating salmon Salmo salar. Journal of Animal Ecology 59:135-145.

Prentice, E. F., T. A. Flagg, and C. S. McCutcheon. 1990. Feasibility of using implantable passive integrated transponders (PIT) tags in salmonids. Pages 317-322 in $\mathrm{N}$. C. Parker, A. E. Giorgi, R. C. Heidinger, D. B. Jester, E. D. Prince, and G. A. Winans, editors. Fish-Marking techniques. American Fisheries Society, Symposium 7, Bethesda, Maryland.

Taylor, E. B. 1990. Environmental correlates of life-history variation in juvenile chinook salmon, Oncorhynchus tshawytscha (Walbaum). Journal of Fish Biology 37:1-17.

Thorpe, J.E. 1989. Developmental variation in salmonid populations. Journal of Fish Biology 35:295-303.

Vannote, R. L., G. W. Minshall, K. W. Cummins, J. R. Sedell, and C. E. Cushing. 1980. The river continuum concept. Canadian Journal of Fisheries and Aquatic Sciences 37:130137 .

Wedemeyer, G. A., R. L. Saunders, and W. Craig Clarke. 1980. Environmental factors affecting smoltification and early marine survival of anadromous salmonids. Marine Fisheries Review $42(6): 3-14$. 
CHAPTER THREE

Snake River Fall Chinook Salmon Early Life History and Growth as Affected by Dams

by

William P. Connor, Howard L. Burge, Russell Waitt, and Aaron P. Garcia

U. S. Fish and Wildlife Service

P.O. Box 18, Ahsahka, Idaho 83520, USA

Theodore C. Bjornn

U. S. Geological Survey

Idaho Cooperative Fish and Wildlife Research Unit University of Idaho, Moscow, Idaho 83843, USA 


\section{Introduction}

Construction and operation of dams has affected populations of anadromous salmonids in North America. Three effects of dams are germane to the present paper. First, dams can eliminate passage to spawning areas (e.g., Moffitt et al. 1982; Wunderlich et al. 1994; Kondolf et al. 1996). In such cases, the population can be extirpated or spawning shifts from historic core areas to margins of the historic range.

The water temperature regime of a river downstream of a dam can change from pre-dam conditions (e.g., Hall and Van Den Avyle 1986). Regulated rivers can be warmer during fall, warm slower during the late winter and spring, and be cooler during the summer months because reservoirs respond slowly to changes in solar radiation and can release water that is warmer or colder than stream inflow. Releases of water from the hypolimnion of reservoirs can cool the water of historically warm rivers, or warm the water of historically cool rivers. Releases of reservoir water into rivers can therefore change developmental rates of anadromous salmonid eggs, the progression of early life history events, and juvenile growth rates.

Dams also impound rivers thereby reducing water velocity. Park (1969) and Raymond (1979) proposed that decreased water velocities in reservoirs delayed downstream migration by steelhead Oncorhynchus mykiss and chinook salmon 0 . tshawytscha smolts in the Columbia and Snake River basins by at least $30 \mathrm{~d}$. An extended period of freshwater residence of smolts is therefore a third affect dams can have on juvenile anadromous salmonids.

By 1964, the ongoing construction of Brownlee, Oxbow, and Hells Canyon dams (hereafter, the Hells Canyon Complex) had blocked access to the historic production area for Snake River fall chinook salmon located near Marsing, Idaho (Figure 1). Fall chinook salmon presently spawn from October to December (Groves and Chandler 1999) primarily in a 173-km reach of the Snake River downstream of Hells Canyon Complex, and a 64-km reach of the lower Clearwater River downstream of Dworshak Dam (Idaho Power Company, Nez Perce Tribe, U. S. Fish and Wildlife Service, unpublished data) (Figure 1). Consequently, snake River fall chinook salmon egg incubation, parr rearing, and growth are influenced by water temperatures regulated by dams. Subyearling fall chinook salmon smolts must also pass up to eight mainstem reservoirs and dams (Figure 1 ) to reach the sea. 


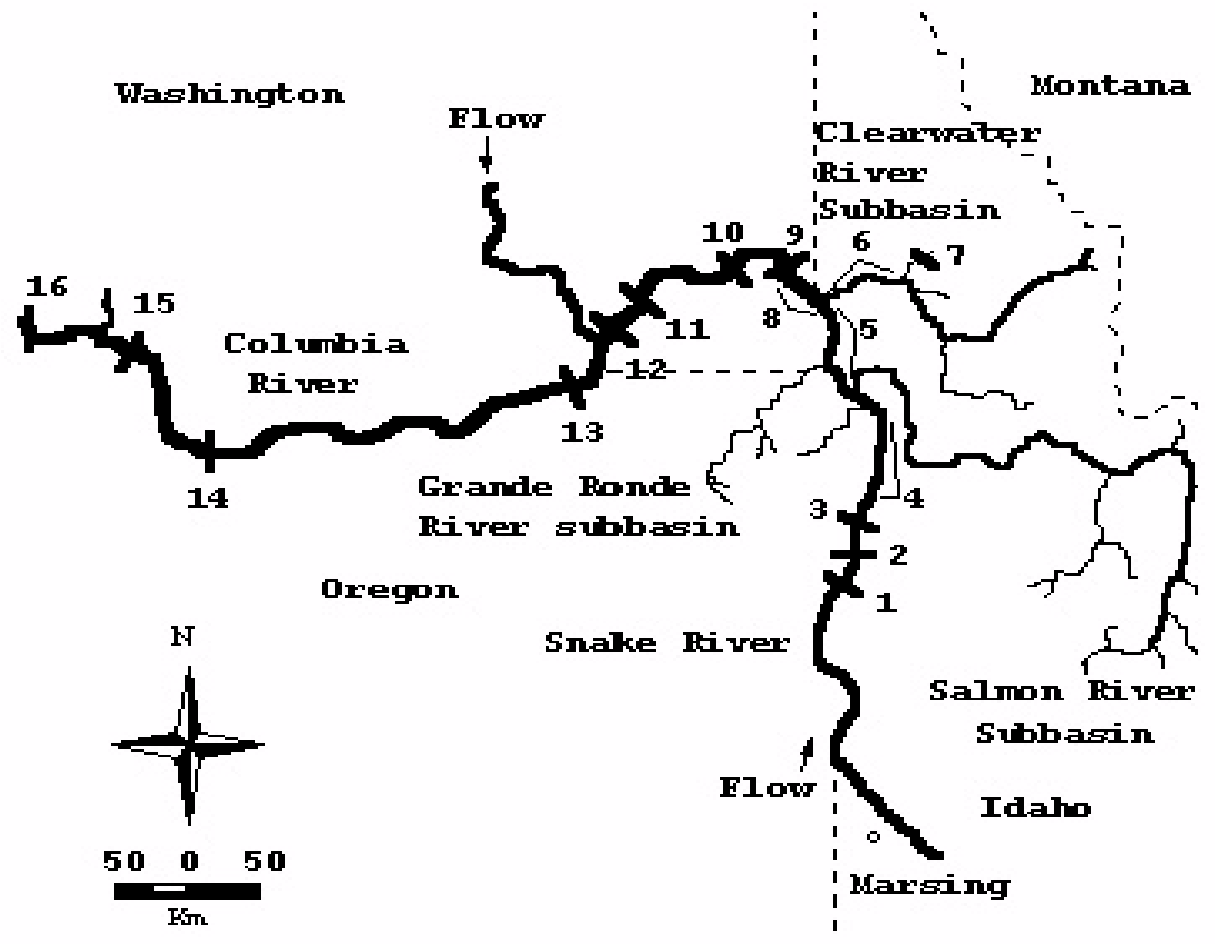

Figure 1.-Locations of the upper and lower reaches of the Snake River, the lower Clearwater River, beach seining areas, and dams that affect the early life history of snake River fall chinook salmon. Dams equipped with PIT-tag monitoring devices are indicated with an asterisk. (1) Brownlee Dam, (2) Oxbow Dam, (3) Hells Canyon Dam, (4) Upper Reach Snake River, (5) Lower Reach Snake River, (6) Lower Clearwater River, (7) Dworshak Dam, (8) Lower Granite Dam, (9) Lower Granite Dam*, (10) Little Goose Dam*, (11) Lower Monumental Dam*, (12) Ice Harbor Dam, (13) McNary Dam*, (14) John Day Dam*, (15) The Dalles Dam, (16) Bonneville Dam*. 
In the present paper, we describe emergence, rearing, early seaward migration, and growth of juvenile fall chinook salmon produced in the snake and lower Clearwater rivers as affected by the construction and operation of dams. Where possible, we make comparisons between the present-day snake River fall chinook salmon population, the population of Snake River fall chinook salmon that spawned near Marsing, Idaho prior to 1964, and other inland fall chinook salmon stocks in that inhabit the columbia River basin.

\section{Water Temperature in the Study Area}

The Snake River can be divided into two reaches (Figure 1) based on differences in water temperature. The upper reach extends from Hells Canyon Dam at river km (rkm) 399 to the confluence with the Salmon River at rkm 303. The lower reach extends from rkm 303 to the head of Lower Granite Reservoir at rkm 224. Flow through the upper reach of the snake River is almost entirely regulated by Hells Canyon Complex since there is very little tributary inflow. The upper reach is usually warmer than the lower reach throughout most of the year (Table 1; Figure 2) because the Salmon River is relatively cool and provides enough flow to the lower reach to reduce its water temperature.

The effect of Hells Canyon Complex on the water temperature regimes of the upper and lower reaches of the Snake River cannot be conclusively determined because water temperature data were not collected downstream of Hells Canyon Complex until after its completion. After dam construction, the snake River probably became warmer during late fall because the Hells Canyon Complex reservoirs retained heat absorbed as solar radiation during summer, and then released this warmer water well into the fall. Hells Canyon Complex reservoirs probably do not warm immediately in response to increases in solar radiation after the winter solstice, so relatively colder water may be released in midwinter, spring, and early summer thereby cooling the upper and lower reaches of the snake River.

Dworshak Dam was completed on the North Fork Clearwater River (Figure 1) in 1971. After Dworshak Reservoir was filled in 1973, releases of hypolimnetic and metalimnetic water warmed the lower Clearwater River in the fall, winter, and spring, and cooled the river during summer (Figure 2). Starting in 1992, Dworshak Reservoir water was released during July and August to increase survival of fall chinook salmon smolts passing 
Table 1.-Grand mean water temperatures during by season and the annual cumulative daily temperature units (CTUs) for the upper and lower reaches of the snake River, the lower Clearwater River (brood years 1991-1998), and the historic production area near Marsing, Idaho (brood years 1960-1963). Daily average water temperatures for the historic production area were provided for the snake River upstream of Marsing by the Idaho Power Company. Data for the Snake River were collected hourly using thermographs installed within each reach by the Idaho Power Company and U. S. Fish and Wildlife Service. The U.S. Geological Survey provided daily minimum and maximum water temperatures measured in the lower Clearwater River at Spalding, Idaho, which were averaged to provide daily means.

\begin{tabular}{lrccc}
\hline & $\begin{array}{c}\text { Upper reach } \\
\text { Snake River } \\
(1991-1998)\end{array}$ & $\begin{array}{c}\text { Lower reach } \\
\text { Snake River } \\
(1991-1998)\end{array}$ & $\begin{array}{c}\text { Lower Clearwater } \\
\text { River } \\
(1991-1998)\end{array}$ & $\begin{array}{c}\text { Snake River } \\
\text { Marsing } \\
(1960-1963)\end{array}$ \\
\hline Season & 12.8 & 11.2 & 8.1 & 10.6 \\
Fall & 4.4 & 4.2 & 3.8 & 5.0 \\
Winter & 12.2 & 11.4 & 9.2 & 14.0 \\
Spring & 20.5 & 20.1 & 15.9 & 20.7 \\
Summer & 4,589 & 4,314 & 3,409 & 4,629 \\
CTUs & & & & \\
\hline
\end{tabular}




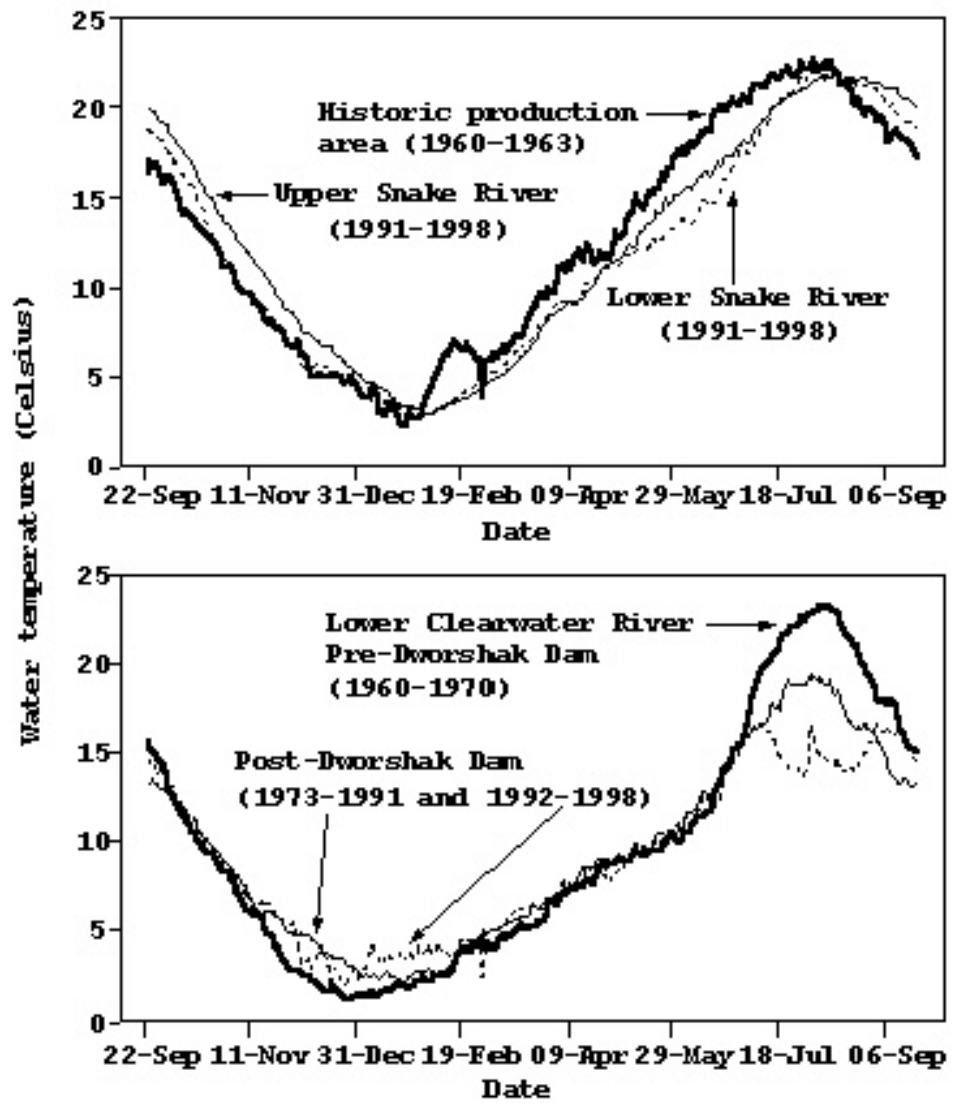

Figure 2.- Daily mean water temperatures for the upper and lower reaches of the Snake River (brood years 1991-1998), the historic production area (brood years 1960-1963) (Top), and the lower Clearwater River (before Dworshak Dam, brood years 19601970; after Dworshak Dam, brood years 1973-1991; and after summer flow augmentation, brood years 1992-1998) (Bottom). Data sources are given in the caption of Table 1. 
downstream in Lower Granite Reservoir (NMFS 1995). Multi-level selector gates were used to release water as cool as $6^{\circ} \mathrm{C}$ from the lower metalimnion of Dworshak Reservoir during July and August, which decreased summer water temperatures in the lower Clearwater River below 1973-1991 levels (Figure 2).

Water temperatures in the historic production area near Marsing, Idaho during the four years (brood years 1960-1963) prior to fall chinook salmon extirpation, differed from the water temperatures experienced by present-day fall chinook salmon in the Snake and Clearwater Rivers (Table 1). Fall water temperatures in the historic production area were cooler than in the upper and lower reaches of the snake River, and warmer than in the lower Clearwater River (Table 1). Water temperatures of the historic production area were warmer than all three presentday production areas in the winter, spring, and summer (Table 1). On an annual basis (based on cumulative daily temperature units) the historic production area was the warmest followed by the upper reach of the snake River, the lower reach of the Snake River, and the lower Clearwater River (Table 1).

\section{Methods}

Data collection

We collected wild subyearling chinook salmon by beach seining (Connor et al. 1998) permanent and non-permanent stations. Stations were located along the upper reach of the Snake River from rkm 361 to rkm 314 (1995-2000), the lower reach of the Snake River from rkm 291 to rkm 224 (1992-2000), and the lower Clearwater River from rkm 64 to rkm 16 (1993-1995) (Figure 1). Beach seining at permanent stations typically began in April soon after fry began emerging from the gravel, and was conducted one day per week within each production area. Weekly sampling continued into June or July until few or no fish were collected. Supplemental sampling was typically conducted one day per week in each production area for three consecutive weeks once a majority of fish were $\geq 60-\mathrm{mm}$ fork length. We inserted passive integrated transponders (PIT tags) (Prentice et al. 1990b) into fish $\geq 60-\mathrm{mm}$ fork length (Connor et al. 1998). Tagged fish were released where they were collected to resume rearing.

After beginning seaward migration, some of the PIT-tagged subyearling chinook salmon were detected passing through the 
juvenile bypass systems of dams equipped with PIT-tag monitors (Matthews et al. 1977; Prentice et al. 1990a; Connor et al. 2000) (Figure 1). Operation schedules for the fish bypass systems varied by dam and year. Most of the detections occurred in the fish bypass systems of Lower Granite, Little Goose, and Lower Monumental dams (Figure 1) operated from early April to early November, and at McNary Dam (Figure 1) operated from early April to early December.

We recaptured subsamples of PIT-tagged wild subyearling chinook salmon passing Lower Granite or Little Goose dams from 1992 to 1998 to determine the genetic lineage (i.e., fall or spring/summer chinook salmon) of individual fish (Marshall et al. 2000; Connor et al. In reviewa). In 1999 and 2000, we systematically collected fish from the beach seine catch to nonlethally assess the genetic lineage of individual fish (Connor et al. In reviewa).

Early life history

We focused our analyses of early life history on 1995 data because beach seine catch was composed primarily of wild subyearling fall chinook salmon, environmental conditions were average, and all three of the present-day production areas were sampled. We presented data from other years to corroborate the 1995 findings. The presence of subyearling spring/summer chinook salmon should be considered when viewing our results because the genetic lineage of every fish we sampled could not be determined. Wild subyearling spring/summer chinook salmon in our catch makes rearing and early seaward migration timing we report for fall chinook salmon seem slightly earlier than is the case (Connor et al. In reviewa).

We used the capture dates for wild subyearling chinook salmon < 45-mm fork length to describe time of presence for newly emergent fall chinook salmon fry. We used the capture dates for fish > 45-mm fork length to describe time of presence for fall chinook salmon parr. All capture dates were adjusted to Sunday's date the week of sampling to account for differences in day of sampling among the three production areas. We used a Kolmogorov-Smirnov three-sample test (Kiefer 1959) to test for significant differences (alpha $=0.05$ ) in the date distributions of fry and parr presence among the three production areas. We used Kolmogorov-Smirnov two sample tests (Daniel 1978) to make pair-wise comparisons (alpha $=0.05$ ) between date distributions 
of two production areas when there was a significant difference in a three-sample test.

We used the detection data at Lower Granite Dam, which is the first dam encountered en route to the Pacific Ocean, to represent the onset of seaward migration by subyearling fall chinook salmon smolts. We compared the detection date distributions of smolts among the three production areas using Kolmogorov-Smirnov three-sample and two-sample tests as previously described for fry and parr analyses.

We used the detection data collected at all dams equipped with PIT-tag monitoring equipment (Figure 1) to determine the proportion of smolts from each of the three productions that were last detected in freshwater as yearlings. We used contingency table analysis (Zar 1984) to compare (alpha $=0.05$ ) the proportion of the PIT-tagged smolts from each production area that was last detected as yearlings. Tukey-type pair-wise comparisons were made between production areas to test for significant differences (alpha $=0.05$ ) in the arcsine transformed proportions (Zar 1984).

Growth

We calculated four measures of growth. We used the length and weight data for fry and parr collected at initial capture to fit the equation $w=a l^{b}$ (Ricker 1975). We calculated condition factor $(K)$ for parr and smolts using the equation $K=\mathrm{W} / \mathrm{L}^{3} \times 10^{5}$. We calculated absolute growth rate $(\mathrm{mm} / \mathrm{d})$ during rearing using length data from PIT-tagged parr recaptured by beach seine after initial capture and tagging. We calculated absolute growth rate as: fork length at recapture minus fork length at initial capture divided by the number of days between initial capture and recapture. We calculated absolute growth rate during early seaward migration using the same equation except smolt fork length at recapture was measured on fish recaptured after passing Lower Granite Dam.

We compared (alpha $=0.05$ ) the slopes of the geometric mean (GM) regression equations describing the relation between weight and length as described by Zar (1984). We used analysis of variance (ANOVA) and the 1995 data to test for differences (alpha $=0.05$ ) in condition factors and absolute growth rates of parr and smolts among the three production areas. Tukey type pair-wise comparisons (Zar 1984) were made between growth of 
parr or smolts of two production areas to test for significant differences (alpha $=0.05)$.

\section{Results}

Sample Sizes and Genetics

We captured 5,869 wild subyearling chinook salmon in the upper reach of the Snake River from 1995 to 2000, 19,875 in the lower reach of the Snake River from 1992 to 2000, and 2,356 in the lower Clearwater from 1993 to 1995 (Table 2). We inserted PIT tags into 2,633, 9,517, and 1,520 fish in the upper reach of the Snake River, lower reach of the Snake River, and lower Clearwater River (Table 2). The percentage of fall chinook salmon in samples collected for genetic analysis ranged from 59.5 to $100.0 \%$ for the upper reach of the snake River, 42.2 to 93.3\% for the lower reach of the snake River, and from 33.3 to $100.0 \%$ for the lower Clearwater River (Table 2). The remaining fish in the samples collected for genetic analysis were identified as wild subyearling spring/summer chinook salmon.

\section{Early Life History}

Fry emergence in 1995 occurred earliest in the upper reach of the Snake River (median = 23-Apr; range 2-April to 21-May), followed by the lower reach of the Snake River (median = 30-Apr; range 2-April to 4-June), and the lower Clearwater River (median 18 June; range 2 April to 2 July) based on time of fry presence (Table 3; Figure 3). The date distributions of fry presence in 1995 differed significantly (KSa $=8.099 ; P<0.0001)$, and each pair-wise comparison was significant (upper versus lower reach of the Snake River $\mathrm{KSa}=3.190, P \leq 0.0001$; upper reach of the Snake River versus lower Clearwate $\bar{r} \mathrm{KSa}=6.992, P \leq 0.0001$; lower reach of the snake River versus lower clearwater $\mathrm{KSa}=$ 7.702, $P<0.0001$ ) (Figure 3). The grand median dates of presence for fry corroborate a consistent difference in fry emergence timing over years among the three production areas (upper reach of the Snake River $=22$-April; lower reach of the Snake River = 2-May; lower Clearwater River = 19-June) (Table 3).

Shoreline rearing by parr in 1995 occurred earliest in the upper reach of the Snake River (median 28-May; range 9-April to 21-June), followed by the lower reach of the snake River (median 4-June; range 2-April to 2-July), and the lower Clearwater River 
Table 2.-Number of wild subyearling chinook salmon collected along the upper and lower reaches of the snake River and the lower Clearwater River by year including the number of fish PIT tagged and results of analyses to determine genetic lineage (i.e., fall or spring/summer run) of individual fish.

Genetic results

\begin{tabular}{|c|c|c|c|c|c|c|}
\hline Year & $\begin{array}{l}\text { Number } \\
\text { collected }\end{array}$ & $\begin{array}{l}\text { Number } \\
\text { tagged }\end{array}$ & $N$ & $\begin{array}{l}\text { Percent } \\
\text { fall-rur }\end{array}$ & Citation & \\
\hline & & Upper & = Reach & h Snake & River & \\
\hline 1995 & 1,101 & 568 & 65 & 100.0 & Marshall et al. & $(2000)$ \\
\hline 1996 & 132 & 51 & 9 & 100.0 & Unpublished data & \\
\hline 1997 & 120 & 87 & 17 & 100.0 & " & , \\
\hline 1998 & 1,179 & 628 & 79 & 59.5 & $"$ & , \\
\hline 1999 & 1,590 & 918 & 62 & 98.4 & $"$ & , \\
\hline 2000 & 1,747 & 381 & $\mathrm{TBD}$ & TBD & $"$ & ' \\
\hline
\end{tabular}

Lower Reach Snake River

$\begin{array}{rrrrrl}1992 & 2,191 & 1,056 & 16 & 87.5 & \text { Unpublished data } \\ 1993 & 2,415 & 1,252 & 116 & 42.2 \text { Connor et al. (In reviewa) } \\ 1994 & 4,787 & 2,337 & 115 & 80.0 \text { " } \\ 1995 & 1,662 & 801 & 45 & 93.3 & \text { Marshall et al. (2000) } \\ 1996 & 1,024 & 413 & 26 & 84.6 & \text { Connor et al. (In reviewa) } \\ 1997 & 1,051 & 553 & 25 & 56.0 \text { " } \\ 1998 & 2,828 & 1,432 & 70 & 54.3 & \text { " } \\ 1999 & 1,924 & 843 & 161 & 83.9 & \text { Unpublished data } \\ 2000 & 1,993 & 830 & --- & --- & \end{array}$

\section{Lower Clearwater River}

$\begin{array}{lccccl}1993 & 552 & 367 & 3 & 33.3 & \text { Unpublished data } \\ 1994 & 1,019 & 695 & - & ---- & \mathrm{N} / \mathrm{A} \\ 1995 & 785 & 458 & 3 & 100.0 & \text { Unpublished data }\end{array}$


Table 3.-Dates of presence (given as Sunday's date for each week) of wild subyearling chinook salmon fry and parr that were collected in the upper and lower reaches of the snake River and the lower Clearwater River, and the passage dates at Lower Granite Dam for PIT-tagged smolts, 1992-2000.

\begin{tabular}{ccccc} 
& \multicolumn{2}{c}{ Dates of presence } & & Lower Granite Dam \\
\cline { 2 - 3 } & Fry & Parr & & Minimum \\
& Minimum & Minimum & & Median \\
Median & Median & & Maximum \\
Mear & Maximum & Maximum & & $(N)$ \\
\hline
\end{tabular}

Upper Reach Snake River

\begin{tabular}{|c|c|c|c|}
\hline \multirow[t]{4}{*}{1995} & 02-Apr & 09-Apr & 04-Jun \\
\hline & 23-Apr & 28-May & $18-J u l$ \\
\hline & 21-May & $21-J u n$ & $24-$ oct \\
\hline & (117) & (984) & (203) \\
\hline \multirow[t]{4}{*}{1996} & 14-Apr & 14-Apr & 20-May \\
\hline & 28-Apr & 12-May & $04-\mathrm{Jul}$ \\
\hline & 05-May & 16-Jun & $25-\mathrm{Jul}$ \\
\hline & (14) & (118) & (19) \\
\hline \multirow[t]{4}{*}{1997} & 20-Apr & 20-Apr & 04-Jun \\
\hline & 20-Apr & 25-May & $27-\mathrm{Jul}$ \\
\hline & 20-Apr & 15-June & 13-Aug \\
\hline & (1) & (119) & $(22)$ \\
\hline \multirow[t]{4}{*}{1998} & 12-Apr & 12-Apr & 19-May \\
\hline & 19-Apr & 17-May & $07-J u l$ \\
\hline & 10-May & 05-Jul & 21-Aug \\
\hline & $(101)$ & $(1,078)$ & (173) \\
\hline \multirow[t]{4}{*}{1999} & $04-A p r$ & 11-Apr & 02-Jun \\
\hline & 02-May & 23-May & 03-Jul \\
\hline & 23-May & 27-Jun & 28-Aug \\
\hline & (97) & $(1,493)$ & (319) \\
\hline \multirow[t]{4}{*}{2000} & 02-Apr & 02-Apr & $06-\mathrm{May}$ \\
\hline & 09-Apr & 23-Apr & 28-Jun \\
\hline & 14-May & 11-Jun & 18-Aug \\
\hline & (683) & $(1,064)$ & (70) \\
\hline
\end{tabular}


Table 3.-(Continued)

Grand

22-Apr

20-May

04-Jul

medians

Lower Reach Snake River

1992

29-Mar

29-Mar

$04-$ May

26-Apr

17-May

20-Jun

24-May

07-Jun

21-Jul

(359)

$(1,832)$

1993

$04-A p r$

11-Apr

31-May

16-May

06-Jun

21-Jul

20-Jun

18-Jul

25-Oct

(199)

$(2,216)$

(234)

1994

03-Apr

03-Apr

23-May

15-May

29-May

17-Jul

05-Jun

10-Jul

(440)

$(4,347)$

01-Nov

(193)

1995

02-Apr

02-Apr

01-Jun

30-Apr

04-Jun

02-Aug

04-Jun

02-Jul

26-Oct

(257)

$(1,405)$

(235)

1996

14-Apr

05-May

14-Apr

17-May

26-May

21-Jul

23-Jun

14-Jul

31-Oct

(268)

(756)

(127)

1997

20-Apr

20-Apr

14-Jun

0 4-May

08-Jun

16-Jul

29-Jun

13-Jul

13-Oct

(114)

(937)

(97)

1998

12-Apr

26-Apr

14-Jun

12-Apr

29-May

31-Mar

12-Jul

05-July

13-Oct

(322)

$(2,506)$

(375)

1999

04-Apr

04-Apr

01-Jun

02-May

06-Jun

25-Jul

27-Jun

11-Jul

30-Aug

(278)

$(1,646)$

(240) 


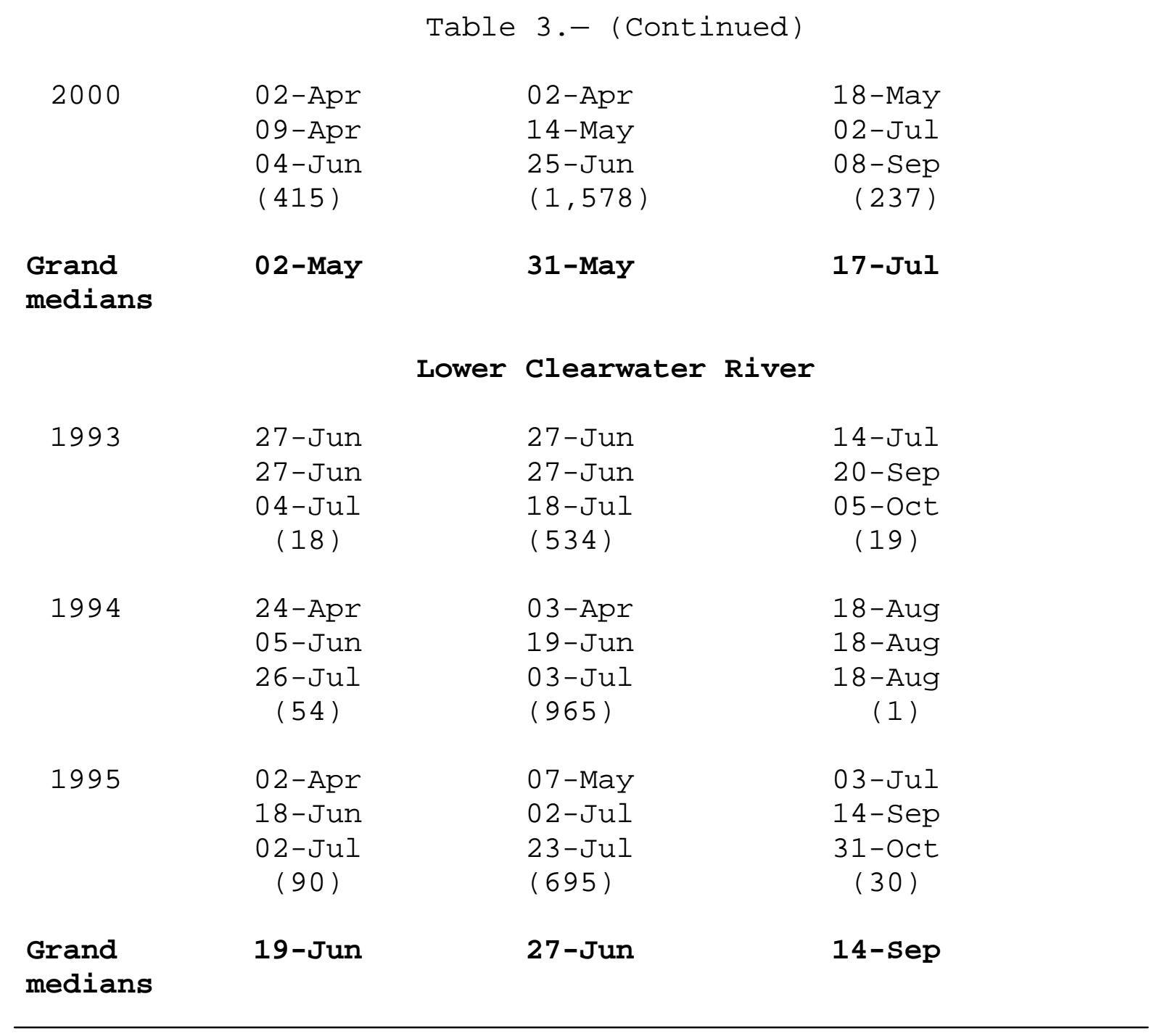




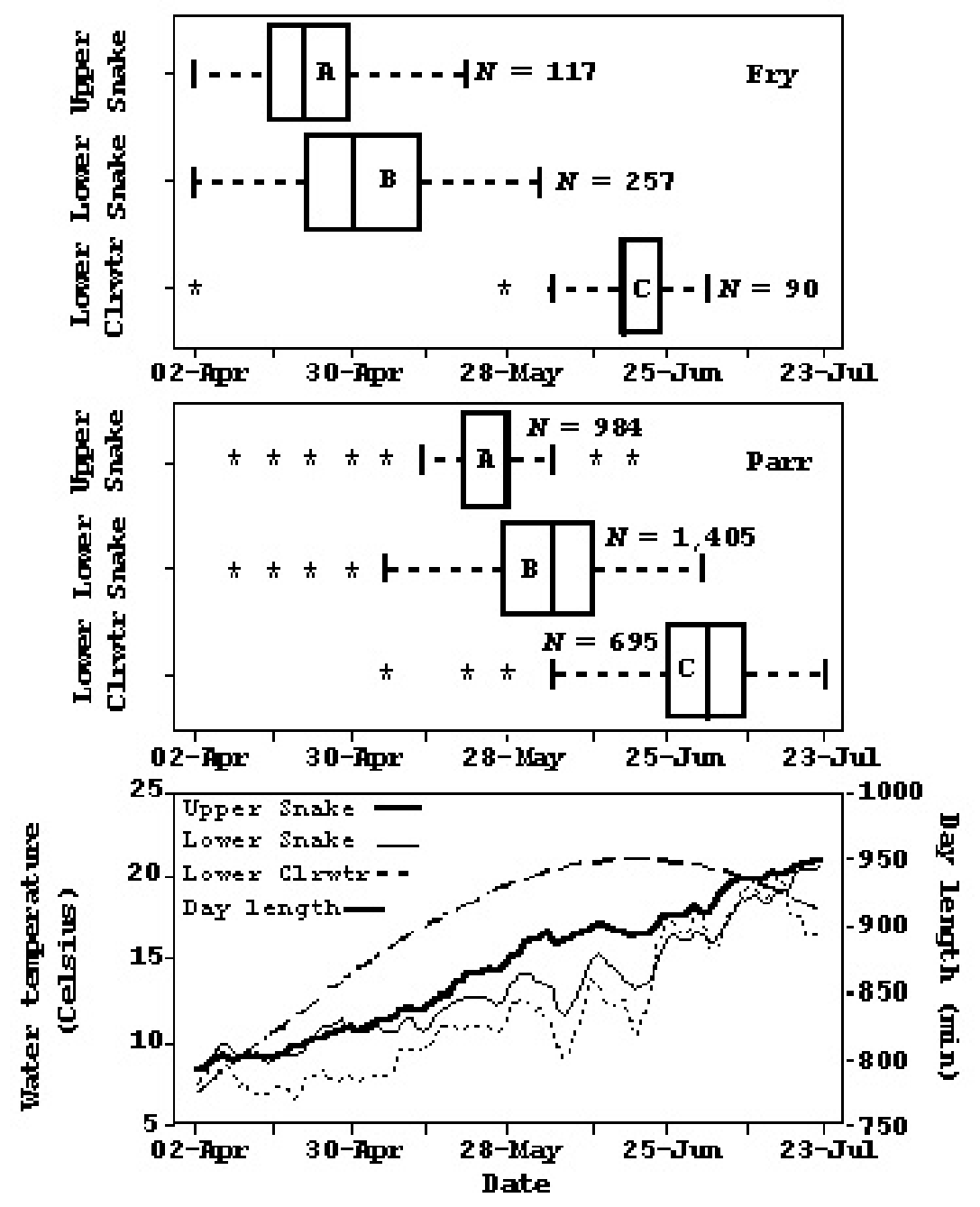

Figure 3.- Sideways box plots (Ott 1993) showing the timing of fry presence (Top), timing of parr presence (Middle), mean daily water temperature and day length (Bottom) in 1995 for the upper and lower reaches of the Snake River (abbreviated upper Snake and lower snake) and the lower Clearwater River (abbreviated lower Clrwtr). Water temperature data sources are given in the caption of Table 1. Day length was measured by the U. S. Navy at the confluence of the snake and clearwater rivers. A unique letter in a box indicates that the date distribution differed significantly (alpha $=0.05$ ) from the other two given for the life stage. 
(median 2-July; range 7-May to 23-July) based on time of parr presence (Table 3; Figure 3). The date distributions of parr presence in 1995 differed significantly (KSa $=19.064 ; P \leq$ 0.0001 ) (Figure 3), and each pair-wise comparison was significant (upper versus lower reach of the snake River $\mathrm{KSa}=8.381$, $P \leq$ 0.0001 ; upper reach of the Snake River versys lower Clearwater $\mathrm{KSa}=17.859, P \leq 0.0001$; lower reach of the Snake River versus lower Clearwater $\mathrm{KSa}=16.384, P \leq 0.0001$ ) (Figure 3). The grand median dates of presence for parr corroborate a consistent difference over years in time of shoreline rearing among the three production areas (upper reach of the snake River = 20-May; lower reach of the snake River = 31-May; and lower Clearwater River $=27$-June) $($ Table 3$)$.

Water temperature when the majority (all but the outliers shown as asterisks in Figure 3) of parr were rearing along the shoreline in 1995 averaged $14.3^{\circ} \mathrm{C}$ in the upper reach of the snake River, $13.3^{\circ} \mathrm{C}$ in the lower reach of the snake River, and $15.1{ }^{\circ} \mathrm{C}$ in the lower Clearwater River (Figure 3). Day length in 1995 was increasing throughout the time fall chinook salmon parr were present along the shoreline of the upper reach of the snake River (Figure 3). Day length in 1995 began to decrease while many parr were still rearing along the shoreline of the lower reach of the Snake River (Figure 3). Most parr were still rearing along the shoreline of the lower Clearwater River in 1995 well after 21-June when day length began to decrease (Figure 3). The maximum water temperature when parr were present along the shoreline in 1995 was $20.5^{\circ} \mathrm{C}$ (Figure 3). During all years studied, shoreline rearing was complete or near completion before water temperature exceeded $21.0^{\circ} \mathrm{C}$.

Smolts from the upper reach of the Snake River began seaward migration earliest (median $=18-J u l y$; range 4-June to 24-October), followed by smolts from the lower reach of the Snake River (median = 2-August; range 1-June to 26-October), and smolts from the lower Clearwater River (median = 14-September; range 3-July to 31-October) based on detection dates of PITtagged smolts at Lower Granite Dam in 1995 (Table 3; Figure 4). The detection date distributions in 1995 differed significantly $(\mathrm{KSa}=4.190 ; P \leq 0.0001)$ (Figure 4), and all pair-wise comparisons were significant (upper versus lower reach of the Snake River $\mathrm{KSa}=3.605, P \leq 0.0001$; upper reach of the Snake River versus lower Clearwater $\mathrm{KSa}=3.542, P \leq 0.0001$; lower reach of the Snake River versus lower Clearwater $\mathrm{KSa}=2.286 ; P$ $\leq 0.0001$ ) (Figure 4). The grand median detection dates for subyearling smolts at Lower Granite Dam corroborate a consistent difference over years in time of early seaward migration among 

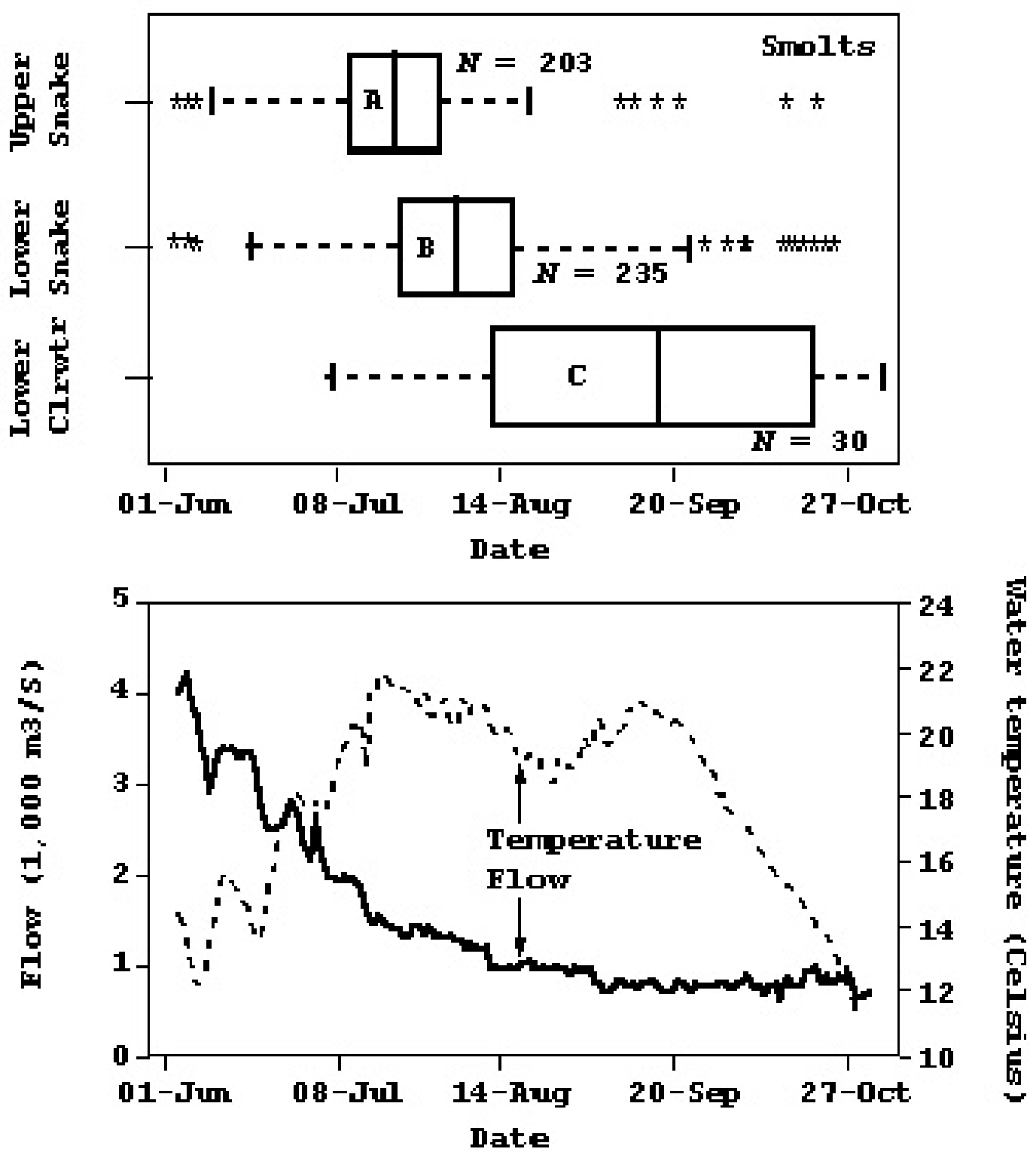

Figure 4.-Sideways box plots (Ott 1993) showing passage timing at Lower Granite Dam for PIT-tagged smolts from the upper and lower reaches of the Snake River (abbreviated upper snake and lower Snake) and the lower Clearwater River (abbreviated lower Clrwtr)(Top), and the mean daily water flow and temperature (Bottom) measured in Lower Granite Reservoir by the U. S. Army Corps of Engineers in 1995. A unique letter in a box indicates that the date distribution differed significantly (alpha $=0.05$ ) from the other two. 
smolts of the three production areas (upper reach of the snake River $=4-J u l y ;$ lower reach of the Snake River $=17-J u l y$; and lower Clearwater River = 14-September) (Table 3).

Subyearling smolts from all three production areas passed Lower Granite Dam in 1995 after reservoir flow peaked and was declining to base summer levels, and when water temperature was increasing to the summer maximum (Figure 4). Mean flow in Lower Granite Reservoir during the time the majority (all but the outliers shown as asterisks in Figure 4) of smolts passed Lower Granite Dam was 2,174, 1,435, and 1,068 $\mathrm{m}^{3} / \mathrm{s}$ for smolts from the upper reach of the snake River, lower reach of the Snake River, and lower Clearwater River. Water temperature in Lower Granite Reservoir during the time smolts from all three production areas passed Lower Granite Dam reached a maximum of $21.8^{\circ} \mathrm{C}$.

The proportion of PIT-tagged smolts from 1995 releases that was last detected as yearlings in 1996 at dams in the snake and Columbia rivers was 0.009 for the upper reach of the snake River, 0.039 for the lower reach of the snake River, and 0.063 for the lower Clearwater River (Table 4; Figure 5). These proportions differed significantly $\left(X^{2}=8.149 ; P<0.05\right)$. The proportion of tagged smolts last detected as yearlings was significantly lower for the upper reach of the snake River (upper reach versus lower reach of the snake River $q=7.36, P<$ 0.05; upper reach of the Snake River versus lower Clearwater River $q=6.15, P \leq 0.05)$ (Figure 5). The proportion of smolts from the lower reach of the Snake River and the lower clearwater River last detected as yearlings varied considerably among release years, but the grand means are consistent with the 1995 findings (upper reach of the snake River $=0.015+0.012$; lower reach of the Snake River $=0.112+0.082$; lower Clearwater River $=$ $0.521+0.336)($ Table 4).

Growth

The geometric mean (GM) regression equation for the upper reach of the Snake River was $\log _{10}$ Weight $=-5.834+3.479 \mathrm{x}$ $\log _{10}$ Length $\left(r^{2}=0.985 ; P \leq 0.0001\right)($ Table 5$)$. Therefore, $w=$ $0.0000015 \times 1^{3.479}$ (Table 5). For the lower reach of the Snake River, the GM regression equation was Log $_{10}$ Weight $=-5.819+$ $3.479 \times \log _{10}$ Length $\left(r^{2}=0.968 ; P \leq 0.0001\right)$ (Table 5) and $w=$ $0.0000015 \times 1^{3.481}$. The GM regression equation for the lower Clearwater River was Log $_{10}$ Weight $=-6.371+3.784 \times$ Log $_{10}$ Length $\left(r^{2}=0.928 ; P \leq 0.0001\right)$ (Table 5) and $w=0.0000004 \times 1^{3.784}$. The slope coefficients of the GM regression equations differed 
Table 4.-The number of final detections $(N)$ of PIT-tagged wild subyearling chinook salmon smolts at snake and Columbia river dams, and the proportions by age at detection by production area and release year, 1992-1998.

\section{Proportion}

\begin{tabular}{|c|c|c|c|c|}
\hline Production area & Year & $N$ & Subyearlings & Yearlings \\
\hline Upper Reach & 1995 & 328 & 0.991 & 0.009 \\
\hline \multirow[t]{3}{*}{ Snake River } & 1996 & 30 & 0.967 & 0.033 \\
\hline & 1997 & 47 & 1.000 & 0.000 \\
\hline & 1998 & 324 & 0.981 & 0.019 \\
\hline Grand means & & & $0.985 \pm 0.012$ & $0.015 \pm 0.012$ \\
\hline Lower Reach & 1992 & 68 & 0.956 & 0.044 \\
\hline \multirow{6}{*}{ Snake River } & 1993 & 356 & 0.834 & 0.166 \\
\hline & 1994 & 338 & 0.746 & 0.254 \\
\hline & 1995 & 361 & 0.961 & 0.039 \\
\hline & 1996 & 171 & 0.942 & 0.058 \\
\hline & 1997 & 173 & 0.815 & 0.185 \\
\hline & 1998 & 687 & 0.961 & 0.039 \\
\hline Grand means & & & $0.888+0.08 .2$ & $0.112+0.082$ \\
\hline Lower Clearwater & 1993 & 73 & 0.356 & 0.644 \\
\hline \multirow[t]{2}{*}{ River } & 1994 & 28 & 0.143 & 0.857 \\
\hline & 1995 & 48 & 0.938 & 0.063 \\
\hline Grand means & & & $0.479+0.336$ & $52.1+0.336$ \\
\hline
\end{tabular}




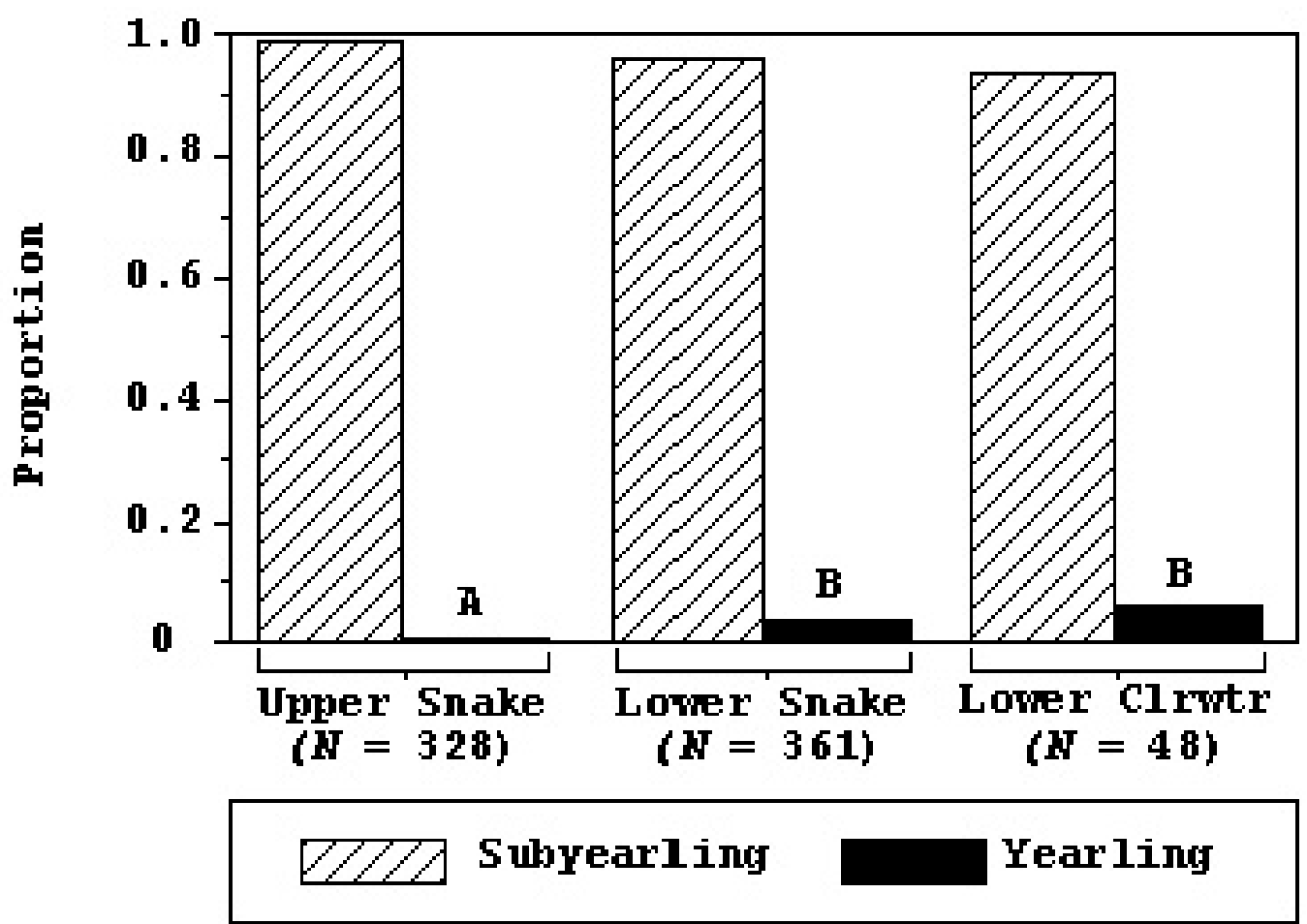

Figure 5.-The proportions of PIT-tagged wild subyearling chinook salmon from the upper and lower reaches of the snake River (abbreviated upper snake and lower snake) and the lower Clearwater River (abbreviated lower Clrwtr) that were last detected as subyearling and yearling smolts at dams in the snake and Columbia rivers. A unique letter over the yearling bar indicates that the proportion of yearling detections differed significantly (alpha $=0.05)$ from the other two. 
Table 5.-Number of fish measured $(N)$, geometric mean (GM) equations ( $B_{\circ}=$ constant and $B_{1}=$ slope coefficient) for describing growth in weight with fork length (FL) for wild subyearling chinook salmon collected in the upper and lower reaches of the snake River and the lower Clearwater River, 19922000 .

\begin{tabular}{|c|c|c|c|c|c|c|c|}
\hline & & Mean & Mean & GM & equation & & \\
\hline Year & $N$ & $(\overline{\mathrm{mm}})$ & $(g)$ & $\mathrm{B}_{\circ}$ & $B_{1}$ & $r^{2}$ & $P$ \\
\hline
\end{tabular}

Upper Reach Snake River

$\begin{array}{rrrrrrrr}1995 & 722 & 65.0+16.995 & 3.8+3.245 & -5.834 & 3.479 & 0.985 & <0.0001 \\ 1996 & 122 & 64.5+13.119 & 3.5+2.493 & -5.655 & 3.392 & 0.987 & <0.0001 \\ 1997 & 115 & 77.4+10.975 & 6.0+2.722 & -5.832 & 3.483 & 0.981 & <0.0001 \\ 1998 & 1,068 & 64.2+14.892 & 4.3+3.102 & -5.616 & 3.380 & 0.983 & <0.0001 \\ 1999 & 1,580 & 67.4+14.340 & 4.1+3.045 & -5.706 & 3.414 & 0.984 & <0.0001 \\ 2000 & 1,452 & 58.1+19.656 & 2.9+3.575 & -5.725 & 3.409 & 0.985 & <0.0001\end{array}$

\section{Lower Reach Snake River}

$\begin{array}{rrrrrrrr}1992 & 1,205 & 69.0+12.274 & 4.1+2.486 & -5.329 & 3.206 & 0.958 & <0.0001 \\ 1993 & 2,042 & 65.8+15.555 & 3.1+3.089 & -5.237 & 3.163 & 0.952 & <0.0001 \\ 1994 & 4,124 & 64.3+15.670 & 3.5+2.840 & -5.612 & 3.353 & 0.962 & <0.0001 \\ 1995 & 1,116 & 61.1+16.848 & 3.3+3.228 & -5.819 & 3.479 & 0.968 & <0.0001 \\ 1996 & 942 & 60.9+11.365 & 3.4+2.928 & -5.573 & 3.349 & 0.978 & <0.0001 \\ 1997 & 1,029 & 66.4+16.144 & 4.3+3.169 & -5.500 & 3.317 & 0.980 & <0.0001 \\ 1998 & 2,404 & 63.6+14.880 & 3.7+2.789 & -5.414 & 3.270 & 0.977 & <0.0001 \\ 1999 & 1,916 & 62.2 \pm 15.682 & 3.3+2.827 & -5.684 & 3.398 & 0.982 & <0.0001 \\ 2000 & 1,924 & 61.4 \pm 16.383 & 3.0+2.963 & -5.672 & 3.388 & 0.981 & <0.0001\end{array}$

Lower Clearwater River

$\begin{array}{llllllll}1993 & 371 & 68.0+12.821 & 3.9+2.290 & -5.222 & 3.146 & 0.958 & <0.0001 \\ 1994 & 993 & 66.7 \pm 11.488 & 3.8+1.949 & -4.505 & 3.479 & 0.966 & <0.0001 \\ 1995 & 165 & 61.7 \pm 11.401 & 2.9 \pm 1.739 & -6.370 & 3.784 & 0.928 & <0.0001\end{array}$


significantly among the three production areas $(F=4.30 ; P<$ 0.05). The slope coefficient of the lower Clearwater River GM regression equation was significantly larger $(q=7.569 ; P<$ $0.05)$ than the slope coefficients of either snake River equation. However, the grand mean slope coefficients were similar (upper reach snake River $=3.426+0.040$; lower reach Snake River $=3.325+0.093$; lower Clearwater River $=3.470+0.262$ ) and did not support a consistent difference over years for the relation between weight and fork length.

Condition factors, $K$, for parr during rearing in 1995 were similar among production areas (upper reach of the snake River $N$ $=605$, mean $=1.1+0.142$; lower reach of the snake River $N=887$, mean $=1.1+0.156 ;$ lower Clearwater River $N=152$, mean $=$ $1.1+0.171)$ (Table 6), and there was no significant difference among the means (one-way ANOVA, DF $=2 ; \mathrm{MSE}=0.0233 ; F=0.96$; $P=0.382)$. The grand mean condition factor for parr was $1.2+0.050$ for the upper reach of the Snake River, $1.1+0.050$ for the lower reach of the Snake River, and $1.1+0.047$ for the lower Clearwater River (Table 6), which corroborates a consistent similarity in condition factor over years among parr of the three production areas.

Absolute growth rate for parr during shoreline rearing in 1995 was fastest in the upper reach of the Snake River $(\underline{N}=145$; mean $=1.2 \mathrm{~mm} / \mathrm{d} ; \mathrm{SD}=0.253$ ) and similar between parr in the lower reach of the snake River $(N=78$; mean $=1.0 \mathrm{~mm} / \mathrm{d}$; $\mathrm{SD}=$ $0.353)$ and the lower Clearwater River $(N=18$; mean $=0.9 \mathrm{~mm} / \mathrm{d}$; $\mathrm{SD}=0.428)($ Table 6). Parr growth rates in 1995 differed significantly (one-way ANOVA, $\mathrm{DF}=2 ; \mathrm{MSE}=0.095 ; F=23.24 ; P$ $\leq 0.0001)$. Growth rate was significantly $(P<0.05)$ faster for parr in the upper reach of the snake River. There was no significant difference between growth rates of parr in the lower reach of the snake River and the lower Clearwater River. The grand mean growth rates calculated for parr (upper reach of the Snake River $=1.2+0.090 \mathrm{~mm} / \mathrm{d}$; lower reach of the Snake River = $0.9+0.113 \mathrm{~mm} / \mathrm{d}$; lower Clearwater River $=0.8+0.094 \mathrm{~mm} / \mathrm{d})(\mathrm{Table}$ 6) Corroborate a consistent difference over years in parr growth rates among the three production areas.

Condition factor $K$ for was similar among smolts from the three production areas that were recaptured during early seaward migration at Lower Granite Dam in 1995 (upper reach of the Snake River $N=131$, mean $=1.4+0.168$; lower reach of the Snake River $N=143$, mean $=1.4+0.272 \bar{i}$ lower Clearwater River $N=14$, mean = 1.4+0.116) (Table 6), and there was no significant difference among the means (one-way ANOVA, $\mathrm{DF}=2 ; \mathrm{MSE}=0.0508 ; F=1.16$; 
Table 6.-Mean condition factors $(K)$ and absolute growth rates for wild subyearling chinook salmon parr during rearing that were collected in the upper and lower reaches of the snake and lower Clearwater River in a beach seine, and for smolts that were recaptured at Lower Granite Dam or Little Goose Dam, 19922000 .

\begin{tabular}{|c|c|c|c|c|c|c|c|c|}
\hline \multirow[b]{2}{*}{ Year } & \multirow[b]{2}{*}{$N$} & \multicolumn{3}{|c|}{ Parr } & \multicolumn{4}{|c|}{ Smolt } \\
\hline & & $K+S D$ & $N$ & $\begin{array}{l}\text { Growth+SD } \\
(\mathrm{mm} / \mathrm{d})\end{array}$ & $N$ & $K+S D$ & $N$ & $\begin{array}{l}\text { Growth+SD } \\
(\mathrm{mm} / \mathrm{d})\end{array}$ \\
\hline
\end{tabular}

\section{Upper Reach Snake River}

\begin{tabular}{|c|c|c|c|c|c|c|c|c|}
\hline 1995 & 605 & $1.1+0.142$ & 145 & $1.2+0.253$ & 131 & $1.4+0.168$ & 132 & $1.3+0.170$ \\
\hline 1996 & 112 & $1.2+0.105$ & 19 & $1.1+0.245$ & 12 & $1.1+0.049$ & 9 & $1.3+0.133$ \\
\hline 997 & 114 & $1.2+0.109$ & 20 & $1.3+0.322$ & 17 & $1.1+0.096$ & 19 & $1.2+0.143$ \\
\hline 998 & 980 & $1.2 \overline{+} 0.129$ & 110 & $1.1+0.295$ & 84 & $1.1+0.091$ & 105 & $1.4 \overline{+0} .147$ \\
\hline 999 & 1,489 & $1.1+0.119$ & 168 & $1.3+0.315$ & --- & --------- & --- & ----- \\
\hline 0 & 932 & $1.1+0.115$ & 95 & $1.3+0.202$ & --- & ---------- & --- & -- \\
\hline eans & & $1.2 \pm 0.050$ & & $1.2 \pm 0.090$ & & $1.2 \pm 0.130$ & & $1.3 \pm 0.07$ \\
\hline
\end{tabular}

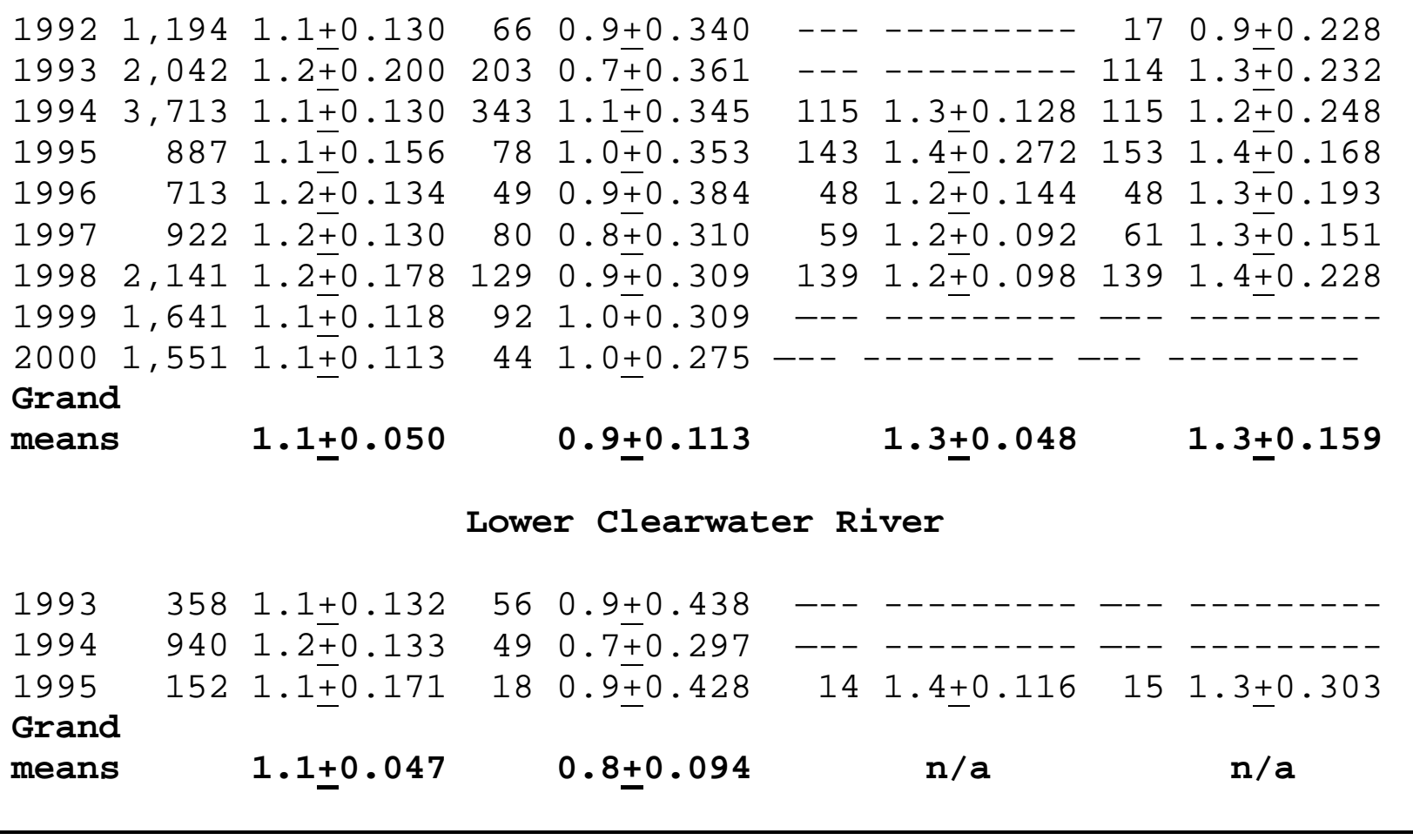


$P=0.315)$. The grand mean condition factor for smolts was $1.2+0.130$ for the upper reach of the Snake River and $1.3+0.080$ for the lower reach of the snake River (Table 6), which corroborates a consistent similarity in smolt condition factor over years between these two production areas.

Mean fork length in 1995 was $142.9 \mathrm{~mm}(\mathrm{SD}=16.609)$ for smolts from the upper reach of the Snake River, $151.3 \mathrm{~mm}$ (SD = 20.853) for smolts from the lower reach of the snake River, and $140 \mathrm{~mm}$ ( $\mathrm{SD}=34.597$ ) for smolts from the lower Clearwater River. Mean fork length of smolts for other years ranged from 111.5 to $144.6 \mathrm{~mm}$. Absolute growth rate during early seaward migration in 1995 was fastest for smolts from the lower reach of the snake River $(N=150 ;$ Mean $=1.4 \mathrm{~mm} / \mathrm{d} ; \mathrm{SD}=0.168)$ and similar between smolts from the upper reach of the snake River $(N=132$; Mean $=$ $1.3 \mathrm{~mm} / \mathrm{d} ; \mathrm{SD}=0.170)$ and the lower Clearwater River $(N=15$; Mean $=1.3 \mathrm{~mm} / \mathrm{d} ; \mathrm{SD}=0.314)($ Table 6$)$. Smolt growth rates in 1995 differed significantly (one-way ANOVA, DF = 2; MSE =0.032; $F=5.80 ; P=0.0034)$. Growth rate was significantly $(P<0.05)$ faster for smolts from the lower reach snake River, but not significantly different between smolts from the upper reach of the Snake River and lower Clearwater River. The grand mean growth rates calculated for smolts from the upper and lower reaches of the Snake River were $1.3 \pm 0.071 \mathrm{~mm} / \mathrm{d}$ and $1.3+0.159$ (Table 6), which does not support a consistent difference in growth of smolts over years between these two production areas.

\section{Discussion}

Early Life History

We found that fry emergence was complete from late April to late May in the upper reach of the Snake River, late May to early June in the lower reach of the Snake River, and early to late July in the lower Clearwater River. Fry emergence was complete by mid-May in the historic production area of the Snake River near Marsing, Idaho (Krcma and Raleigh 1970). Past and present timing of fry emergence corresponds with water temperatures during winter and early spring when eggs are incubating. The historic production area was the warmest and produced the earliest emerging fry, and the lower clearwater River is the coldest and produces the latest emerging fry. We conclude that fry emergence is later in present-day production areas than was observed in the historic production area because of differences in water temperature during winter and early spring. 
The timing of fry emergence is important because it helps to determine the environmental conditions young fall chinook salmon are exposed to throughout their freshwater life cycle. Fry emergence for other stocks of inland wild fall chinook such as the Deschutes River and John Day River stocks in Oregon, and the Hanford Reach stock of the Columbia River, Washington is typically complete between April and early-June (Oregon Department of Fish and Wildlife, unpublished data; Washington Department of Fish and Wildlife, unpublished data; Dauble et al. 1989). The presence fry in late June and early July in the lower reach of the snake River and the lower Clearwater River is later than normal for inland fall chinook salmon, and these late emerging fry must rear during mid-summer when environmental conditions are less favorable for growth.

We found that shoreline rearing by parr was complete from mid-June to early July in the upper reach of the Snake River, mid-May to mid-July in the lower reach of the snake River, and early to late July in the lower Clearwater River. Personnel of the Idaho Department of Fish and Game trapped juvenile chinook salmon in the upper reach of the snake River during the spring and summer of 1956 before the construction of the Hells Canyon Complex. Parr averaging $66 \mathrm{~mm}$ fork length $(N=119$; range 51 $85 \mathrm{~mm}$ ) were captured throughout the month of May, but none were captured in June (R. Bell, Idaho Department of Fish and Game, unpublished data). The fork lengths of parr we collected in the upper reach of the snake River (range of means $=58$ to $77 \mathrm{~mm}$ ) were similar to those measured in 1956, but the time of collection was much later in our study. We believe that parr from all three present-day production areas are present along the shorelines later in spring and early summer than before dam construction.

Parr were present along shorelines of the lower reach of the Snake River and the lower Clearwater rivers much later than parr in the upper reach of the snake River. We suspect that the parr remained in the lower reach of the snake River and the lower Clearwater River longer because fry emerged later and did not grow to smolt size (e.g., Folmar and Dickhoff 1980; Wedemeyer et al. 1980) as early as parr in the upper reach of the Snake River. Water temperature may also influence the duration of shoreline rearing by fall chinook salmon parr. Curet (1994) reported that the juvenile fall chinook salmon reared along the shoreline of Lower Granite Reservoir later into the year when the water was cool, and that dispersal from the shoreline occurred when water temperature exceeded $18.0^{\circ} \mathrm{C}$. We 
found that parr were absent along the shoreline of the snake River by the time water temperature exceeded $21.0^{\circ} \mathrm{C}$. We conclude that late fry emergence coupled with water temperatures that remain cool later into the year contributes to protracted rearing by fall chinook salmon in all three present-day production areas.

On average, only 50\% of the subyearling smolts from the upper reach of the Snake River passed Lower Granite Dam by early July. Passage was even later for subyearling smolts from the lower reach of the snake River (50\% passage by mid-July) and the lower Clearwater River (50\% passage by mid-September). Many present-day smolts pass downstream in Lower Granite Reservoir well after spring-runoff is complete, when flow in the snake River is low (e.g., 1995 range 1,068 to $2,174 \mathrm{~m}^{3} / \mathrm{s}$ ), and water temperature is over $20.0^{\circ} \mathrm{C}$ (e.g., 1995 maximum $\left.21.5^{\circ} \mathrm{C}\right)$. Mains and Smith (1956) monitored smolt passage between the present locations of Lower Granite and Little Goose dams using a trap that spanned the river's width. Smolt passage in 1954 ended by late June before the completion of spring runoff when river flow was approximately $3,400 \mathrm{~m}^{3} / \mathrm{s}$ and water temperature was approximately $16^{\circ} \mathrm{C}$, and smolt passage in 1955 ended in early July concurrent to peak spring run-off at a flow of approximately $5,000 \mathrm{~m}^{3} / \mathrm{s}$ when water temperature was approximately $13^{\circ} \mathrm{C}$ (Mains and Smith 1956). We conclude that seaward migration by subyearling fall chinook salmon smolts during the post-dam era begins later and continues longer into the summer than during the pre-dam era, and that present-day smolts are exposed to much harsher environmental conditions than their historic counterparts.

Juvenile fall chinook salmon produced in the lower reach of the Snake River and lower Clearwater River were most likely to residualize in reservoirs and complete seaward migration as yearling smolts (upper Snake River 1.5\%; lower Snake River 11.2\%; lower Clearwater River 52.1\%). To our knowledge, no other inland rivers supporting fall chinook salmon in the Columbia River basin produce juveniles that residualize in freshwater at rates as high as 52.1\%. Researchers have proposed that age at seaward migration decreases as growth rate increases (Thorpe 1989; Metcalfe and Thorpe 1990; Taylor 1990; Dickhoff et al. 1997; Beckman and Dickhoff 1998; Connor et al. In reviewb). We conclude that relatively late fry emergence coupled with relatively slow growth during rearing helps to explain why many fall chinook salmon from the lower reach of the snake River and the lower Clearwater River complete seaward migration one year later than normal as yearling smolts. 
The slope coefficients for the GM equations describing the relation between fork length and weight for fry and parr that reared along the upper and lower reaches of the snake River and the lower Clearwater River ranged from 3.146 to 3.784. The slope coefficients of length-weight regression equations reflect habitat productivity (Becker 1973). Becker (1973) reported a regression equation $\log _{10} \mathrm{Y}=-12.52+3.31 * \log _{10} \mathrm{X}$ for the Hanford Reach which supports a healthy run of wild fall chinook salmon (Dauble and Watson 1997). The slope coefficient in the Hanford Reach equation is less than 14 of 18 slope coefficients we reported. We also found that parr in the upper reach and lower reaches of the Snake River and lower Clearwater River were robustly shaped (range of $K=1.1$ to 1.2 ). We conclude that the potential for growth in weight with fork length is high in all three present-day snake River fall chinook salmon production areas.

Parr grew fastest in the upper reach of the Snake River (grand mean $=1.2+0.090 \mathrm{~mm} / \mathrm{d}$ ) compared to growth of parr in the lower reach of the snake River (grand mean $=0.9+0.113 \mathrm{~mm} / \mathrm{d}$ ) and the lower Clearwater River (grand mean $=0.8+0.0 \overline{9} 4 \mathrm{~mm} / \mathrm{d}$ ). Fall chinook salmon growth increases as water temperature increases within a range of 10.0 to $18.3^{\circ} \mathrm{C}$ (Banks et al. 1971). In 1995, warmer water temperatures during rearing explains why parr grew faster in the upper reach of the snake River (mean $=14.3^{\circ} \mathrm{C}$ ) than in the lower reach (mean $\left.=13.3^{\circ} \mathrm{C}\right)$. However, parr in the lower Clearwater River in 1995 were exposed to the warmest water temperatures during rearing (mean $=15.1^{\circ} \mathrm{C}$ ), but grew the slowest. Photoperiod, on the other hand, was increasing when parr were rearing in the upper reach of the snake River and decreasing when parr were rearing in the lower clearwater River. Thorpe et al. (1989) concluded that growth of Atlantic salmon Salmo salar parr decreases soon after day length begins to decline. We conclude that parr from the upper reach of the Snake River had the highest growth rates because fry emergence is early enough to allow parr to rear during periods of increasing day length, and water temperatures in the upper reach are warmer and more favorable for growth.

Growth rate for fish that successfully smolted and began early seaward migration was rapid each year regardless of production area (range 0.9 to $1.4 \mathrm{~mm} / \mathrm{d}$ ), and smolts collected after passing Lower Granite Dam averaged from 112 to $151 \mathrm{~mm}$ fork length with conditions factors ranging from 1.1. to 1.4. Growth rate reported for subyearling chinook salmon rearing in 
productive estuaries ranged from 0.4 to $1.3 \mathrm{~mm} / \mathrm{d}$ (Healey 1980; Kjelson et al. 1982), and smolts collected in the Snake River from April to June before dam construction averaged 83- to 103$\mathrm{mm}$ fork length. We conclude that parr that successfully smolt continue to grow rapidly both in length and weight during the period of time required to pass downstream in the impounded lower Snake River.

\section{Management Implications}

Construction of the Hells Canyon Complex reduced the production potential of the Snake River basin for fall chinook salmon. Spawners were displaced from the historic production area of the Snake River near Marsing, Idaho, which was warmer during egg incubation and rearing than any present-day production area. Consequently, young fall chinook salmon from present-day production areas emerge, rear, and begin seaward migration later than was observed for fall chinook salmon in the historic production area. Releases of cool reservoir water from the Hells Canyon Complex may also keep water temperatures in the upper and lower reaches of the snake River cooler longer into the spring and summer than before dam construction, thereby further delaying fry emergence and prolonging shoreline rearing.

Construction of Dworshak Dam and releases of water from Dworshak Reservoir made the lower Clearwater River more suitable for fall chinook salmon. There is no conclusive evidence that the lower Clearwater River ever supported fall chinook salmon, and based on the early life history timing and growth statistics we reported, it is still marginal habitat even though it is warmer than before construction of Dworshak Dam. In some years, the lower Clearwater River produces juveniles that have a "stream-type" (Healey 1991) early life history, opposed to the the typical "ocean-type" (Healey 1991) early life history of inland fall chinook salmon. Rates of residualism as high as 85.7\% in 1994 may be an unintended result of releasing cool water from Dworshak Reservoir for summer flow augmentation. Large volumes (approximately $609 \mathrm{~m}^{3} / \mathrm{s} / \mathrm{d}$ ) of $8.2^{\circ} \mathrm{C}$ water released in July, 1994 decreased water temperatures in the lower Clearwater River from 19.5 to $8.8^{\circ} \mathrm{C}$. This $10.7^{\circ} \mathrm{C}$ drop probably worked in concert with decreasing day length to cause the high rate of residualism by decreasing growth of parr that were still rearing and had not reached smolt size. In contrast to 1994, smaller volumes (approximately $381 \mathrm{~m}^{3} / \mathrm{s} / \mathrm{d}$ ) of $10.8^{\circ} \mathrm{C}$ water released from Dworshak Reservoir in July and August of 1995 resulted in a drop from 19.8 to $13.0^{\circ} \mathrm{C}$, and only $6.3 \%$ of fish 
from the lower Clearwater River residualized and completed seaward migration as yearling smolts.

Construction of Lower Granite Dam, and the seven other mainstem dams located downstream, reduced the production potential of the Snake River basin for fall chinook salmon. To reach the sea, present-day smolts pass from the relatively high velocity waters of the snake and Clearwater rivers into the relatively low velocity waters of downstream reservoirs. Fall chinook salmon smolts migrate downstream faster in high velocity water than in low velocity water. Radio-tagged wild snake River fall chinook salmon smolts migrated downstream over 26 times faster in the upper end of Little Goose reservoir which includes a short reach of high velocity water, than in the relatively low velocity water in the forebay of Little Goose Dam (Venditti et al. 2000). Venditti et al. (2000) concluded that the reduction in downstream migration rate was caused by decreased water velocity in the dam forebay.

In summary, the construction and operation of dams eliminated adult snake River fall chinook salmon passage to the most productive habitat, changed the water temperature regime of the remaining habitat and thereby the rate at which early life history events proceed, and then impounded the migration route thereby extending the time it takes smolts to reach the sea. As a direct consequence of dam construction, present-day snake River fall chinook salmon smolts pass downstream in reservoirs during mid-to-late summer when river conditions are unfavorable for survival. The snake River fall chinook salmon population was listed for protection under the Endangered species Act in 1992 (NMFS 1992), thus prompting large-scale efforts such as summer flow augmentation to increase downstream migration rates and passage survival of smolts (NMFS 1995). Preliminary findings suggest that summer flow augmentation increases smolt survival to Lower Granite Dam (Connor et al. 1998). A better understanding of the efficacy of summer flow augmentation will be required to evaluate the potential for snake River fall chinook salmon recovery in the presence of dams. 


\section{References}

Banks, J. L., L. G. Fowler, and J. W. Elliot. 1971. Effects of rearing temperature on growth, body form, and hematology of fall chinook fingerlings. The Progressive Fish Culturist 33:20-26.

Becker, C. D. 1973. Food and growth parameters of juvenile chinook salmon, Oncorhynchus tshawytscha, in Central Columbia River. Fishery Bulletin 71:387-400.

Beckman, B. R., and W. W. Dickhoff. 1998. Plasticity of smolting in spring chinook salmon: relation to growth and insulin-like growth factor-I. Journal of Fish Biology $53: 808-826$.

Connor, W. P., H. L. Burge, and D. H. Bennett. 1998. Detection of subyearling chinook salmon at a snake River dam: Implications for summer flow augmentation. North American Journal of Fisheries Management 18:530-536.

Connor, W. P., R. K. Steinhorst, and H. L. Burge. 2000 . Forecasting survival and passage for migratory juvenile salmonids. North American Journal of Fisheries Management $20: 650-659$.

Connor, W. P. and several coauthors. In reviewa. Run Composition and Early Life History Attributes of Wild Subyearling Chinook Salmon Recaptured after Migrating Downstream Past Lower Granite Dam. Submitted to Northwest Science, 20 October, 2000.

Connor, W. P., T. C. Bjornn, H. L. Burge, and A. R. Marshall. In reviewb. The role of rapid growth on seaward migration by wild subyearling spring chinook salmon in the snake River. Submitted to Transactions of the American Fisheries Society, 5 October, 2000 .

Curet, T. S. 1994. Habitat use, food habits and the influence of predation on subyearling chinook salmon in Lower Granite and Little Goose reservoirs, Washington. Master's thesis. University of Idaho, Moscow.

Daniel, W. W. 1978. Applied nonparametric statistics. Houghton Mifflin Company, Boston, Massachusetts. 
Dauble, D. D., T. L. Page, and R. W. Hanf, Jr. 1989. Spatial distribution of juvenile salmonids in the Hanford Reach, Columbia River. Fishery Bulletin 87:775-790.

Dauble, D.D., and D.G. Watson. 1997. Status of fall chinook salmon populations in the mid-Columbia River, 1948 to 1992. North American Journal of Fisheries Management $17: 283-300$.

Dickhoff, W. W., B. R. Beckman, D. A. Larsen, C. Duan, and S. Moriyama. 1997. The role of growth in endocrine regulation of salmon smoltification. Fish physiology and biochemistry 17: 231-236.

Folmar, L. C., and W. W. Dickhoff. 1980. The parr-smolt transformation (smoltification) and seawater adaptation in salmonids a review of selected literature. Aquaculture $21: 1-37$.

Groves, P. A., and J. A. Chandler. 1999. Spawning habitat used by fall chinook salmon in the Snake River. North American Journal of Fisheries Management 19:912-922.

Hall, G. E., and M. J. Van Den Avyle, editors. 1986. Reservoir fisheries management; Strategies for the 80's. Reservoir committee, Southern Division, American Fisheries Society, Bethesda, Maryland.

Healey, M.C. 1980. Utilization of the Nanaimo River Estuary by juvenile chinook salmon, Oncorhynchus tshawytscha. Fishery Bulletin 77:653-668.

Healey, M. C. 1991. Life history of chinook salmon Oncorhynchus tshawytscha. Pages 313-393, in C. Groot and L. Margolis, editors. Pacific salmon life histories. UBC Press, Vancouver, British Columba.

Kiefer, J. 1959. K-sample analogues of the Kolomorov-Smirnov and Cramer von Mises tests. Annals of Mathematical Statistics 30:420-447.

Kjelson, M. A., P. F. Raquel, and F. W. Fisher. 1982. Life history of fall-run chinook salmon, Oncorhynchus tshawytscha, in the Sacramento-San Joaquin estuary, California. Pages 393-411, in V. S. Kennedy, editor. Estuarine comparisons. Academic Press, New York. 
Kondolf, G. M., J. C. Vick, and T. M. Ramirez. 1996. Salmon spawning habitat rehabilitation on the Merced River, California; an evaluation of project planning and performance. Transactions of the American Fisheries Society 125:899-912.

Krcma, R. F. and R. F. Raleigh. 1970. Migration of juvenile salmon and trout into Brownlee Reservoir, 1962-65. Fishery Bulletin 68: 203-217.

Mains, E. M. and J. M. Smith. 1964. The Distribution, size, time and current preferences of seaward migrant chinook salmon in the Columbia and Snake Rivers. Washington Department of Fisheries, Fisheries Research Papers 2(3):543.

Marshall, A. R., H. L. Blankenship, and W. P. Connor. 2000. Genetic characterization of naturally spawned Snake River fall-run chinook salmon. Transactions of the American Fisheries Society 129:680-698.

Matthews. G. M., G. A. Swann, and J. Ross Smith. 1977. Improved bypass and collection system for protection of juvenile salmon and steelhead trout at Lower Granite Dam. Marine Fisheries Review 39:10-14.

Metcalfe N. B., and J. E. Thorpe. 1990. Determinants of geographical variation in the age at seaward-migrating salmon Salmo salar. Journal of Animal Ecology 59:135-145.

Moffitt, C. M., B. Kynard, and S. G. Rideout. 1982. Fish passage facilities and anadromous fish restoration in the Connecticut River Basin. Fisheries $7(6): 2-11$.

NMFS (National Marine Fisheries Service). 1992. Threatened status for snake River spring/summer chinook salmon, threatened status for Snake River fall chinook salmon. Federal Register 57:78 (22 April 1992):14,653-14,663.

NMFS (National Marine Fisheries Service). 1995. Proposed recovery plan for Snake River salmon. U.S. Department of Commerce, National Oceanographic and Atmospheric Administration, Portland, Oregon.

Ott, R.L. 1993. An introduction to statistical methods and data analysis. $4^{\text {th }}$ edition. Wadsworth Publishing Company, Belmont, California. 
Park, D. L. 1969. Seasonal changes in downstream migration of age-group 0 chinook salmon in the upper Columbia River. Transactions of the American Fisheries Society 2:315-317.

Prentice, E. F., T. A. Flagg, C. S. McCutcheon, and D. F. Brastow. 1990a. PIT-tag monitoring systems for hydroelectric dams and fish hatcheries. Pages 323-334 in N. C. Parker, A. E. Giorgi, R. C. Heidinger, D. B. Jester, E. D. Prince, and G. A. Winans, editors. Fish-Marking techniques. American Fisheries Society, Symposium 7, Bethesda, Maryland.

Prentice, E. F., T. A. Flagg, and C. S. McCutcheon. 1990b. Feasibility of using implantable passive integrated transponders (PIT) tags in salmonids. Pages 317-322 in $\mathrm{N}$. C. Parker, A. E. Giorgi, R. C. Heidinger, D. B. Jester, E. D. Prince, and G. A. Winans, editors. Fish-Marking techniques. American Fisheries Society, Symposium 7, Bethesda, Maryland.

Raymond, H. L. 1979. Effects of dams and impoundments on migrations of juvenile chinook salmon and steelhead from the Snake River, 1966 to 1975. Transactions of the American Fisheries Society 98:513-514.

Ricker, W. E. 1975. Computation and interpreation of biological statstics. Bulletin 191 of the Fisheries Research Board of Canada. Ottawa.

Taylor, E. B. 1990. Environmental correlates of life-history variation in juvenile chinook salmon, Oncorhynchus tshawytscha (Walbaum). Journal of Fish Biology 37:1-17.

Thorpe, J. E., C. E. Adams, M. S. Miles, and D. S. Keay. 1989. Some influences of photoperiod and temperature on opportunity for growth in juvenile Atlantic salmon Salmo salar L. Aquaculture 82:119-126.

Thorpe, J.E. 1989. Developmental variation in salmonid populations. Journal of Fish Biology 35:295-303.

Venditti, D. A., D. W. Rondorf, and J. M. Kraut. 2000. Migratory behavior and forebay delay of radio-tagged juvenile fall chinook salmon in a lower snake River impoundment. North American Journal of Fisheries Management 20:41-52. 
Wunderlich, R. C., B. D. Winter, and J. H. Meyer. 1994. Restoration of the Elwha River ecosystem. Fisheries $19(8): 11-19$.

Wedemeyer, G. A., R. L. Saunders, and W. Craig Clarke. 1980. Environmental factors affecting smoltification and early marine survival of anadromous salmonids. Marine Fisheries Review $42(6): 3-14$.

Zar, J. H. 1984. Biostatistical analysis. $2^{\text {nd }}$ edition. Prentice-Hall, Incorporated. Englewood Cliffs, New Jersey • 


\section{CHAPTER FOUR}

Modeling Flow-Dependent Changes in Juvenile Fall Chinook Salmon Rearing Habitat and Entrapment Areas in the Hanford Reach of the Columbia River

by

Kenneth F. Tiffan, Rodney D. Garland, and Dennis W. Rondorf United States Geological Survey

Biological Resources Division

Columbia River Research Laboratory

Cook, Washington 98605, USA 


\section{Introduction}

The Hanford Reach is the only unimpounded section of the Columbia River between Bonneville Dam and the Canadian border. The remainder of the Columbia River above Bonneville Dam has been transformed into a series of reservoirs by hydroelectric development. Because the Hanford Reach maintains many of the riverine processes that no longer exist in the impounded Columbia River, it supports the largest population of fall chinook salmon Oncorhynchus tshawytscha in the Columbia River Basin (Huntington et al. 1996; Dauble and Watson 1997). Fall chinook salmon are unique in that they spawn and rear in mainstem habitats rather than in tributaries like many other salmonids. Each year the Hanford Reach produces an estimated 25-30 million natural juvenile salmon (P.G. Wagner, Washington Department of Fish and Wildlife, personal communication), which rear along shallow main-stem shorelines for 2-4 months before migrating seaward during the summer.

Upstream hydroelectric dams regulate flows through the Hanford Reach with Priest Rapids Dam at the head of the Reach exerting the greatest local influence. Changes in discharge at Priest Rapids Dam to meet power demand, termed power peaking, can cause tail-water elevations to fluctuate in excess of three vertical meters within hours (U.S. Geological Survey, gage station 12472800, unpublished data). These fluctuations can potentially change the amount of rearing habitat available to juvenile fall chinook salmon on a daily and hourly basis. The repeated drying and rewetting of shoreline substrates resulting from flow fluctuations may also limit the production of macroinvertebrates, which juvenile fall chinook salmon use as food (Becker 1973; Dauble et al. 1980; Cushman 1985; Gislason 1985). Sharp decreases in flow also strand and entrap fall chinook salmon when water rapidly recedes from low-gradient shoreline habitats (Wagner et al. 1999), which can result in significant mortality of young salmon.

Since the production of juvenile fall chinook salmon in the Hanford Reach is partially dependent upon rearing habitat quality and quantity, it is important to understand the influences of annual and daily variations in discharge. Currently there is no estimate of the area of rearing habitat available to juvenile fall chinook salmon in the Hanford Reach, nor is there an understanding of how this area varies with changes in discharge. To minimize the stranding and entrapment of fish stemming from water level fluctuations, fishery managers have limited flow fluctuations at Priest Rapids Dam to $\pm 566 \mathrm{~m}^{3} / \mathrm{s}$ 
when no spill is occurring, and to $\pm 850 \mathrm{~m}^{3} / \mathrm{s}$ when the dam is spilling water at average weekly flows $<4,814 \mathrm{~m}^{3} / \mathrm{s}$. The objective of this study was to quantify the effects of flow fluctuations on the area of juvenile fall chinook salmon rearing habitat and entrapment areas.

\section{Study Area}

The Hanford Reach extends $90 \mathrm{~km}$ from Richland, Washington upstream to Priest Rapids Dam (Figure 1). We restricted our study to a 33-km area between river kilometers (Rkm) 572 and 605 (measured from the river mouth). This area supports large numbers of rearing juvenile fall chinook salmon and contains a range of geomorphic and hydraulic features. We further divided this area into three reaches. The lower reach was located between Rkm 572 and 582 and was characterized by relatively simple, linear shorelines. The middle reach was located between Rkm 582 and 594 and was characterized by large sloughs and small island complexes. The upper reach was located between Rkm 594 and 605 and was characterized by large islands and steep bluffs on the north side of the river.

\section{Methods}

\section{Riverbed bathymetry}

We required a high-resolution, digital elevation model of the study area for two-dimensional hydraulic modeling and a Geographic Information System (GIS)-based analysis of juvenile fall chinook salmon rearing habitat. We conducted an airborne LIDAR (Light Distance and Ranging) survey of $33 \mathrm{~km}$ of the Hanford Reach between Rkm 572 and 605 during late July, 1998 . LIDAR can produce highly accurate elevation data over a large area and has the ability to collect data both above and below the water surface (Guenther et al. 1996; Lillycrop et al. 1996; Parson et al. 1996). LIDAR operates on principles similar to SONAR except that the distance to an object is determined using a laser instead of sound. A LIDAR surveying unit was attached to the bottom of a helicopter whose position and altitude were determined using a kinematic global positioning system (GPS) . Kinematic GPS base stations were established to reference all data to known elevations and geographic positions. Surveys were flown at an altitude of $200 \mathrm{~m}$ to obtain a density of one sample

point for every $16 \mathrm{~m}^{2}$. Horizontal accuracy of positions was < $\mathbf{3}$ $\mathrm{m}$, and vertical accuracy was $< \pm 15 \mathrm{~cm}$ (Lillycrop et al. 1996). 


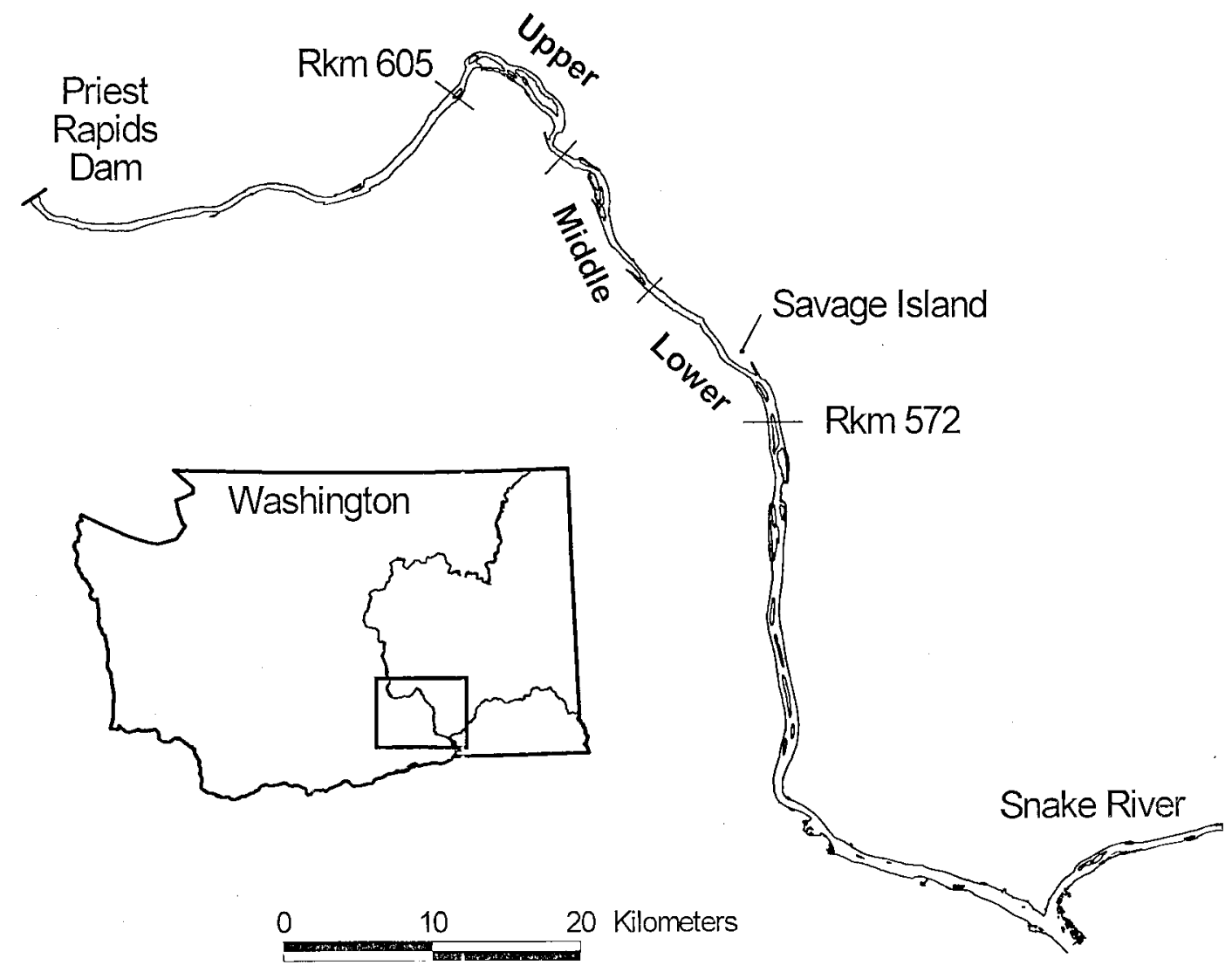

Figure 1.-The Hanford Reach of the Columbia River in Washington showing the river kilometers that delineated our study area along with the divisions between the lower, middle, and upper reaches. 
We limited our LIDAR survey to shoreline areas because they contain important rearing habitats for juvenile fall chinook salmon. We surveyed the area between shorelines created at flows of $1,416 \mathrm{~m}^{3} / \mathrm{s}$ and $11,328 \mathrm{~m}^{3} / \mathrm{s}$, which were determined from a one-dimensional hydraulic model (MASS1) developed for the Hanford Reach (Battelle Pacific Northwest Laboratory, unpublished data). Flows are typically within this range during the juvenile fall chinook salmon rearing period. We had hydrosystem operators reduce Columbia River flows to $1,416 \mathrm{~m}^{3} / \mathrm{s}$ in the Hanford Reach during our LIDAR survey to dewater as much of the river channel as possible to improve data quality. Our LIDAR survey intentionally did not include the east side of Savage Island (Figure 1) because water only flows there at very high discharges and it is usually unavailable to juvenile fall chinook salmon.

The LIDAR data, which contained over 2.2 million riverbed points, was put into a GIS to create a bathymetric coverage of the study area. Since dense vegetation such as bushes and trees cause false elevations in LIDAR data, we manually removed these from the data set and interpolated ground elevations for those areas. Video records collected during the survey confirmed the locations of dense vegetation. Because our survey did not cover the center of the river channel, we completed our bathymetric coverage using depth data collected along cross sections spaced every $0.4 \mathrm{~km}$ throughout the study area (U.S. Army Corps of Engineers, unpublished data). The combined riverbed topographies were used to create a GIS raster grid coverage with a uniform $25 \mathrm{~m}^{2}$ cell size. The positional and elevation components of each cell were then output to a file as a list of points for use in hydrodynamic modeling.

Hydrodynamic modeling

Depth-averaged water velocities were estimated for the Hanford Reach study area under a range of discharges likely to be encountered by rearing fall chinook salmon. We modeled water velocities at steady-state flows ranging from 1,416 to 11,328 $\mathrm{m}^{3} / \mathrm{s}$ in $283 \mathrm{~m}^{3} / \mathrm{s}$ increments using a two-dimensional hydrodynamic model (RIVER_2D; Ghanem et al. 1996). This model applies a twodimensional finite-element method to solve the shallow-water flow equations. Model inputs included riverbed topography with geographic position, elevation, and substrate roughness (height) information, as well as the inflow discharge and the watersurface elevation at the downstream end of the modeled area. We used a substrate roughness of $0.1 \mathrm{~m}$ for each riverbed point 
because the bed surface within our study area was generally smooth.

Position, elevation, and riverbed substrate roughness data were then used to create a triangulated mesh of points, or nodes $(N=68,444)$, for use in the hydrodynamic model. After the computational mesh was generated and smoothed, an inflow discharge $\left(\mathrm{m}^{3} / \mathrm{s}\right)$ was assigned to the upper end of the modeled area, and a corresponding water-surface elevation was assigned to the downstream end. Downstream water-surface elevations at steady-state flows were obtained from the MASS1 one-dimensional hydraulic model. Using the constraints of inflow discharge and downstream water-surface elevation, the hydrodynamic model produced water depth, water-surface elevation, velocity, and flow direction values for each node.

We validated the velocity outputs from the hydrodynamic model using empirical data collected with an acoustic Doppler current profiler (ADCP). We collected velocity data along cross sections at two locations at flows of $4,246 \mathrm{~m}^{3} / \mathrm{s}$ and $6,230 \mathrm{~m}^{3} / \mathrm{s}$. One cross section was located at Rkm 581 where the river channel was relatively simple, and the other was at Rkm 583 downstream of a large slough where the channel was more complex. The cross section at Rkm 583 was moved $0.4 \mathrm{~km}$ downstream when the flow was $4,246 \mathrm{~m}^{3} / \mathrm{s}$ because of an island that appeared at this discharge.

We measured water velocities in bins that were 5-m long and 0.5-m deep along each cross section. The midpoint of each bin was georeferenced using a GPS. Bin velocities were averaged to determine the water column velocity at each bin location. Velocities at each cross section were measured 10 times at each site and flow to capture the variation caused by water turbulence. Polynomial regression was then used to fit the best lines to the average water column velocities measured by the ADCP (SAS 1998). Measured water velocities were graphically compared to those predicted by the model at each site and flow.

GIS

Water velocities and depths derived from the RIVER_2D hydrodynamic model for each modeled flow were put into a raster format in a GIS. Both of these habitat metrics were interpolated to $16-\mathrm{m}^{2}$ cell grids using an inverse distance weighted (IDW) interpolator (Watson 1994; ESRI 1998). A 16-m² cell size was selected to maintain consistency with the LIDAR cell sizes. The slope of each $16-\mathrm{m}^{2}$ LIDAR cell was calculated in 
GIS as a grid-based two-dimensional slope and was expressed as a percent (Burrough 1986; ESRI 1998).

Rearing habitat

Data collection.-We determined juvenile fall chinook salmon use of shoreline habitats in the Hanford Reach using point electroshocking (Persat and Copp 1990) in 1994 and 1995. We sampled from late April through May when juvenile fall chinook salmon were most abundant. We stratified our sampling to include different habitat combinations, avoid duplication of effort, and minimize sample bias. Three matrices were constructed with different combinations of habitat variables to guide sampling and included (1) velocity $x$ depth, (2) velocity $x$ substrate, and (3) depth $x$ substrate. Targeted velocities ranged from 0 to $>0.4 \mathrm{~m} / \mathrm{s}$ and were divided into $0.1-\mathrm{m} / \mathrm{s}$ categories. Depths ranged from 0 to $>3.3 \mathrm{~m}$ and were divided into $0.6-\mathrm{m}$ categories. Substrate sizes ranged from $<1 \mathrm{~mm}$ to $>256$ $\mathrm{mm}$ and were divided into five categories: <1 $\mathrm{mm}, 1-4 \mathrm{~mm}, 4-16$ $\mathrm{mm}, 16-256 \mathrm{~mm}$, and $>256 \mathrm{~mm}$. Habitats were randomly selected and sampled to collect at least three observations for each matrix cell.

Data were collected using a 5.5-m electrofishing boat with two 1.0-m umbrella anode arrays and an electrical output of 2 amps at 60 pulses/s DC. We collected a sample by driving directly towards the shoreline, abruptly stopping the boat, and shocking an area for at least $8 \mathrm{~s}$. This allowed us to shock a localized, stationary area with minimal forewarning to fish. At the end of the shock, a buoy was set to mark the area where fish were observed, or the center of the shocked area if fish were absent. Fish were visually identified and enumerated by counting stunned fish and collecting a sample of the stunned fish with dipnets (Crozier and Kennedy 1994). We hereafter refer to the number of fish caught and observed as "catch".

Physical characteristics were measured at each site to describe habitat. Water velocity was measured to the nearest $0.01 \mathrm{~m} / \mathrm{s}$ using a current meter at the point of shock and at $15 \mathrm{~m}$ from shore. Water depth and flow direction were collected concurrently with velocity measurements. Distance of the point of shock to the shoreline was measured to the nearest $1 \mathrm{~cm}$. At the point of shock, substrate size was visually assessed based on a Wentworth classification modified from Orth (1983).

Logistic regression.-We constructed a logistic regression model to predict the probability, $P_{i}$, of juvenile fall chinook salmon 
presence in $i$ nearshore habitat cells given habitat characteristics of each cell. $P_{i}$ can be expressed as:

$$
P_{i}=\frac{e^{g(x)}}{1+e^{g(x)}}
$$

where $g(x)$ is the linear combination of parameter estimates of the predictor variables. We only considered habitat variables that were compatible with a GIS, which included water velocity, depth, distance to shore, substrate, and lateral slope. Lateral slope was calculated by dividing the depth at the point of shock by the distance from shore and multiplying the quotient by 100 . Substrate categories were converted to design variables with fine substrate $(<1 \mathrm{~mm})$ serving as the reference category.

Because mean fish sizes did not differ by more than $7 \mathrm{~mm}$, all sampling data from 1994 and 1995 were pooled to increase sample size for model development. Fish presence was assigned a value of 0 if fish were caught or observed and 1 if $\mathrm{fish}$ were absent from samples.

Model development began by regressing fish presence against each habitat variable separately to determine if each onevariable model was significantly different from the constantonly model. This was done using the likelihood ratio test, whose statistic, $G$, is equal to minus twice the difference between the log likelihoods of the two models. This statistic was then compared to the chi-square distribution with 1 df at $\alpha=0.05$ (Hosmer and Lemeshow 1989). Habitat variables with $P$ values $<0.25$ were considered as candidates for multivariate analyses.

One of the assumptions of logistic regression regarding continuous variables is that the relationship between a predictor and the logit will be linear. This assumption was examined following the methods of Demaris (1992) for velocity and lateral slope, which were identified as significant continuous variables in univariate analyses. Because this assumption did not hold for these variables, we modeled them as design variables (Hosmer and Lemeshow 1989; Hardy 1993).

Multivariate logistic regression proceeded by estimating a model that included all variables that were significant in univariate analyses. Variables were then removed one at a time based on their Wald chi-square statistic. The importance of each variable was determined using the likelihood ratio test for the models with and without the variable. A nonsignificant 
result indicated that the variable did not contribute to the model. Significance was assumed at $P<0.05$.

The fit of our final model was evaluated using the HosmerLemeshow statistic (Hosmer and Lemeshow 1989), for which a high $P$ value, or nonsignificant result, indicates a good fit. We evaluated the performance of our logistic regression model using cross-validation. Cross-validation involves removing one observation from the data set and estimating the logistic model using the remaining observations. The probability of fish presence in the excluded observation is then estimated according to this model. This process is repeated for each observation in the data set and classifications of fish presence and absence are then tabulated. Probabilities $\geq 0.5$ were used to define fish presence. Statistical analyses were performed using SAS software (SAS 1998).

Because the prior probabilities of fish presence and absence were unequal, classification rates produced from crossvalidation were tested against those expected by chance by means of Cohen's kappa statistic (Titus et al. 1984). The value of kappa ranges from zero to one, with zero indicating no improvement over random chance and one resulting from perfect assignment. An intermediate value of kappa, such as 0.70, indicates that classification of fish presence and absence is 70\% better than a chance assignment. Ninety-five percent confidence intervals (CI) and the probability of kappa being significantly different from zero were also calculated.

Predicting the quantity of rearing habitat.-We predicted the quantity of juvenile fall chinook salmon habitat at different river discharges by analyzing the GIS data with the logistic regression model. GIS coverages were created for habitat variables that were included in our final logistic regression model. Habitat attributes of each GIS cell were used in the logistic regression model to obtain the probability of fish presence in each cell. We created a probability coverage in GIS and considered habitat cells with probabilities $\geq 0.5$ to be suitable for rearing juvenile fall chinook salmon. Because only $0.1 \%$ of all fall chinook salmon were caught in velocities greater than $0.71 \mathrm{~m} / \mathrm{s}$ and in water deeper than $1.5 \mathrm{~m}$, we set probabilities to 0 where velocities and depths exceeded these thresholds. Finally, we summed the areas of all cells with probabilities $\geq 0.5$ to determine the total amount of potential rearing area at each flow and in each reach. 
The hydrodynamic model enabled us to identify topographic depressions that were disconnected from the main river channel that could potentially entrap fish when flows decreased. We calculated the total area of disconnected pools that were created in the study area when flows were decreased by $566 \mathrm{~m}^{3} / \mathrm{s}$ and $850 \mathrm{~m}^{3} / \mathrm{s}$ from each flow modeled. As mentioned earlier, these are the daily flow decreases currently allowed by fishery managers to minimize the stranding and entrapment of juvenile fall chinook salmon.

\section{Results}

Hydrodynamic modeling and validation

All flows were successfully modeled with the RIVER_2D hydrodynamic model with the exception of $8,779 \mathrm{~m}^{3} / \mathrm{s}$ and 10,762 $\mathrm{m}^{3} / \mathrm{s}$, because of computational limitations. The water velocities predicted by the hydrodynamic model were generally within the observed variability of the ADCP data and were similar to the best-fitting polynomial regression lines. Figure 2 provides an example of the generally close agreement between observed and predicted water velocities at $\mathrm{Rkm} 581$ at $6,230 \mathrm{~m}^{3} / \mathrm{s}$. The model predicted slower near-shore water velocities at Rkm 581 on the west side of the river, but slightly higher velocities on the east side of the river. On this side of the river, water velocities were slowed by submerged vegetation that was not accounted for by the model.

Fish catch

We collected 294 point-electrofishing samples in 1994 and 1995. Fish were present in 198 of these samples and absent in the remaining 96. Catches of juvenile fall chinook salmon ranged from 0 to 1,031 fish with a median catch of 4 fish. The distribution of the number of fish caught or observed in sample sites was skewed to the left with $80 \%$ of the sites containing 35 or fewer fish (Figure 3). However, 7\% of sample sites had catches of juvenile fall chinook salmon that exceeded $100 \mathrm{fish}$. Mean fork length was $55 \mathrm{~mm}(N=57$, std=6.7) in 1994 and $45 \mathrm{~mm}$ $(N=180$, std 4.7) in 1995. Few fish were found in water faster than $0.4 \mathrm{~m} / \mathrm{s}$ or over lateral slopes steeper than $40 \%$. Fish were generally captured within $25 \mathrm{~m}$ of shore and in water shallower than $2 \mathrm{~m}$. 


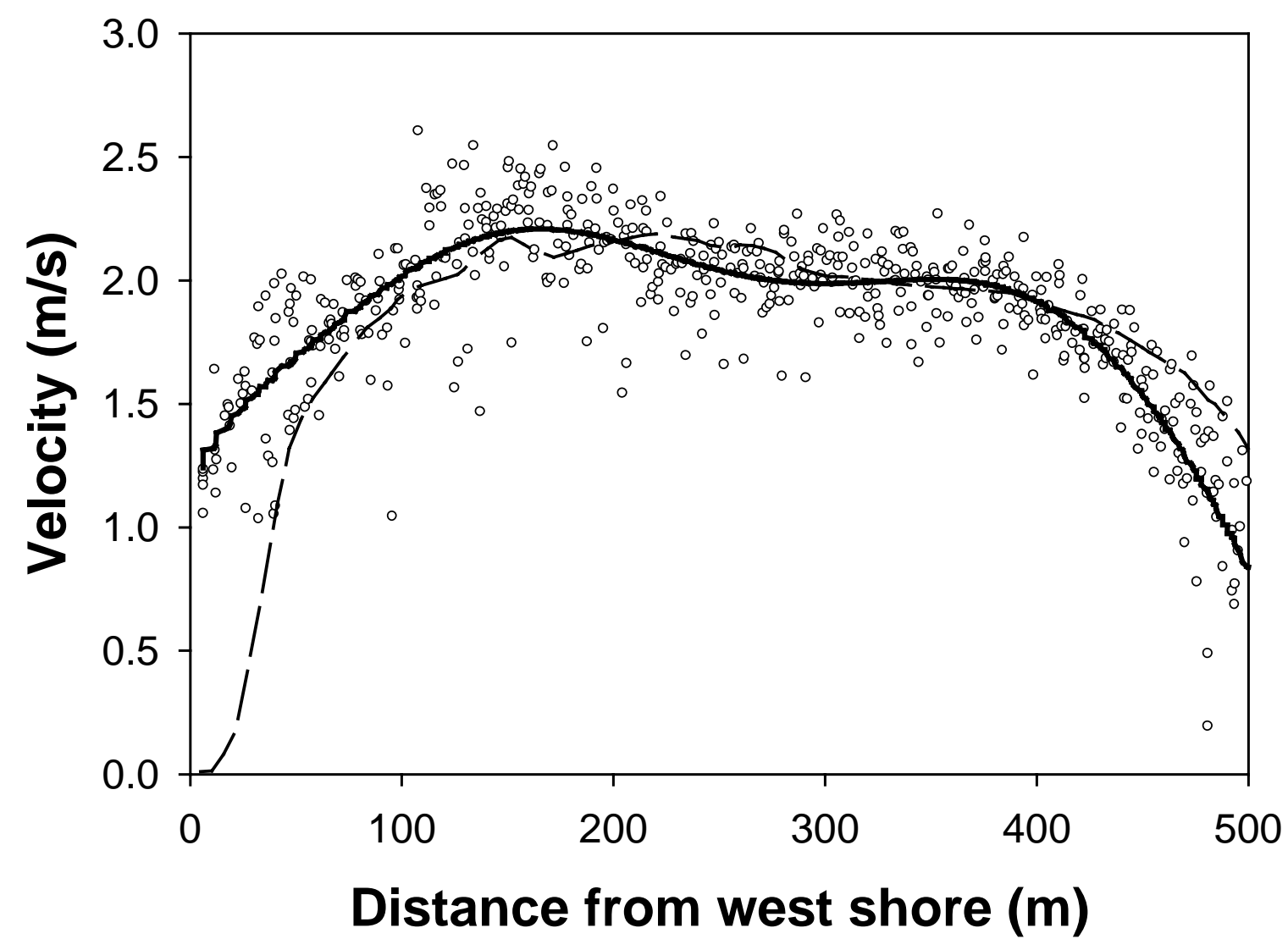

Figure 2.-Water velocities measured with an ADCP and predicted with the RIVER_2D hydrodynamic model at a flow of $6,230 \mathrm{~m}^{3} / \mathrm{s}$ at a simple channel site (Rkm 581) in the Hanford Reach of the Columbia River. Open circles represent average water column velocities measured with an ADCP for individual cross sections. The solid line represents the best-fitting polynomial regression line to the ADCP data while the broken line represents water velocities predicted by the model. The west shoreline is represented by 0 on the $x$ axis. The east shoreline shown is approximately $30 \mathrm{~m}$ from its true location because the water became too shallow to collect ADCP data with a boat. 


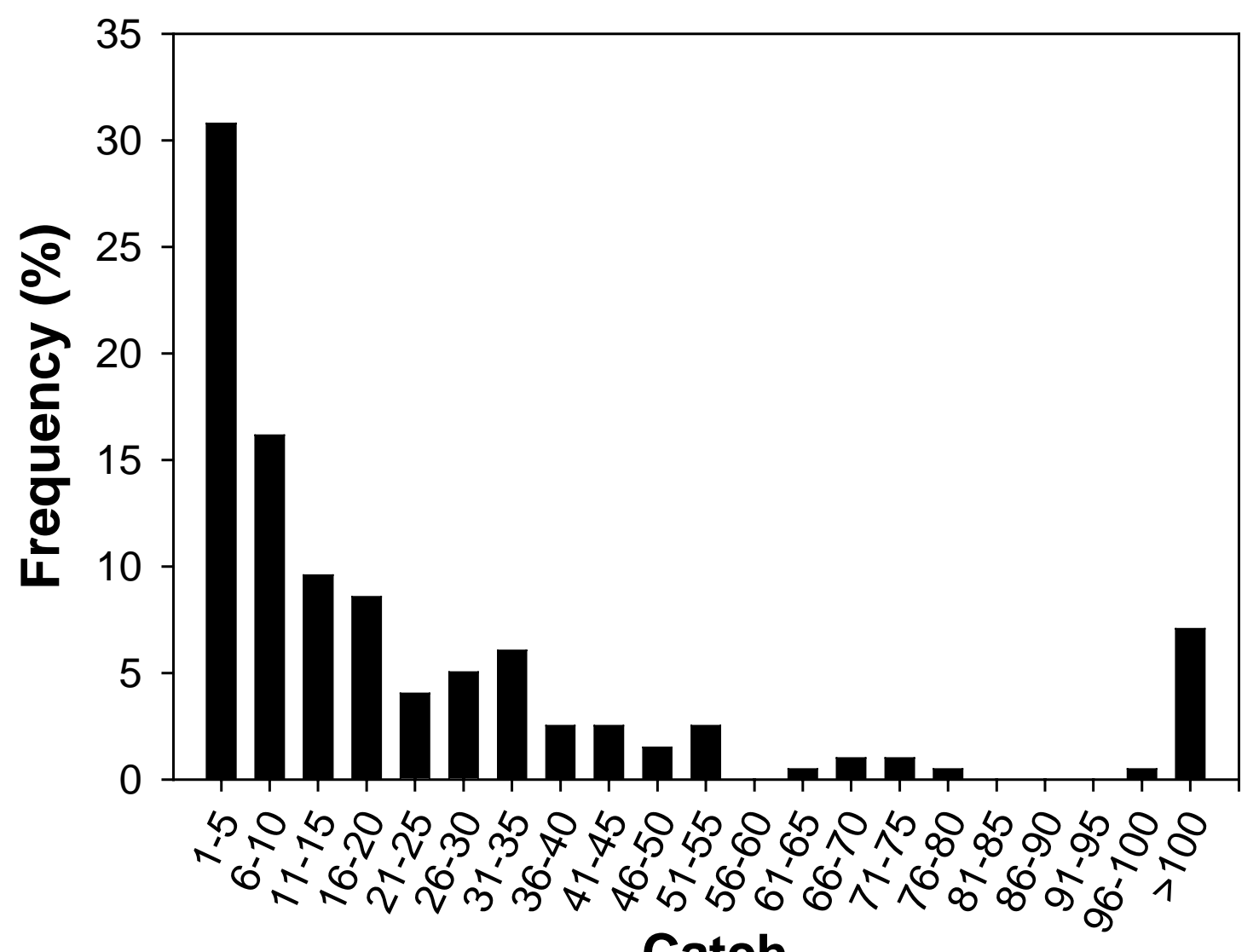

Catch

Figure 3.-Frequency distribution of numbers of juvenile fall chinook salmon caught or observed during point electrofishing in the Hanford Reach during 1994-95. 
Univariate analyses of fall chinook salmon habitat variables showed that each variable was significantly different from the constant-only model with the exception of substrate variables. Our final multivariate model included velocity and lateral slope (Table 1 ), and is expressed as:

$$
\begin{aligned}
g(x)= & -3.19+2.23 V_{1}+2.45 V_{2}+1.96 V_{3} \\
& +2.66 S_{1}+2.42 S_{2}+2.28 S_{3}+1.04 S_{4}
\end{aligned}
$$

where $V_{1-3}$ represent different categories of water velocity and $S_{1-4}$ represent different categories of lateral slope (Table 1). Because velocity and lateral slope were modeled as design variables, an individual variable will assume a value of 1 when its category contains a measure for a given habitat cell, otherwise its value will be 0 . Since our model contains only discrete design variables, there are only 20 possible probabilities that can be generated.

Lateral slope was slightly more important than water velocity in determining juvenile fall chinook salmon use of rearing habitats. As the lateral slope decreased, the odds of fish presence increased (Table 1). Slower water velocities were also associated with an increased probability of fish presence with velocities ranging from 0.1 to $0.2 \mathrm{~m} / \mathrm{s}$ producing in the highest probability of use (Table 1). The number of juvenile fall chinook salmon caught or observed in rearing habitats increased as the probability of fish presence increased (Figure 4). With the exception of three observations, catches greater than 100 fish were only associated with probabilities greater than 0.8 .

The Hosmer-Lemesshow statistic for our final model, 0.7613 $(P=0.9931,6 \mathrm{df})$, indicates a good fit to the data. The correct cross-validation classification of fish presence and absence in rearing habitats was 76\%. The correct prediction rate of fish presence was 78\%, whereas fish were absent in the remaining 22\% of the habitats predicted to contain fish (error of commission). Conversely, fish were present in 31\% of the habitats where our model predicted them to be absent (error of omission). The kappa statistic indicates that correct classifications were 41\% better than those expected by chance and that they were significantly different from zero (kappa=0.41; 95\% confidence interval $(\mathrm{CI})=0.29-0.54 ; P<0.0001)$. 
Table 1.-Summary of the final logistic regression model used to predict the probability of juvenile fall chinook salmon presence in rearing habitats in the Hanford Reach. The category of each design variable is shown with respective water velocities $>0.4 \mathrm{~m} / \mathrm{s}$ and lateral slopes $>40 \%$ serving as reference categories. The likelihood ratio of the model was 72.7 with 8 df $(P<0.0001)$.

\begin{tabular}{lcccc}
\hline $\begin{array}{c}\text { Variable } \\
\text { Intercept }\end{array}$ & $\begin{array}{c}\text { Variable } \\
\text { category }\end{array}$ & $\begin{array}{c}\text { Regression } \\
\text { coefficient }\end{array}$ & $\begin{array}{c}\text { Standard } \\
\text { error }\end{array}$ & $\begin{array}{c}\text { Odds } \\
\text { ratio }\end{array}$ \\
Velocity $\left(V_{1}\right)$ & $0-0.1 \mathrm{~m} / \mathrm{s}$ & 2.23 & 0.484 & 9.3 \\
Velocity $\left(V_{2}\right)$ & $0.1-0.2 \mathrm{~m} / \mathrm{s}$ & 2.45 & 0.543 & 11.5 \\
Velocity $\left(V_{3}\right)$ & $0.2-0.4 \mathrm{~m} / \mathrm{s}$ & 1.69 & 0.507 & 5.4 \\
Slope $\left(S_{1}\right)$ & $0-10 \%$ & 2.66 & 0.564 & 14.3 \\
Slope $\left(S_{2}\right)$ & $10-20 \%$ & 2.42 & 0.555 & 11.2 \\
Slope $\left(S_{3}\right)$ & $20-30 \%$ & 2.28 & 0.563 & 9.8 \\
Slope $\left(S_{4}\right)$ & $30-40 \%$ & $1.04^{\mathrm{a}}$ & 0.650 & 2.8 \\
\hline $\begin{array}{l}\text { Design variable } \\
\text { (P=0.1093) }\end{array}$ & $S_{4}$ did not contribute significantly to the model
\end{tabular}




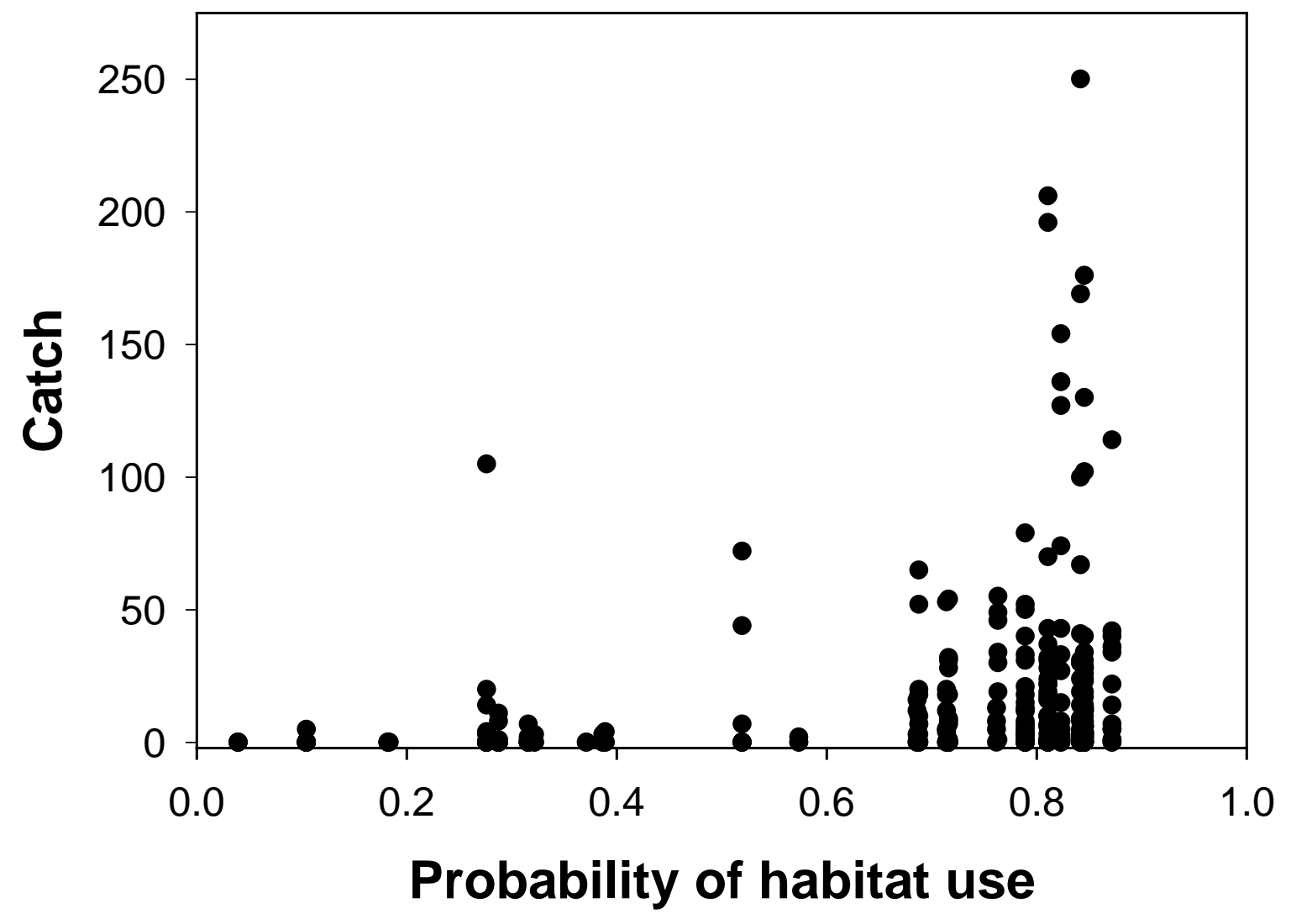

Figure 4.-The relationship between the number of juvenile fall chinook salmon caught or observed in the Hanford Reach in 199495 and their probability of habitat use as determined by logistic regression. For presentation purposes, two observations are not shown (catch=557, probability=0.57; catch $=1,031$, probability $=0.52$ ). 
Our estimates of juvenile fall chinook salmon rearing habitat varied with flow and by study reach. The amount of suitable rearing area generally decreased as flows increased, with the greatest decreases occurring as flows increased from $1,416 \mathrm{~m}^{3} / \mathrm{s}$ to about $4,814 \mathrm{~m}^{3} / \mathrm{s}$; Figure 5). The upper reach contained the most rearing area followed by the middle and lower reaches. Figure 6 provides a graphical example of rearing area at Rkm 587 displayed in GIS. The steeper shoreline on the right side of the river contained less suitable area than the islands on the left side of the river where the velocities and lateral slopes were lower.

Shoreline complexity, defined as the ratio of shoreline length to reach length, also varied by reach. The upper reach was most complex at all flows (range 5.2-5.9), as indicated by larger values, followed by the middle (range 3.7-4.5) and lower reaches (range 3.2-3.6). In addition, we summed the lengths of shoreline that contained suitable rearing habitat cells to determine what percent of the total shoreline was available to rearing fall chinook salmon. The percentage of suitable shorelines decreased as flow increased. For the entire study area, the percent of suitable shoreline ranged from 77\% at $11,328 \mathrm{~m}^{3} / \mathrm{s}$ to $97 \%$ at $1,416 \mathrm{~m}^{3} / \mathrm{s}$.

Flow fluctuations of $\pm 566 \mathrm{~m}^{3} / \mathrm{s}$ had the smallest effect on changes in the amount of juvenile fall chinook rearing area when discharges were between $3,682 \mathrm{~m}^{3} / \mathrm{s}$ and $7,080 \mathrm{~m}^{3} / \mathrm{s}$ (Figure 7). Changes ranged from -12.0 to +12.6 ha, which corresponded to $6.3 \%$ and $+6.8 \%$ of the total available rearing area, respectively. Fluctuations of $\pm 566 \mathrm{~m}^{3} / \mathrm{s}$ produced the greatest changes in the amount of rearing area when discharge was less than 3,682 $\mathrm{m}^{3} / \mathrm{s}$. Moderate, but variable, changes occurred when flows exceeded $7,080 \mathrm{~m}^{3} / \mathrm{s}$. Flow fluctuations of $\pm 850 \mathrm{~m}^{3} / \mathrm{s}$ also had the smallest effect on rearing area gains and losses when flows were between $3,965 \mathrm{~m}^{3} / \mathrm{s}$ and $6,797 \mathrm{~m}^{3} / \mathrm{s}$ (Figure 7). Changes ranged from -9.5 to +14.5 ha, which corresponded to $-5.2 \%$ and +7.9\% of the total available rearing area, respectively.

Entrapment area

The area of pools that could potentially entrap juvenile fall chinook salmon in the Hanford Reach varied by study reach and river discharge. The middle reach contained more than twice as much entrapment area at flows less than $3,965 \mathrm{~m}^{3} / \mathrm{s}$ than the lower and upper reaches (Figure 8). Most of this area was 


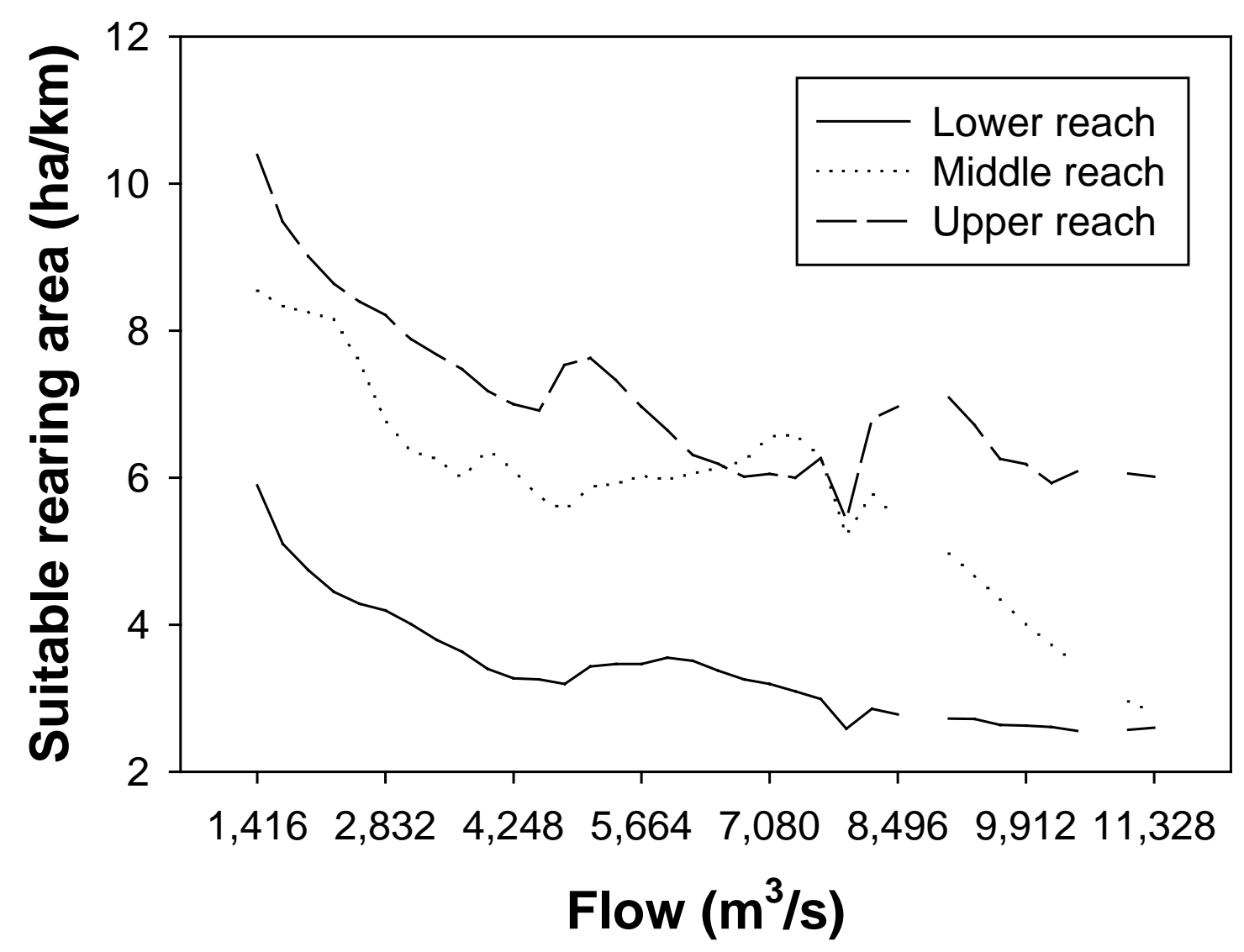

Figure 5.-The relationship between the amount of suitable rearing area for juvenile fall chinook salmon and steady-state flow in three Hanford Reach study areas. 


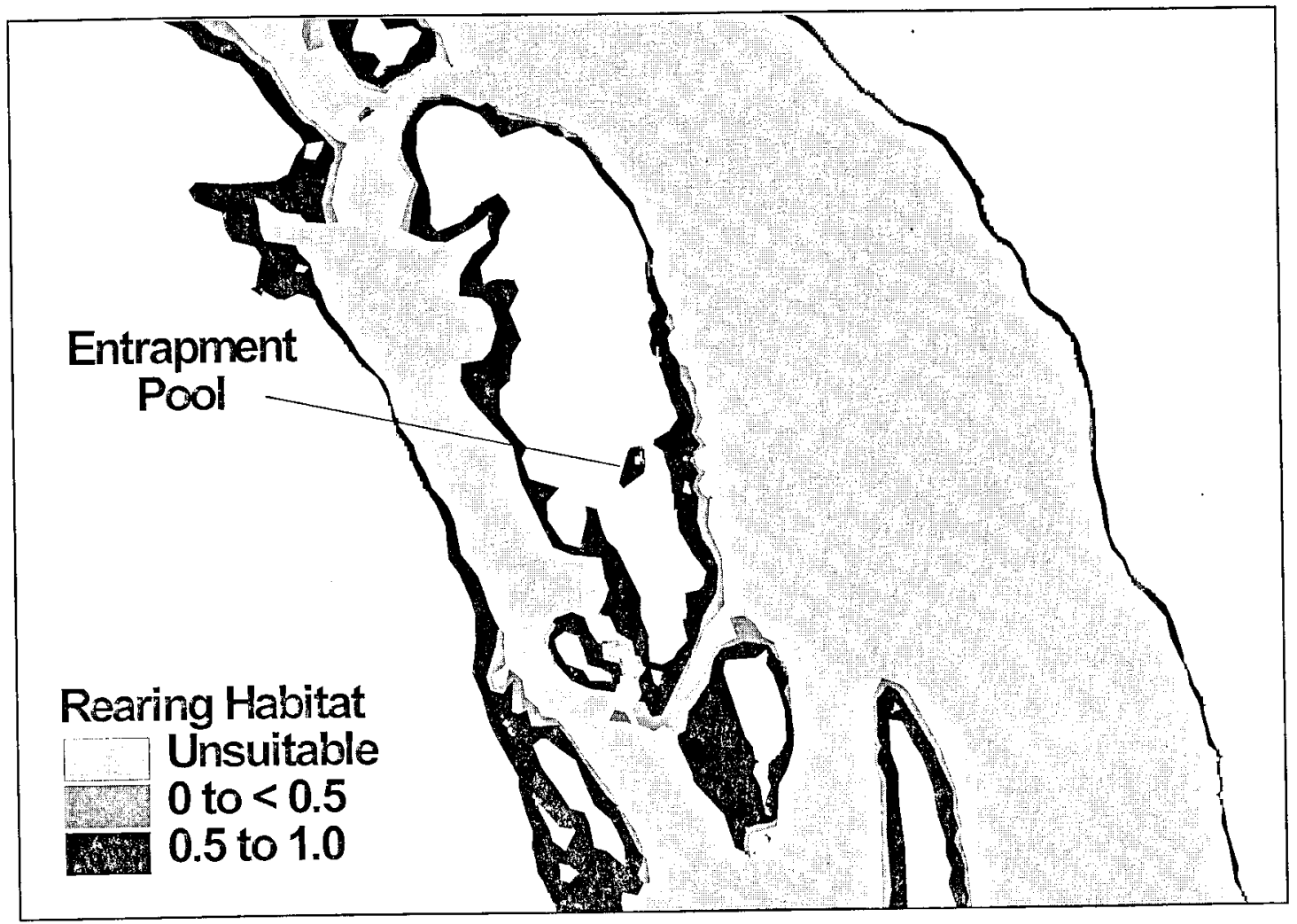

Figure 6.-A GIS display of juvenile fall chinook rearing area at Rkm 587 in the Hanford Reach of the Columbia River at a modeled flow of $4,248 \mathrm{~m}^{3} / \mathrm{s}$. Black and dark gray shaded areas are defined by the probability of fish presence in those areas with probabilities $\geq 0.5$ (black) representing suitable area. The entrapment pool shown was connected to the river channel at a flow of $5,098 \mathrm{~m}^{3} / \mathrm{s}$. 


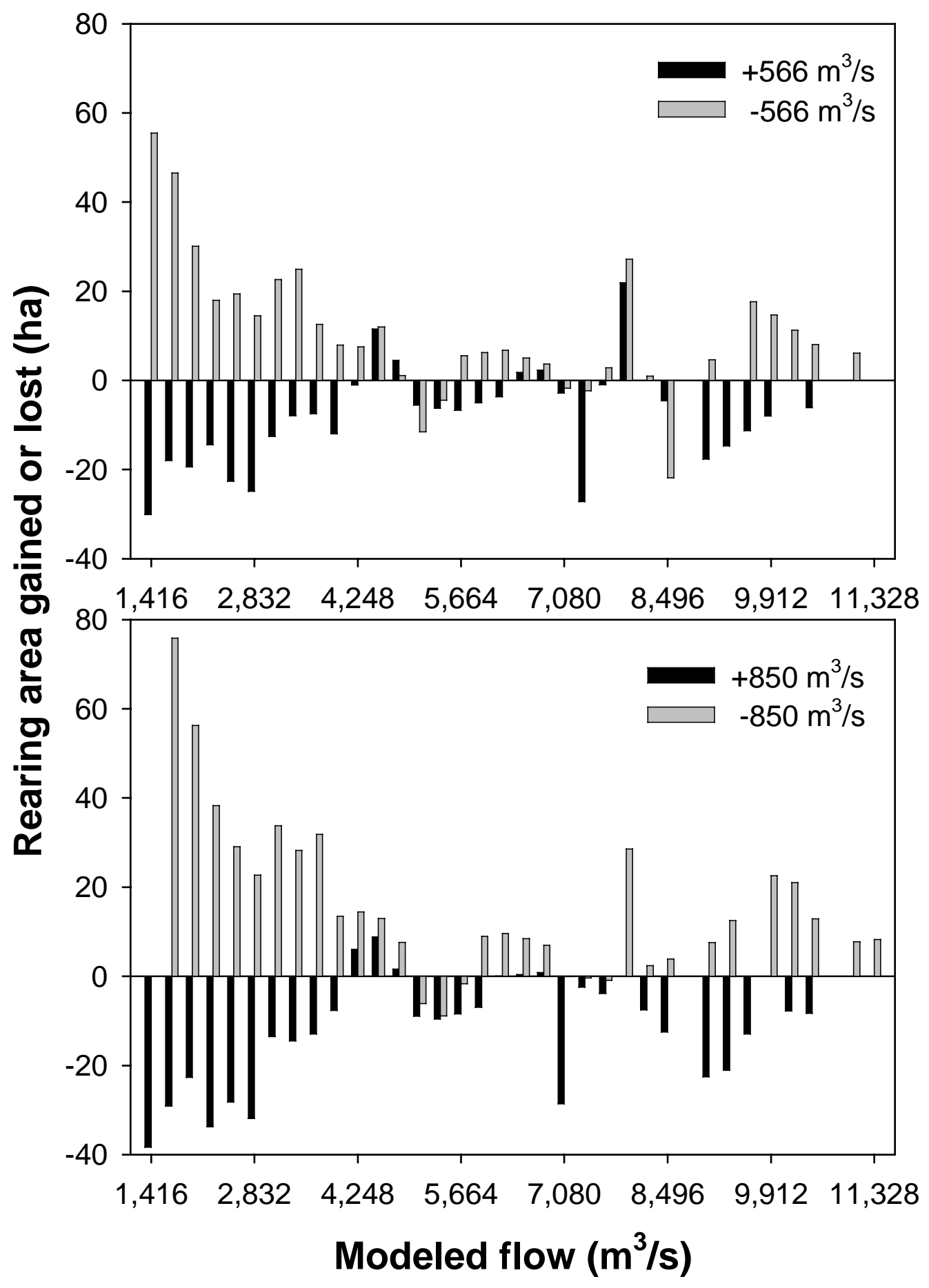

Figure 7.-Juvenile fall chinook salmon rearing area gained or lost due to $\pm 566 \mathrm{~m}^{3} / \mathrm{s}$ (top panel) and $\pm 850 \mathrm{~m}^{3} / \mathrm{s}$ (bottom panel) changes from modeled flows in the Hanford Reach. 


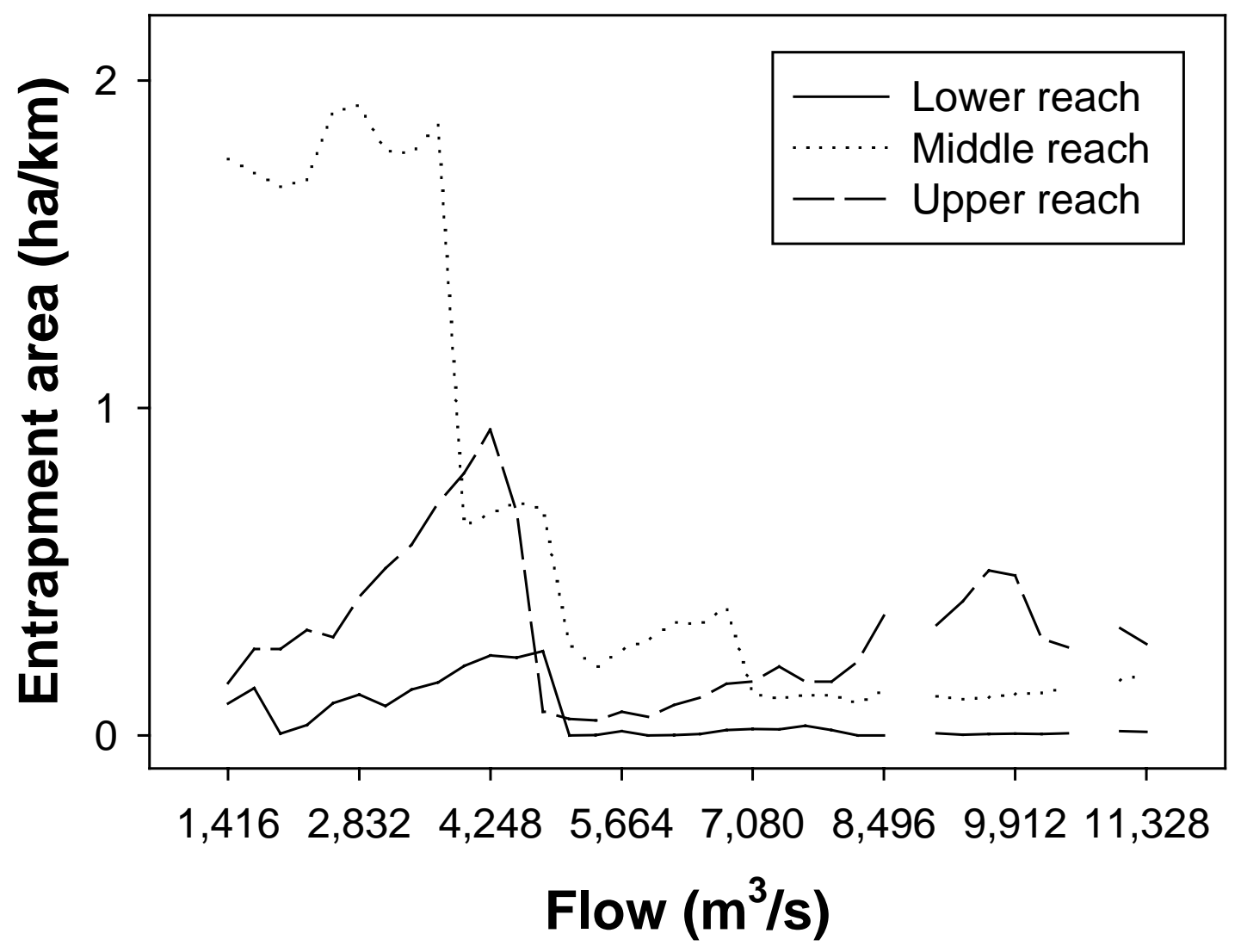

Figure 8.-Potential entrapment area created at different steady-state flows in three Hanford Reach study areas. 
formed by the separation of a large slough from the main river channel in an island complex known as the $100 \mathrm{~F}$ area. The amount of entrapment area in the middle and lower reaches was much less at flows exceeding $4,814 \mathrm{~m}^{3} / \mathrm{s}$, and in the upper reach at flows greater than $4,531 \mathrm{~m}^{3} / \mathrm{s}$. The lower reach generally had the least amount of entrapment area and showed no great variations with flow. When flows exceeded $7,080 \mathrm{~m}^{3} / \mathrm{s}$, the upper reach contained more entrapment area than other reaches, primarily in the vicinity of Rkm 593.

We determined the amount of entrapment area formed from 566 $\mathrm{m}^{3} / \mathrm{s}$ and $850 \mathrm{~m}^{3} / \mathrm{s}$ decreases from each river flow modeled. A 566 $\mathrm{m}^{3} / \mathrm{s}$ drop in flow produced the greatest amount of entrapment area at flows ranging from $3,965 \mathrm{~m}^{3} / \mathrm{s}$ to $5,381 \mathrm{~m}^{3} / \mathrm{s}$ (Figure 9). For example, a decrease in flow from $5,098 \mathrm{~m}^{3} / \mathrm{s}$ to $4,531 \mathrm{~m}^{3} / \mathrm{s}$ produces a net increase of 15.7 ha of entrapment area. Flow reductions of $850 \mathrm{~m}^{3} / \mathrm{s}$ resulted in the creation of the most entrapment area between flows of $5,381 \mathrm{~m}^{3} / \mathrm{s}$ and $5,664 \mathrm{~m}^{3} / \mathrm{s}$ (Figure 9).

\section{Discussion}

Physical habitat models, such as PHABSIM (Bovee 1982), are commonly used in habitat assessments. PHABSIM incorporates onedimensional flow models and biological models (HSI; Habitat Suitability Indexes) to predict habitat availability in terms of weighted usable area (WUA). However, PHABSIM has the drawbacks of simplistic hydraulic assumptions and often requiring high effort (Ghanem et al. 1996; Kondolf et al. 2000). Technological advances in remote sensing and computers make it possible to use more refined tools (e.g., two-dimensional hydrodynamic models, GIS) to provide more detailed and realistic habitat assessments with less effort (Leclerc et al. 1995).

The high-resolution bathymetry collected with LIDAR enabled us to use a two-dimensional hydrodynamic model and a GIS to quantify the amount of juvenile fall chinook salmon rearing area over a broad, complex geographic area at 34 different discharges in the Hanford Reach. Recently, Guay et al. (2000) used a twodimensional hydrodynamic model in conjunction with both HSI and logistic regression models to predict the distribution of juvenile Atlantic salmon Salmo salar in the sainte-Marguerite River, Quebec. Leclerc et al. (1995) also demonstrated the utility of using a two-dimensional hydrodynamic model with HSIs to model juvenile Atlantic salmon habitat. 


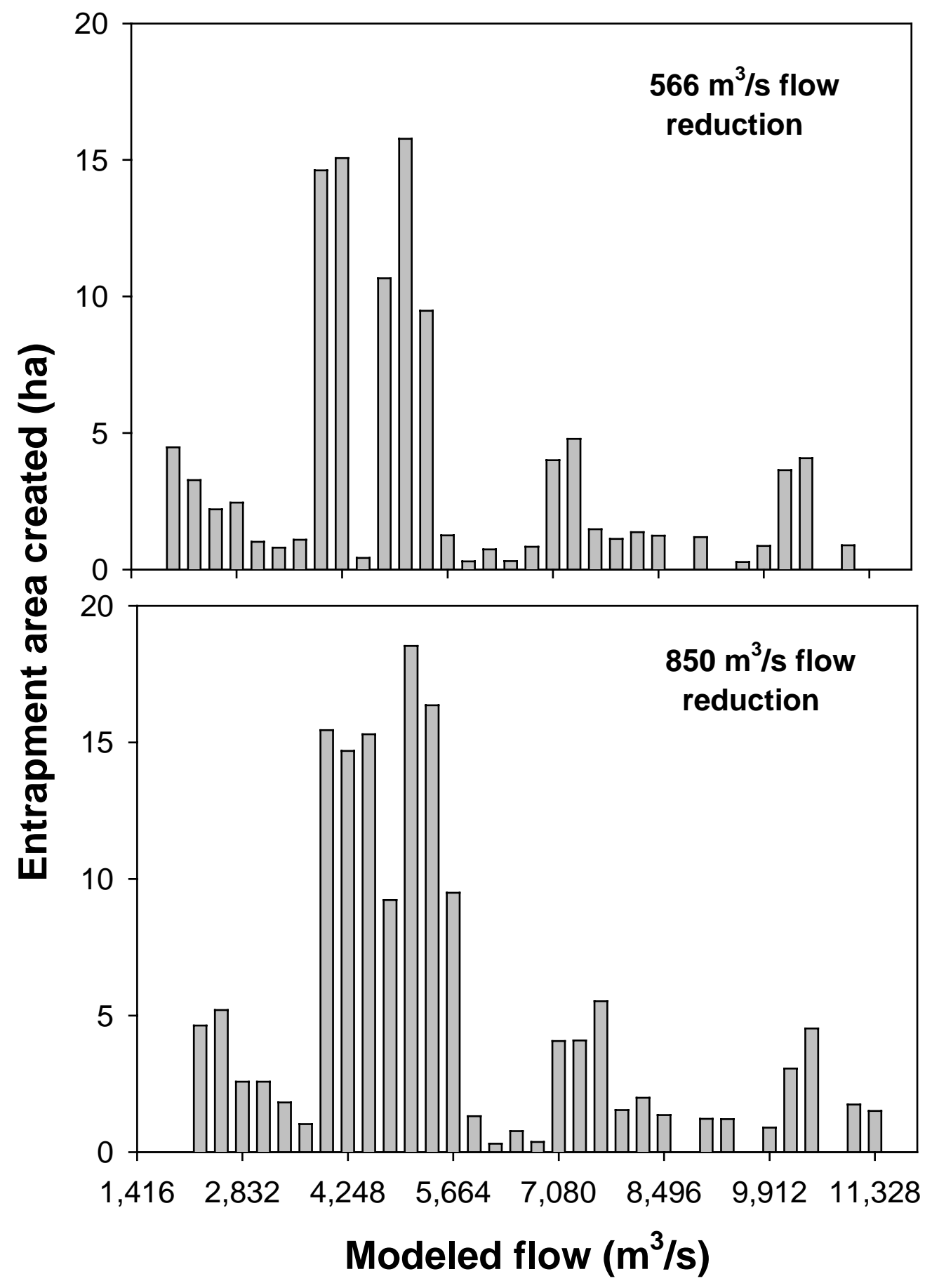

Figure 9.-Net entrapment area created from $566 \mathrm{~m}^{3} / \mathrm{s}$ (top panel) and $850 \mathrm{~m}^{3} / \mathrm{s}$ (bottom panel) reductions from modeled flows in the Hanford Reach. Bar heights are additive in 566 and $850 \mathrm{~m}^{3} / \mathrm{s}$ increments, respectively. 
Two-dimensional hydrodynamic models have considerable advantages over one-dimensional models in that they can be used in complex channels to more accurately characterize water velocities (Ghanem et al. 1996). The velocities we measured with the ADCP agreed closely with the water velocities estimated by the RIVER_2D hydrodynamic model except at the shoreline in certain areas. Lower than observed shoreline water velocities estimated by the model at ADCP cross sections was most likely due to the model requiring a zero velocity at the shoreline and the coarseness of our computational mesh near shore. Although this condition exists in many areas of the Hanford Reach, some steeper shorelines had flowing water right at the shore. As such, we may have overestimated the amount of rearing habitat in those areas, especially if the lateral slope was suitable. Conversely, near-shore water velocities may have been overestimated in areas where submerged vegetation slowed the water current. In spite of these limitations, we were able to make comparisons of the relative amount of rearing habitat available at different flows.

We found water velocity to be an important factor influencing the habitat selection of juvenile chinook salmon, which is consistent with the findings of others (Lister and Genoe 1970; Everest and Chapman 1972; Rubin et al. 1991; Key et al. 1996). The water velocities used by Hanford Reach fall chinook salmon were similar to those reported for chinook salmon in large rivers (Glova and Duncan 1985; Garland and Tiffan 1999) and smaller streams (Everest and Chapman 1972; Rubin et al. 1991). Low velocity habitats reduce the amount of energy required for fish to maintain their position in the current.

Although the aforementioned authors reported water depth to be an important habitat variable, depth by itself was not an important variable in our study. Instead, fall chinook salmon presence was associated with lateral slope, which incorporates water depth. Areas of low velocity and lateral slope near shore are typically warmer than the main channel and may maximize growth of juvenile fall chinook salmon.

Our logistic regression model performed better at predicting the presence of juvenile fall chinook salmon in rearing habitats than predicting their absence. However, the observed absence of fish in a habitat cell where their presence was predicted with high probability does not necessarily imply that the habitat is unsuitable or not used. We have routinely observed the spatial and temporal movement of schools of juvenile fall chinook through shoreline habitats in the Hanford 
Reach. This behavior makes it probable that sampling suitable habitat may result in a zero catch. By the same logic, fish presence does not undoubtedly suggest that habitat is suitable. Considering that fish were absent in only one third of our samples, our sample size may not have been large enough to adequately define the habitat conditions that contribute to fish absence. As such, predicting fish absence where they were present makes our model estimates of the amount of suitable rearing area conservative.

The amount of fall chinook salmon rearing area in the Hanford Reach increased as flow decreased due to shallower nearshore slopes and reduced water velocities. In contrast, at higher flows water velocities were generally greater and the shorelines were located on steeper banks due to fuller river channels. In addition, many of the islands that provided rearing area at low flows were submerged at higher discharges.

Our estimates of the amount of rearing area show that the production of juvenile fall chinook salmon in the Hanford Reach may be influenced by annual variations in flow. Low-flow years may support more rearing fish in the Hanford Reach than high flow years because of the increase in available habitat. For example, the mean flow for May (typically the month of peak abundance) 1992 was $3,993 \mathrm{~m}^{3} / \mathrm{s}$ whereas in 1997 it was $7,901 \mathrm{~m}^{3} / \mathrm{s}$. This resulted in an additional 42 ha (28\% increase) of rearing area available to juvenile fall chinook salmon in 1992. However, high-flow years may result in greater fish dispersal to downstream rearing habitats in McNary Reservoir. Although McNary Reservoir contains suitable fall chinook salmon rearing habitat, the available area has not been quantified and many of the shorelines are riprapped, which juvenile fall chinook salmon do not prefer (USGS, unpublished data).

Daily water level fluctuations caused by power peaking may result in net downstream movement of juvenile fall chinook salmon. Changes in flow may stimulate the downstream movement chinook salmon fry (Healey 1980; Kjelson et al. 1981; Irvine 1986), although behavioral components play a role as well (Healey 1991). We have routinely observed large schools of juvenile fish moving downstream in response to both rapid increases and decreases in flows, however the movement is more pronounced during flow increases (Loreley Clark, U.S. Geological Survey, personnal communication). Because long, contiguous shorelines of suitable habitat exist at all of the flows we modeled, fish are not likely to be displaced out of suitable habitats by short-term flow fluctuations. Their movements may, 
however, place them at greater risk of predation if they occur when predators are actively feeding.

The greatest detriment to juvenile fall chinook salmon in the Hanford Reach caused by fluctuating flows is stranding and entrapment. Because fall chinook salmon are shoreline oriented, they are susceptible to stranding on shallow slopes or being entrapped in pools when waters rapidly recede following a decrease in flow. Wagner et al. (1999), studying stranding in the Hanford Reach, found that most (99\%) juvenile fish were entrapped in pools rather than stranded on exposed substrate. The mortality of fish entrapped in pools depends upon pool size, drainage rate, exposure to lethal temperatures due to solar warming, exposure to predators, and time to reflooding and liberation.

Over 500,000 fish may have been lost due to stranding and entrapment in our study area in 1999, and mortality may have been greater in previous years (P.G. Wagner, Washington Department of Fish and Wildlife, personal communication). This prompted fishery and hydro managers to implement protective measures for Hanford Reach fall chinook salmon in 1999. Guidelines were developed based on field observations that fish were most susceptible to stranding and entrapment at flows less than 4,248 $\mathrm{m}^{3} / \mathrm{s}$. Hydro operations were not constrained when average weekly flows exceeded $4,814 \mathrm{~m}^{3} / \mathrm{s}$, except that a minimum hourly flow of $4,248 \mathrm{~m}^{3} / \mathrm{s}$ had to be maintained at Priest Rapids Dam. However, at average weekly flows less than $4,814 \mathrm{~m}^{3} / \mathrm{s}$, maximum fluctuations were restricted to $\pm 566 \mathrm{~m}^{3} / \mathrm{s}$ when no spill occurred and to $\pm 850 \mathrm{~m}^{3} / \mathrm{s}$ when spill occurred. We showed that the amount of entrapment area that existed at steady-state flows was reduced at flows greater than $4,814 \mathrm{~m}^{3} / \mathrm{s}$. However, our analysis suggests the aforementioned decreases in flow may still be a significant entrapment threat to juvenile fall chinook salmon at flows up to $5,664 \mathrm{~m}^{3} / \mathrm{s}$. For example, on April 26, 2000, the flow at Priest Rapids Dam dropped from $7,958 \mathrm{~m}^{3} / \mathrm{s}$ to $4,276 \mathrm{~m}^{3} / \mathrm{s}$, which created 26 ha of entrapment area (Figure 9). As a result, on the next day over 1,900 juvenile fall chinook salmon were found entrapped in seven small pools whose total area was less than 0.2 ha (Washington Department of Fish and Wildlife, unpublished data). This represents a fraction of the total number of fish that may have been entrapped throughout the Hanford Reach from this flow reduction.

Historically, fall chinook salmon reared under a natural hydrograph that most likely exhibited little diel fluctuation. Although the general shape of the hydrograph is still similar 
today, hydroelectric power peaking has introduced hourly and daily fluctuations that can affect the rearing potential of fall chinook salmon in the Hanford Reach. While the specific effects of habitat changes on the rearing population remain largely unexplored, the negative consequences of stranding and entrapment are apparent (Wagner et al. 1999). As such, hydro and fishery managers should, to the extent practicable, minimize flow fluctuations in the Hanford Reach. 


\section{References}

Becker, C.D. 1973. Food and growth parameters of juvenile chinook salmon, Oncorhynchus tshawytscha, in central Columbia River. U.S. National Marine Fisheries Service Fishery Bulletin 71:387-400.

Bovee, K.D. 1982. A guide to stream habitat analysis using the instream flow incremental methodology. U.S. Fish and Wildlife Service FWS/OBS-82/26. (Instream Flow Information Paper 12.)

Burrough, P.A. 1986. Principles of geographical information systems for land resources assessment. Oxford University Press, New York.

Crozier, W.W., and G.J.A. Kennedy. 1994. Application of semiquantitative electrofishing to juvenile salmonid stock surveys. Journal of Fish Biology 45:159-164.

Cushman, R.M. 1985. Review of ecological effects of rapidly varying flows downstream from hydroelectric facilities. North American Journal of Fisheries Management 5:330-339.

Dauble, D.D., R.H. Gray, and T.L. Page. 1980. Importance of insects and zooplankton in the diet of 0 -age chinook salmon (Oncorhynchus tshawytscha) in the central Columbia River. Northwest Science 54:253-258.

Dauble, D.D., and D.G. Watson. 1997. Status of fall chinook salmon populations in the mid-Columbia River, 1948-1992. North American Journal of Fisheries Management 17:283-300.

Demaris, A. 1992. Logit modeling. Sage Publications, Series 7-86, Newbury Park, California.

ESRI (Environmental Systems Research Institute, Inc.). 1998. ArcView version 3.2. Redlands, California.

Everest, F.H., and D.W. Chapman. 1972. Habitat selection and spatial interaction by juvenile chinook salmon and steelhead trout in two Idaho streams. Journal of the Fisheries Research Board of Canada 29:91-100.

Garland, R.D., and K.F. Tiffan. 1999. Nearshore habitat use by subyearling fall chinook salmon in the Snake River. Pages 53-72 in K.F. Tiffan, D.W. Rondorf, W.P. Connor, and H.L. 
Burge, editors. Post-release attributes and survival of hatchery and natural fall chinook salmon in the snake River. Annual Report to the Bonneville Power Administration, contract DE-AI79-91BP21708, Portland, Oregon.

Ghanem, A., P. Steffler, F. Hicks, and C. Katopodis. 1996. Two-dimensional hydraulic simulation of physical habitat conditions in flowing streams. Regulated Rivers: Research and Management 12:185-200.

Gislason, J.C. 1985. Aquatic insect abundance in a regulated stream under fluctuating and stable flows. North American Journal of Fisheries Management 5:39-46.

Glova, G.J., and M.J. Duncan. 1985. Potential effects of reduced flows on fish habitats in a large braided river, New Zealand. Transactions of the American Fisheries Society 114:165-181.

Gray, G.A., and D.W. Rondorf. 1986. Predation on juvenile salmonids in Columbia Basin reservoirs. Pages 178-185 in G.E. Hall and M.J. Van Den Avyle, editors. Reservoir Fisheries Management: Strategies for the 80's. American Fisheries Society, Bethesda, Maryland.

Guay, J.C., D. Boisclair, D. Rioux, M. Leclerc, M. Lapointe, and P. Legendre. 2000. Development and validation of numerical habitat models for juveniles of Atlantic salmon (Salmo salar). Canadial Journal of Fisheries and Aquatic sciences 57:2065-2075.

Guenther, G.C., R.W.L. Thomas, and P.E. LaRoacque. 1996. Design considerations for achieving high accuracy with the SHOALS bathymetric lidar survey system. SPIE: Laser Remote Sensing of Natural Waters - From Theory to Practice $2964: 54-71$.

Hardy, M.A. 1993. Regression with dummy variables. Sage Publications, Series 7-93, Newbury Park, California.

Healy, M.C. 1980. Utilization of the Nanaimo River estuary by juvenile chinook salmon, Oncorhynchus tshawytscha. Fishery Bulletin $77: 653-668$. 
Healey, M.C. 1991. Life history of chinook salmon (Oncorhynchus tshawytscha). Pages 313-393 in C. Groot and L. Margolis, editors. Pacific Salmon Life Histories. University of British Columbia Press, Vancouver.

Hosmer, Jr., D.W., and S. Lemeshow. 1989. Applied logistic regression. John Wiley and Sons, New York, New York.

Huntington, C., W. Nehlsen, and J. Bowers. 1996. A survey of healthy native stocks of anadromous salmonids in the Pacific Northwest and California. Fisheries 21(3):6-14.

Irvine, J.R. 1986. Effects of varying discharge on the downstream movement of salmon fry, Oncorhynchus tshawytscha Walbaum. Journal of Fish Biology 28:17-28.

Key, L.O., R.D. Garland, and K. Kappenman. 1996. Nearshore habitat use by subyearling chinook salmon and non-native piscivores in the Columbia River. Pages 64-79 in D.W. Rondorf and K.F. Tiffan, editors. Identification of the spawning, rearing, and migratory requirements of fall chinook salmon in the Columbia River basin. Annual Report to the Bonneville Power Administration, contract DE-AI7991BP21708, Portland, Oregon.

Kjelson, M.A., P.F. Raquel, and F.W. Fisher. 1981. Influences of freshwater inflow on chinook salmon (Oncorhynchus tshawytscha) in the Sacramento-San Joaquin estuary. Pages 88-102 in R.D. Cross and D.L. Williams, editors. Proceedings of the National Symposium on Freshwater Inflow to Estuaries. U.S. Fish and Wildlife Serivce FWS/OBS$81 / 04(2)$.

Kondolf, G.M., E.W. Larsen, and J.G. Williams. 2000. Measuring and modeling the hydraulic environment for assessing instream flows. North American Journal of Fisheries Management 20:1016-1028.

Leclerc, M., A. Boudreault, J.A. Bechara, and G. Corfa. 1995. Two-dimensional hydrodynamic modeling: a neglected tool in the Instream Flow Incremental Methodology. Transactions of the American Fisheries Society 124:645-662.

Lillycrop, W.J., L.E. Parson, and J.L. Irish. 1996. Development and operation of the SHOALS airborne lidar hydrographic system. SPIE: Laser Remote Sensing of Natural Waters - From Theory to Practice 2964:26-37. 
Lister, D.B., and H.S. Genoe. 1970. Stream habitat utilization by cohabiting underyearlings of chinook (Oncorhynchus tshawytscha) and coho ( $O$. kisutch) salmon in the Big Qualicum River, British Columbia. Journal of the Fisheries Research Board of Canada 27:1215-1224.

Orth, D.K. 1983. Aquatic habitat measurements. Pages 61-84 in L.A. Nielsen and D.L. Johnson, editors. Fisheries techniques. American Fisheries Society, Bethesda, Maryland.

Parson, L.E., W.J. Lillycrop, C.J. Klein, R.C. Ives, and S.P. Orlando. 1996. Use of lidar technology for collecting shallow bathymetry of Florida Bay. Journal of Coastal Research 13:1173-1180.

Persat, H., and G.H. Copp. 1990. Electric fishing and point abundance sampling in for the ichthyology of large rivers. Pages 197-209 in I.G. Cowx, editor. Developments in electric fishing. Blackwell Scientific Publications, Ltd., Cambridge, Massachusetts.

Rubin, S.P., T.C. Bjornn, and B. Dennis. 1991. Habitat suitability curves for juvenile chinook salmon and steelhead development using a habitat-oriented sampling approach. Rivers $2: 12-29$.

SAS. 1998. SAS/STAT user's guide, release 7.0. SAS Institute, Cary, North Carolina.

Titus, K., J.A. Mosher, and B.K. Williams. 1984. Chancecorrected classification for use in discriminant analysis: ecological applications. American Midland Naturalist $111: 1-7$.

Wagner, P.G., J. Nugent, W. Price, R. Tudor, and P. Hoffarth. 1999. 1997-99 evaluation of juvenile fall chinook stranding on the Hanford Reach. Annual Report to the Bonneville Power Administration, Contract 97BI30417, Portland, Oregon.

Watson, D.F. 1994. Contouring, a guide to the analysis and display of spatial data. Elsevier Science, New York. 


\section{CHAPTER FIVE}

Subyearling Fall Chinook Salmon Use of Shoreline Riprap Habitats in a Reservoir of the Columbia River

by

Rodney D. Garland, Dennis W. Rondorf, Kenneth F. Tiffan and Loreley O. Clark

U.S. Geological Survey

Biological Resources Division

Columbia River Research Laboratory

Cook, Washington 98605, USA 


\section{Introduction}

Shorelines are critical rearing habitats for subyearling fall chinook salmon Oncorhynchus tshawytscha in the Columbia River (Dauble et al. 1989). Hydropower development has transformed the Columbia and Snake rivers from natural alluvial systems into a series of reservoirs. Large portions of the shorelines of these impoundments are now covered with artificially created substrate (riprap) to protect roads, railroads, bridges, and levees. For example, the four lowest reservoirs on the snake River currently have approximately 156 $\mathrm{km}$ (34\%) of their shorelines armored with riprap (U.S. Army Corps of Engineers 1999).

Physical habitat characteristics are often cited as selection criteria for rearing habitats of subyearling chinook salmon. Lister and Genoe (1970) and Everest and Chapman (1972) found that subyearling spring chinook salmon in streams use coarse substrate as cover in fast current. In contrast, curet (1993) found strong selection by subyearling fall chinook salmon for substrates consisting of sand, and strong avoidance of the broken rock riprap habitats in Lower Granite Reservoir on the Snake River. Subyearling chinook salmon also tend to use water velocities not exceeding $0.3 \mathrm{~m} / \mathrm{s}$ (Everest and Chapman 1972; Glova and Duncan 1985; Hillman et al. 1987; Murphy et al. 1989).

Riprap shorelines have very different habitat characteristics compared to original riverine habitats, and contain more habitat suitable for introduced predatory fish such as smallmouth bass Micropterus dolomieui (Munther 1970; Hubert and Lackey 1980). Smallmouth bass are significant predators of subyearling fall chinook salmon in shoreline areas (Tabor et al. 1993) and it has been suggested that the predation risk subyearling fall chinook salmon are exposed to might be due to overlapping habitats (Gray and Rondorf 1986).

Information of the effect riprap habitats have on rearing subyearling fall chinook salmon is needed to make informed decisions on future shoreline modification projects. For example, one of the proposed measures to improve the survival of salmonid stocks listed under the Endangered species Act is to breach the four lower snake River dams and return the river to its natural level. If these dams are breached, an estimated 82 $\mathrm{km}$ (18\%) of $451 \mathrm{~km}$ of the newly created shoreline will be stabilized with riprap (U.S. Army Corps of Engineers 1999). The benefit or detriment of riprap habitat to subyearling fall chinook salmon is currently unknown. The objectives of this 
study were to: 1 ) determine if subyearling fall chinook salmon use riprap and natural shoreline habitats differently; 2) describe the physical characteristics of riprap and natural habitats; and 3) determine whether the presence of potential predators is associated with subyearling fall chinook salmon habitat selection.

\section{Study Area}

McNary Dam, located at river kilometer 470, impounds $98 \mathrm{~km}$ of the Columbia River, forming Lake Wallula. The Hanford Reach, located upstream of Lake Wallula, is the only unimpounded reach of the mainstem Columbia River between Bonneville Dam and the Canadian border. The Hanford Reach produces an estimated 30 million subyearling fall chinook salmon annually (Paul Wagner, Washington Department of Fish and Wildlife, personal communication), many of which rear in Lake Wallula. We conducted our study between river kilometers 506 and 538, an important rearing area in Lake Wallula with a variety of shoreline habitats, including riprap.

\section{Methods}

Use of shoreline habitats by subyearling fall chinook salmon was determined using point abundance electrofishing (Persat and Copp 1990) between dawn and dusk on three occasions: 23 May to 27 May 1994, 1 May to 4 May 1995, and 30 May to 1 June 1995. Sampling was restricted to May since this is the month of greatest nearshore abundance of subyearling fall chinook salmon in Lake Wallula. Shoreline areas were divided into two broad categories: (1) artificially created river shorelines (riprap) and (2) unmodified (natural) shorelines. We defined riprap as large broken rock substrates generally greater than $256 \mathrm{~mm}$, with little fine silt or sand filling the interstitial spaces.

We stratified our sampling to include different habitat combinations, avoid duplication of effort, and minimize sample bias. Three matrices were constructed to create different combinations of habitat variables to guide sampling, and included: (1) velocity X depth; (2) velocity X substrate; and (3) depth $\mathrm{X}$ substrate. Targeted velocities ranged from 0 to > $0.4 \mathrm{~m} / \mathrm{s}$ and were divided into $0.05 \mathrm{~m} / \mathrm{s}$ categories. Targeted depths ranged from 0 to $>3.3 \mathrm{~m}$ and were divided into $0.66 \mathrm{~m}$ categories. Substrate categories were based on a Wentworth classification modified from Orth (1983) and ranged from <1 mm 
to $>256 \mathrm{~mm}$ and were divided into five categories: $<1 \mathrm{~mm}, 1-4 \mathrm{~mm}$, 4-16 mm, 16-256 mm, and > $256 \mathrm{~mm}$.

A sample site was selected by visually estimating the water velocity, depth, and substrate at a distance before the site was reached. If our preliminary assessment indicated that the habitat features could be used, then the site was sampled and the final habitat data was added to the matrix. Sampling was spread over the entire study area to prevent concentration of effort in a single geographic area.

Effort was expended to sample the habitat combination of each matrix cell at least three times. Sampling was completed when sites could not be found to fill cells in the three matrices. A lack of some habitat types in the study area resulted in some matrix cells with few samples. Habitat with substrate categories $1-4 \mathrm{~mm}$ and 4-16 mm were generally unavailable within the study area, as were habitat with a combination of substrates $<1 \mathrm{~mm}$ and velocities $>0.3 \mathrm{~m} / \mathrm{s}$. All three matrices were filled for each sample period.

Data were collected using a $5.5 \mathrm{~m}$ electrofishing boat with two $1.0 \mathrm{~m}$ umbrella anode arrays and an electrical output of 2 amps at 60 pulses/s DC. Samples were collected by approaching the shoreline and shocking areas 2-5 m from shore, or until the boat was no longer able to advance because of shallow water depth. When a sample area was reached, a mean shock period of $13 \mathrm{~s}$ (range 3-23 s, SD 3.8) (1994), or $8 \mathrm{~s}$ (range 6-10 s, SD 0.3 ) (1995), was initiated and the boat's forward momentum stopped. Shorter shock periods were used in 1995 because they were less likely to injure subyearling fall chinook salmon. Our approach allowed a localized, stationary area to be shocked with minimal forewarning to fish. At the end of the shock, a buoy was set to mark the area where fish were observed, or the center of the shocked area if no fish were observed.

Fish were enumerated by visually identifying and counting the stunned fish observed and collecting a sample of stunned fish with dipnets (Crozier and Kennedy 1994). If we were unable to adequately identify the species of an observed fish, the fish was designated as "unknown". Captured fish were sorted by species and enumerated. Subyearling fall chinook salmon were anesthetized with $26 \mathrm{mg} / \mathrm{L}$ of tricaine methanesulfonate, weighed to the nearest $0.1 \mathrm{~g}$, and measured to the nearest $1 \mathrm{~mm}$ fork length. All fish were allowed to recover for approximately 15 min before release into the river. All work was done by 
personnel experienced with electrofishing and identification of subyearling fall chinook salmon.

Physical characteristics were measured at each site to describe habitat. Water temperature was measured to the nearest $0.1^{\circ} \mathrm{C}$ at the point of shock, and at $1 \mathrm{~m}$ and $15 \mathrm{~m}$ from shore using a thermometer certified to the standards provided by the National Institute of Standards and Technology. Mean water velocity was measured to the nearest $0.01 \mathrm{~m} / \mathrm{s}$ using a MarshMcBirney model 2000 current meter (Marsh-McBirney, Inc.; Frederick, Maryland, USA) at the point of shock and $15 \mathrm{~m}$ from shore. Water depth and flow direction were collected concurrently with water velocity measurements. Distance of the point of shock to shore was measured to the nearest $1 \mathrm{~cm}$. At the point of shock, substrate type was visually assessed and assigned a code (Orth 1983). Water turbidity was measured every $2 \mathrm{~h}$ in Nephelometric Turbidity Units (NTU) .

For statistical analyses, we used the total number of subyearling fall chinook salmon observed at each site, which we referred to as number observed per site (OPS). Mean OPS was expressed as the total number of observed subyearling fall chinook salmon divided by the number of sites. Preliminary analyses indicated that the number of subyearling fall chinook salmon observed was not normally distributed (Shapiro-Wilk; $W=$ $0.439377 ; P<0.0001)$, and the variances were significantly unequal (Folded $F=30.51 ; P<0.0001$ ), therefore nonparametric tests were appropriate. To test if all sample periods could be pooled, we ranked subyearling fall chinook salmon number observed and then conducted a two-way analysis of variance (ANOVA) on the ranked number observed with sample period and habitat type as the main effects (Zar 1984, SAS 1998). We found no difference in subyearling fall chinook salmon number observed between sample periods $(F=2.77 ; \mathrm{df}=2 ; P=0.06)$ but significant differences existed between habitat types, so we pooled data from all sample periods. We used Wilcoxon rank-sum to test the null hypothesis that there was no difference in abundance of subyearling fall chinook salmon observed in riprap and natural habitats.

We also tested the null hypothesis that there was no difference in predator abundance between natural and riprap habitats using the Wilcoxon rank-sum test. The number of predators observed at each site was summed in the same manner as subyearling fall chinook salmon. To test if all sample periods could be pooled, we ranked the number of predators observed and conducted a two-way ANOVA of the predator ranks with sample 
period and habitat type as the main effects. We found a significant difference in the number of predators observed between sample periods $(F=5.0 ;$ df $=2 ; P<0.01)$ and habitat type also being significantly different, therefore the data were not pooled.

The effects of predator presence and habitat type on subyearling fall chinook salmon abundance were examined by conducting a two-way ANOVA on ranked subyearling fall chinook salmon number observed. This statistical procedure is similar to the Kruskal-Wallis test (SAS 1998).

Mean water velocity, depth, and lateral slope were compared between riprap and natural habitats using the Wilcoxon rank-sum test because the data was not normally distributed. Lateral slope was calculated as a percent by dividing the depth at the location of the abundance sample by the distance from shore and multiplying the quotient by 100. All analyses were conducted using SAS statistical software (SAS 1998), and significance was assumed at $\alpha=0.05$.

\section{Results}

Number Observed

A total of 277 point shock abundance samples were collected resulting in observations of 1,536 subyearling fall chinook salmon. Of this total, 1,492 subyearling fall chinook salmon were observed at 218 point shock abundance sites in natural habitats and 44 subyearling fall chinook salmon observed at 59 point shock abundance sites in riprap habitats. Subyearling fall chinook salmon abundance was significantly greater in natural habitats than in riprap habitats $(Z=-4.6232 ; P<$ $0.0001)$. The mean OPS of subyearling fall chinook salmon was 6.8 in natural habitats and 0.7 in riprap habitats. Mean subyearling fall chinook salmon fork length was $49.7 \mathrm{~mm}$ ( $\mathrm{SE}$ $\pm 8.8)$.

A total of 52 predators were observed in natural habitats and 57 in riprap habitats. The mean OPS and abundance of predators was significantly greater in riprap than in natural habitats for all sampling periods (Table 1).

Predator presence was not important in explaining differences in subyearling fall chinook salmon abundance between natural and riprap habitats $(F=1.19 ; \mathrm{df}=1 ; P=0.28)$, but 
Table 1.- Summary of total samples, total observations, and mean number observed per site (OPS) of predators by sampling periods and habitat type. Sample period one was conducted from 23 May to 27 May 1994, period two from 1 May to 4 May 1995, and period three from 30 May to 1 June 1995. Also shown are $Z$ and $P$ values from the Wilcoxon rank-sum test used to compare observations between habitats by sample period.

\begin{tabular}{|c|c|c|c|c|c|c|}
\hline $\begin{array}{c}\text { Sampling } \\
\text { period }\end{array}$ & $\begin{array}{c}\text { Habitat } \\
\text { type }\end{array}$ & $\begin{array}{l}\text { Total } \\
\text { samples }\end{array}$ & $\begin{array}{c}\text { Total } \\
\text { number } \\
\text { observed }\end{array}$ & $\begin{array}{c}\text { Mean } \\
\text { OPS }\end{array}$ & $Z$ & $P$ \\
\hline \multirow[t]{2}{*}{ Period 1} & Natural & 64 & 24 & 0.4 & & \\
\hline & Riprap & 15 & 20 & 1.3 & 3.4390 & 0.0006 \\
\hline \multirow[t]{2}{*}{ Period 2} & Natural & 79 & 6 & 0.1 & & \\
\hline & Riprap & 23 & 13 & 0.6 & 3.6583 & 0.0003 \\
\hline \multirow[t]{2}{*}{ Period 3} & Natural & 75 & 14 & 0.2 & & \\
\hline & Riprap & 21 & 21 & 1.0 & 4.0010 & $<0.0001$ \\
\hline
\end{tabular}


habitat type was a significant variable $(F=10.69$; df $=1$; $P<$ $0.01)$. There was no significant interaction between habitat type and presence of predators $(F=1.19 ;$ df $=1 ; P=0.28)$.

Habitat

Riprap habitats were composed primarily of closely packed rocks and boulders that were greater than $240 \mathrm{~mm}$ in size with low embeddedness. Natural habitats were characterized by smaller substrates $(<240 \mathrm{~mm}$ ) with boulders dominant in 9\% of habitats sampled. The mean OPS of subyearling fall chinook salmon in natural boulder habitats was 1.3 compared to 0.8 in riprap habitats. Boulder habitats $(>256 \mathrm{~mm})$ had the lowest mean OPS of subyearling fall chinook salmon compared to all other types of substrate in natural habitats.

Mean depth at sample sites was significantly different between riprap and natural habitats $(Z=7.0905 ; P<0.0001)$. Most of the natural sites sampled (90\%) were between $0.1 \mathrm{~m}$ and $0.6 \mathrm{~m}$ deep, whereas $80 \%$ of the riprap habitats were between 0.4 $\mathrm{m}$ and $1.0 \mathrm{~m}$ deep. No subyearling fall chinook salmon were observed in water deeper than $0.8 \mathrm{~m}$ in natural habitats, and the mean OPS of subyearling fall chinook salmon was greatest when depth was less than $0.2 \mathrm{~m}$. In general, fish abundance in natural sites decreased as depth increased. In contrast, subyearling fall chinook salmon were observed in deeper water $(0.2 \mathrm{~m}$ to $1.0 \mathrm{~m}$ ) in riprap habitats (Figure $1 \mathrm{~A})$.

There was a highly significant difference between the lateral slope in natural and riprap habitats ( $Z=10.1262 ; P<$ $0.0001)$. Riprap habitats (82\% of sites) were steep with lateral slopes ranging from 5\% to $80 \%$. All of the observations within this range occurred between slopes of $15 \%$ and $45 \%$. Most natural habitats (94\% of sites) had lateral slopes less than 25\%. Only one subyearling fall chinook salmon was observed in natural habitats with slopes outside of this range (Figure 1B).

Mean water velocity at sample sites was not significantly different between natural and riprap habitats $(Z=0.7319 ; P=$ 0.46). Because the study habitats were located in an impoundment, most of the point abundance samples (93\%) had a water velocity $\leq 0.2 \mathrm{~m} / \mathrm{s}$. Subyearling fall chinook salmon in riprap habitats occurred in water velocity $<0.2 \mathrm{~m} / \mathrm{s}$ (range $0.0-$ $0.6 \mathrm{~m})$, whereas natural habitats contained fish in water velocity $\leq 0.45 \mathrm{~m} / \mathrm{s}$ (range $0.0-0.7 \mathrm{~m}$ ), but abundance decreased as water velocity increased (Figure 1C). 

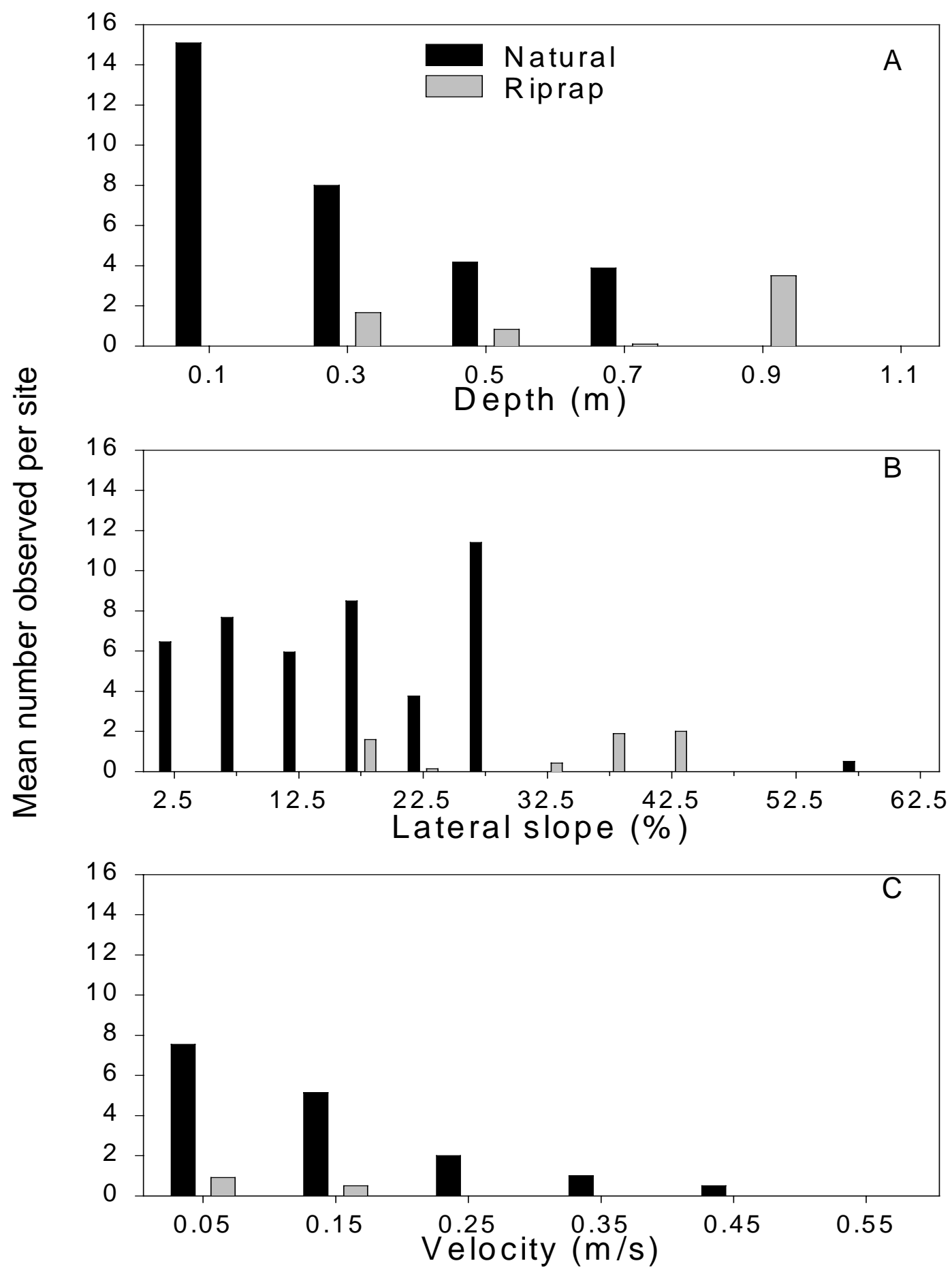

Figure 1.-Comparison of subyearling chinook salmon mean number observed per site (OPS) between natural and riprap habitat for depth (A), lateral slope (B), and velocity (C) at point abundance sites in Lake Wallula of the Columbia River, Washington during May 1994 and 1995. 


\section{Discussion}

The abundance of subyearling fall chinook salmon in Lake Wallula was much greater in natural shoreline habitats than in man-made riprap habitats. Substrate size is the most obvious difference between natural and riprap habitats. Rocks used for riprap are large and densely spaced to stabilize banks and prevent erosion. This type of substrate structure is not naturally occurring in alluvial river reaches such as the Hanford Reach, Columbia River. Where boulders occurred naturally in our study area, they were widely spaced and heavily embedded with silt, and made up a small percentage of the natural substrate available. Boulders in natural habitats were used less by subyearling fall chinook salmon than all other substrates.

Subyearling fall chinook salmon used the shallower depths and lower lateral slopes of natural shorelines more than the deeper and steeper riprap habitats. This is consistent with the findings of Dauble et al. (1989), who showed that subyearling fall chinook salmon prefer shallow waters. In unimpounded rivers, shallow water provides refuge from high water velocity and possibly protection from predators. Because riprap is usually placed on steeper banks, we could not determine whether the near absence of subyearling fall chinook salmon in riprap habitats was due to substrate size, water depth, lateral slope, or a combination of habitat variables.

Water velocity is a primary factor determining subyearling chinook salmon use of nearshore habitat in rivers and streams. Murphy et al. (1989) concluded that subyearling spring chinook salmon distribution depended primarily on water velocity, with fish using all types of natural habitat where water velocity did not exceed $0.3 \mathrm{~m} / \mathrm{s}$. Everest and Chapman (1972) found that most subyearling spring chinook salmon in two Idaho streams were found in water velocity less than $0.15 \mathrm{~m} / \mathrm{s}$. In our study, although abundance decreased with increased water velocity, there was no significant difference in water velocity between natural and riprap habitats. This was likely due to nearshore water velocity being low throughout the study area. In reservoir habitats, water velocity may be less of a determinant of habitat selection by subyearling fall chinook salmon than substrate, depth, and lateral slope.

The primary predator we observed was smallmouth bass. Smallmouth bass have been reported as a predator of subyearling fall chinook salmon in Columbia River reservoirs (Poe et al. 
1991; Rieman et al. 1991, Vigg et al. 1991; Tabor et al. 1993) and use habitats similar to riprap (Munther 1970; Hubert and Lackey 1980; Rankin 1986; Todd and Rabeni 1989). Although Rieman et al. (1991) found that smallmouth bass accounted for only a small amount of the overall predation of juvenile salmonids in John Day Reservoir, Tabor et al. (1993) reported that smallmouth bass were major predators of juvenile fall chinook salmon in nearshore rearing areas in the upper reach of Lake Wallula. Gray and Rondorf (1986) suggested that subyearlings might be at risk from predation because subyearling salmon and smallmouth bass habitat can overlap. We did not find extensive habitat overlap during the daylight hours when our sampling occurred. However, we did not sample during dawn and dusk when smallmouth bass commonly move into shallower water and feed (Kwak et al. 1992; Cole and Moring 1997). In another study, we observed an increase in numbers of smallmouth bass in shallower nearshore habitats of Lake Wallula during dusk (U.S. Geological Survey, unpublished data). Although subyearling fall chinook salmon may largely escape predation during the day by avoiding riprap habitats, there may be an increased risk of predation during dawn and dusk in natural habitats.

Point abundance electrofishing was an effective tool in collecting subyearling fall chinook salmon in our study. Unlike transect electrofishing, point abundance electrofishing samples a localized, stationary surface area. The resulting observational data is comparable between points (Persat and copp 1990) and has been used in a number of habitat studies (Copp 1991; Copp 1992; Jurajda 1999). The change in shock duration from 1994 and 1995 did not change the comparability of subyearling fall chinook salmon observations, as shock period is not a factor in collection of numeric abundances of fish when using point abundance electrofishing (Persat and Copp 1990). Fish are shocked in the first few seconds and no new fish are shocked as time progresses.

Point abundance electrofishing is limited by the depth of water (0 to $2 \mathrm{~m}$ ) that can be sampled (Persat and Copp 1990), and its efficiency is affected by fish size, fish species, turbidity, and boat operation. Larger fish and territorial predatory species such as smallmouth bass are more readily shocked by electrofishing and are more visible to dipnetters than are smaller fish (Reynolds 1996). This could result in greater efficiency in sampling predators as opposed to subyearling fall chinook salmon. High turbidity limits visibility and fish identification, and may allow fish to avoid capture (Reynolds 1996). Turbidity ranged from 2.2 to 21.2 
NTU's (mean 13.8 NTU, SD 2.4) during our study, which allowed us see to the river bottom at all depths sampled (range 0.11-1.45 m) . We observed that when shocking areas with low offshore water velocity and low gradient subyearling fall chinook salmon would more readily detect and avoid the boat, resulting in lower number of observations in these habitats. The number observed, however, was still higher in these areas than in riprap habitats. Riprap habitats generally had higher offshore flows and steeper slopes and provided less forewarning to fish.

The production of fall chinook salmon will be greatest in unimpounded alluvial habitats to which these fish are adapted. The riprap habitats that constitute a large portion of shorelines in Columbia and snake river reservoirs are very different from natural riverine habitats that support subyearling fall chinook salmon. The physical habitat characteristics of riprap such as large unembedded substrates, deep water near shore, and steep lateral slopes reduce the rearing potential for subyearling fall chinook salmon in Lake Wallula and probably other reservoirs with riprap habitat. Subyearling fall chinook salmon rearing in, or migrating through, this type of habitat may also be at a greater risk of predation. Our study shows that the future addition of riprap on shorelines would reduce the availability of rearing habitat for subyearling fall chinook salmon stocks. 


\section{References}

Cole, M.B., and J.R. Moring. 1997. Relation of adult size to movements and distribution of smallmouth bass in a Central Maine Lake. Transactions of the American Fisheries Society $126: 815-821$.

Copp, G.H. 1991. Typology of aquatic habitats in the Great Ouse, a small regulated lowland river. Regulated Rivers: Research and Management 125:125-134.

Copp, G.H. 1992. Comparative microhabitat use of cyprinid larvae and juveniles in a lotic floodplain channel. Environmental Biology of Fishes 33:181-193.

Crozier, W.W., and G.J.A. Kennedy. 1994. Application of semiquantitative electrofishing to juvenile salmonid stock surveys. Journal of Fish Biology 45:159-164.

Curet, T. 1993. Habitat use, food habits and the influence of predation on subyearling Chinook salmon in Lower Granite Reservoir, Washington. Masters Thesis, University of Idaho, Moscow, Idaho, $44 \mathrm{pp}$.

Dauble, D.D., T.L. Page, and R.W Hanf, Jr. 1989. Spatial distribution of juvenile salmonids in the Hanford Reach, Columbia River. Fishery Bulletin 87:775-790.

Everest, F.H., and D.W. Chapman. 1972. Habitat selection and spatial interaction by juvenile chinook salmon and steelhead in two Idaho streams. Journal of the Fisheries Research Board of Canada 29:91-100.

Glova, J.G., and M.J. Duncan. 1985. Potential effects of reduced flows on fish habitats in a large braided river, New Zealand. Transactions of the American Fisheries Society 114:165-181.

Gray, G.A., and D.W. Rondorf. 1986. Predation on juvenile salmonids in Columbia Basin reservoirs. Pages 178-185 in G.E. Hall and M.J. Van Den Avyle, editors. Reservoir Fisheries Management: Strategies for the 80's. Reservoir Committee, Southern Division American Fisheries Society, Bethesda, Maryland. 
Hillman, T.W., J.S. Griffith, and W.S. Platts. 1987. Summer and winter habitat selection by juvenile chinook salmon in a highly sedimented Idaho stream. Transactions of the American Fisheries Society 116:185-195.

Hubert, W.A., and R.T. Lackey. 1980. Habitat of adult smallmouth bass in a Tennessee river reservoir. Transactions of the American Fisheries Society 109:364-370.

Jurajda, P. 1999. Comparative nursery habitat use by 0+ fish in a modified lowland river. Regulated Rivers: Research and Management 15:113-124.

Kwak, T.J., M.J. Wiley, L.L. Osborne, and R.W. Larimore. 1992. Application of diel feeding chronology in habitat suitability analysis of warmwater stream fishes. Canadian Journal of Fisheries and Aquatic Sciences 49:1417-1430.

Lister, D.B., and H.S. Genoe. 1970. Stream habitat utilization by cohabiting underyearlings of chinook (Oncorhynchus tshawytscha) and coho (O. kisutch) salmon in the Big Qualicum River, British Columbia. Journal of the Fisheries Research Board of Canada 27:1215-1224.

Munther, G.L. 1970. Movement and distribution of smallmouth bass in the middle snake River. Transactions of the American Fisheries Society 99:44-53.

Murphy, M.L., J. Heifetz, J.F. Thedinga, S.W. Johnson, and K.V. Koski. 1989. Habitat utilization by juvenile pacific salmon (Oncorhynchus) in the glacial Taku River, southeast Alaska. Canadian Journal of Fisheries and Aquatic Sciences $46: 1677-1685$.

Orth, D.K. 1983. Aquatic habitat measurements. Pages 61-84 in L.A. Nielson and D.L. Johnson, editors. Fisheries Techniques. American Fisheries Society, Bethesda, Maryland.

Persat, H., and G.H. Copp. 1990. Electric fishing and point abundance sampling for the ichthyology of large rivers. Pages 197-209 in I.G. Cowx, editor. Developments in Electric Fishing. Blackwell Scientific Publications Ltd., Cambridge, Massachusetts, United Kingdom. 
Poe, T.P., H.C. Hansel, S. Vigg, D.E. Palmer, and L.A. Prendergast. 1991. Feeding of predaceous fishes on outmigrating juvenile salmonids in John Day Reservoir, Columbia River. Transactions of the American Fisheries Society 120:405-420.

Rankin, E.T. 1986. Habitat selection by smallmouth bass in response to physical characteristics in a natural stream. Transactions of the American Fisheries Society 115:322-334.

Reynolds, J.B. 1996. Electrofishing. Pages 221-253 in B.R. Murphy and D.W. Willis, editors. Fisheries Techniques, 2nd edition. American Fisheries Society, Bethesda, Maryland.

Rieman, B.E., R.C. Beamesderfer, S. Vigg, and T.P. Poe. 1991. Estimated loss of juvenile salmonids to predation by northern squawfish, walleyes, and smallmouth bass in John Day Reservoir, Columbia River. Transactions of the American Fisheries Society 120:448-458.

SAS. 1998. SAS/STAT User's Guide, Release 7.00. SAS Institute, Inc., Cary, North Carolina.

Tabor, R.A., R.S. Shively, and T.P. Poe. 1993. Predation on juvenile salmonids by smallmouth bass and northern squawfish in the Columbia River near Richland, Washington. North American Journal of Fisheries Management 13:831-838.

Todd, B.L, and C.F. Rabeni. 1989. Movement and habitat use by stream-dwelling smallmouth bass. Transactions of the American Fisheries Society 118:229-242.

U.S. Army Corps of Engineers. 1999. Lower Snake River juvenile salmon migration feasibility study. Draft Environmental Impact Statement, Walla Walla, Washington.

Vigg, S., T.P. Poe, L.A. Prendergast, and H.C. Hansel. 1991. Rates of consumption of juvenile salmonids and alternative prey fish by northern squawfish, walleyes, smallmouth bass, and channel catfish in John Day Reservoir, Columbia River. Transactions of the American Fisheries Society 120:421-438.

Zar, J.H. 1984. Biostatistical analysis, 2nd edition. Prentice-Hall, Englewood Cliffs, New Jersey. 


\section{CHAPTER SIX}

Community, Temporal, and Spatial Dynamics of Zooplankton in McNary and John Day Reservoirs, Columbia River

by

Craig A. Haskell, Dennis W. Rondorf, and Kenneth F. Tiffan

United States Geological Survey

Biological Resources Division

Columbia River Research Laboratory

Cook, WA 98605, USA 


\section{Introduction}

The Columbia River below its confluence with the Snake River is an important rearing area for subyearling chinook salmon, many of which originate from the Hanford Reach (RKm 564639). Many subyearling fall chinook salmon migrate downstream and linger in mainstem habitats during mid to late summer. The survival of chinook salmon originating in the Hanford Reach is partially attributable to reservoir productivity (Ebel et al. 1989). River conditions in mid to late summer are important for subyearling chinook salmon relative to other juvenile salmonids because they migrate later in the season when water temperatures are increasing and river flows are decreasing. Hanford Reach chinook salmon are important because they represent the majority of naturally reproducing chinook salmon in the Columbia River Basin (Huntington 1996; Dauble and Watson 1997).

A dominant prey item for subyearling chinook salmon is Daphnia spp., a common cladoceran in both McNary and John Day reservoirs of the Columbia River (Miller and Simms 1984; Rondorf et al. 1990). During mid to late summer, subyearling chinook salmon prey heavily upon Daphnia spp. not only in McNary Reservoir, but also in the Columbia River above Bonneville Dam (Muir 1988). Likewise, subyearling chinook salmon in the lower Columbia River and estuary prey heavily on cladocerans in mid to late summer (Craddock 1976, Kirn 1986). Because subyearling chinook salmon are opportunistic predators, their use of Daphnia spp. is a reflection of the seasonal increase of zooplankters. Despite their importance as prey to chinook salmon, information on zooplankton in Columbia River reservoirs is lacking.

We had three primary objectives in this study. Our first objective was to describe the composition and abundance of zooplankton taxa in McNary and John Day reservoirs. Secondly, we wanted to describe temporal and spatial differences in crustacean zooplankton abundance, Daphnia spp. biomass, and Daphnia spp. size. Our third objective was to investigate zooplankton community dynamics to make inferences about the food web structure of the Columbia River.

\section{Methods}

Study area

We conducted our study in two mainstem impoundments of the lower Columbia River, McNary and John Day reservoirs (Figure 1). 

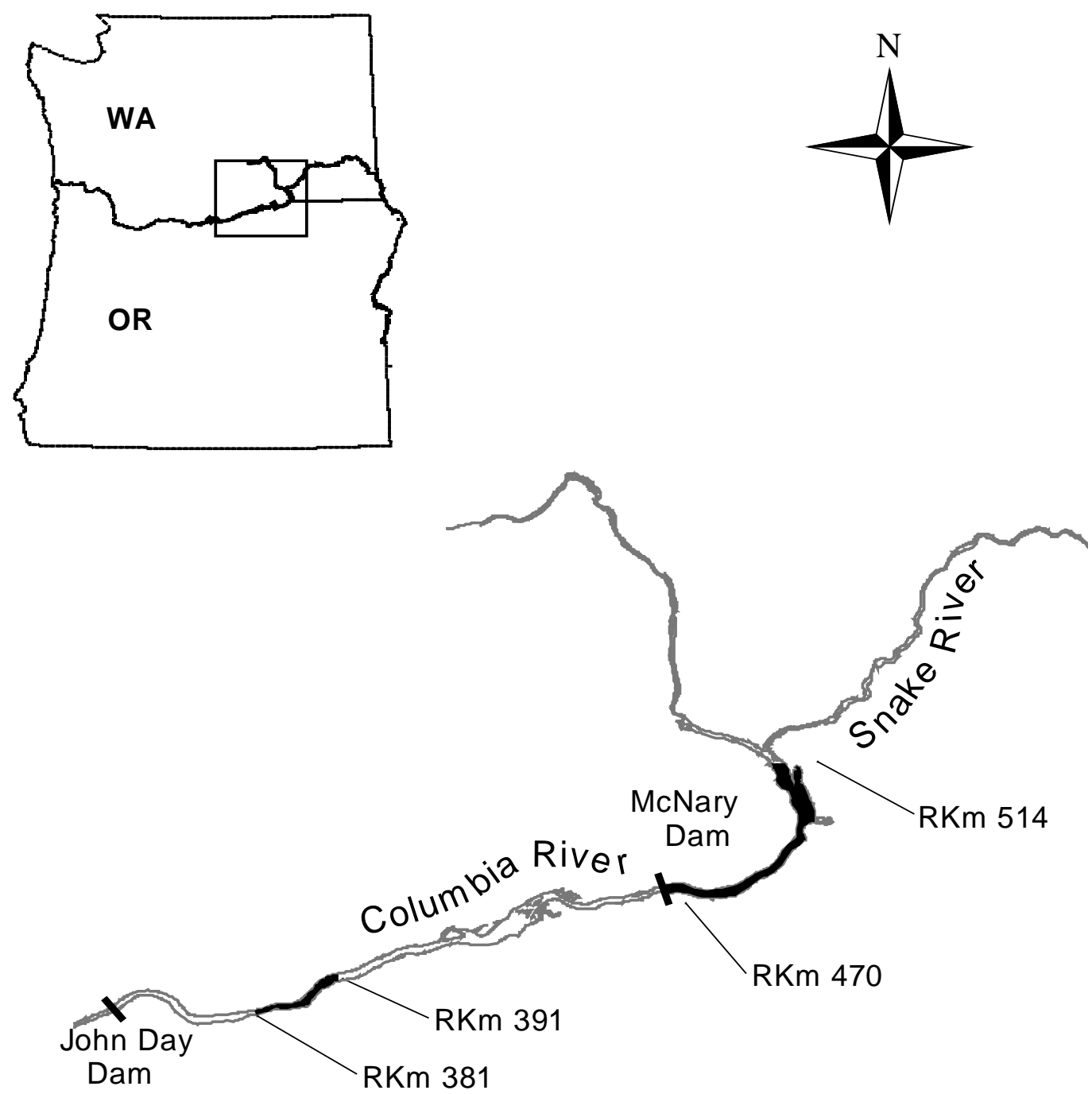

$0 \quad 40$

80 Kilometers

Figure 1. - Sampling areas for zooplankton collection in John Day and McNary reservoirs of the Columbia River. 
McNary Dam (River Kilometer (RKm) 470) impounds $98 \mathrm{~km}$ of the Columbia River to form McNary Reservoir. McNary Reservoir a surface area of $122 \mathrm{~km}^{2}$. John Day Dam (RKm 348) impounds $122 \mathrm{~km}$ of the Columbia River to form John Day Reservoir. John Day Reservoir has a surface area of $198 \mathrm{~km}^{2}$. Water temperature ranges from 2 to $21^{\circ} \mathrm{C}$ annually and the reservoirs do not exhibit thermal stratification. We sampled some areas with rip-rap shoreline and other areas which were unaltered.

Releases from Grand Coulee Dam (RKm 960), which impounds Lake Roosevelt, generally regulate the flow of downstream impoundments, including McNary and John Day reservoirs. Lake Roosevelt has a mean water retention time of 45 days. The mean water retention time in McNary Reservoir is 4.0 days and in John Day Reservoir it is 7.3 days. Water retention times in McNary and John Day reservoirs are the highest of all reservoirs downstream of Lake Roosevelt.

Sample Collection

During 1994-1996, zooplankton collections made every week during June and July in McNary Reservoir and every other week from August to October in John Day Reservoir. The beginning and ending dates of zooplankton sampling varied from year to year because they were selected to coincide with the outmigration of subyearling chinook salmon in McNary and John Day reservoirs.

We collected zooplankton samples using paired Miller samplers fitted with $153 \mu \mathrm{m}$ mesh nylon nets and internally mounted TSK flow meters to estimate the water volume sampled (Miller 1961). The samplers were towed horizontally through the water and parallel to the shoreline in an upstream direction for 5 min. Filtered samples were preserved in 10\% formalin and dyed with rose bengal stain to facilitate identification in the laboratory.

Our study areas were from RKm 381 to 391 in John Day Reservoir and from RKm 470 to 514 in McNary Reservoir. Crosssectional transects were established at 0.1-mile intervals throughout the study area. Zooplankton samples were collected at randomly selected transects. At each transect, we sampled three locations: river left (nearshore), river center (offshore), and river right (nearshore). Nearshore samples were collected approximately $20 \mathrm{~m}$ from shore, or at the closest distance at which total depth was great enough to accommodate a 5-m tow. At each location, we sampled at $0.5-\mathrm{m}$ and 5-m depths during daytime and nighttime hours. Daytime was defined as $0.5-\mathrm{h}$ after sunrise 
to 0.5-h before sunset, and nighttime was defined as $0.5-\mathrm{h}$ after sunset to $0.5-\mathrm{h}$ before sunrise. No tows were performed during the 1 -h periods encompassing sunrise and sunset. Using this strategy, a total of twelve samples were collected within each transect. This allowed us to compare cross-sectional location, depth, and diel variations in zooplankton abundance and size.

In 1995 and 1996, the river-center station was changed to the deepest point in the thalweg, and the 5-m deep tow was changed to a 3-m deep tow. This adjustment relocated the nearshore station and subsequent tows closer to shore. These changes were made to better sample nearshore and deep-water areas within the reservoir cross section.

Physical habitat data was collected for subsequent statistical analyses of size and abundance. Temperature data was collected using thermographs in McNary Reservoir at RKm 515 and in John Day Reservoir at RKm 452. We also deployed an OS2000 bathythermograph ${ }^{2}$ at each zooplankton sampling transect to obtain vertical temperature profiles of the water column. Hourly flow and daily subyearling passage indices for McNary and John Day dams were obtained from the Fish Passage Center (Portland, Oregon).

\section{Sample Processing}

In the laboratory, samples were rinsed of formalin and diluted to an abundance of at least 40 organisms/ml. Three $1-\mathrm{ml}$ aliquots were removed and zooplankton were enumerated using a binocular microscope. A Folsom splitter was used to split samples with diluted volumes greater than $4000 \mathrm{ml}$. A total count of all organisms was made for samples with volumes less than 20ml. Cladocerans other than Daphnia spp. were identified to genus. Daphnia were identified to species, categorized as male, female, or ovigerous female, and measured to the nearest 0.01 $\mathrm{mm}$. Measurements were made from the tip of the head to the posterior end of the carapace (excluding tail spine) using an ocular micrometer (Culver et al. 1985). Daphnia spp. less than $0.1 \mathrm{~mm}$ were classified as immature Daphnia spp. and were not measured. Taxonomic identification followed Ward and Whipple (1918) and Pennak (1989).

Data Analysis

Because of differences in general morphology, retention time, and seasonal sampling periods between the two reservoirs, we analyzed data from each reservoir separately with ANOVA. 
Zooplankton abundance $\left(\# \cdot \mathrm{m}^{-3}\right)$ of each taxa was calculated for each sample. The dependent variables in our analysis were mean total crustacean zooplankton, Daphnia spp. biomass, and mean Daphnia spp. size from each sample. Total zooplankton and Daphnia spp. biomass were $\log _{10}(\mathrm{X}+1)$ transformed to normalize distributions and allow for the inclusion of zero values (Zar 1984). Daphnia spp. size followed a normal distribution and was not transformed. The relationship between zooplankton parameters and environmental variables was evaluated by examining Pearson correlation coefficients. Results from statistical tests were considered significant at $P<0.05$.

Mean abundance and size of Daphnia spp. from each sample was analyzed using multiway (four factor) ANOVA to determine if significant interactions existed between year, cross-sectional sampling location, diel sampling period, and sample depth, and to test for the main effects of each variable. When three or more levels existed for a significant ANOVA main effect, a Student-Newman-Keuls test was used to compare mean abundance or size.

An interaction between two variables represented the joint effect of two or more variables above and beyond the effect of each of the variables independently. When a significant interaction occurred, we developed an interaction plot to better understand the relationship between the variables, and then used a t-test between two levels of one variable within each of the levels of the other variable (Cody and Smith 1997).

\section{Results}

Community structure and Size

We collected and analyzed 304 samples from 35 sampling dates in McNary Reservoir and 530 samples from 54 dates in John Day Reservoir. The five major zooplankton taxa collected were Bosmina longirostris, Daphnia spp., cyclopoid copepods, rotifers, and calanoid copepods (Table 1). Crustacean zooplankton sample abundance ranged from 21.8 to $30,650 \cdot \mathrm{m}^{-3}$ in McNary Reservoir and from 24.4 to $68,856 \cdot \mathrm{m}^{-3}$ in John Day Reservoir. Crustacean zooplankton abundance peaked in late July to early August in McNary Reservoir and from late August to late September in John Day Reservoir.

Seasonal abundance of Bosmina longirostris was bimodal, peaking in July in McNary Reservoir (Figure 2) and then again in 
Table 1.-Mean sample abundance (number $\cdot \mathrm{m}^{-3}$ ) and relative abundance of taxa collected in McNary and John Day reservoirs from June 1994 through October 1996.

\begin{tabular}{|c|c|c|c|}
\hline Taxa & $\begin{array}{l}\text { McNary } \\
\text { Reservoir }\end{array}$ & $\begin{array}{l}\text { John Day } \\
\text { Reservoir }\end{array}$ & $\begin{array}{l}\text { o of } \\
\text { Total }\end{array}$ \\
\hline \multicolumn{4}{|l|}{ Phylum Annelida } \\
\hline Class Oligochaeta & 2.10 & 0.19 & 0.04 \\
\hline Class Polychaeta & $<0.01$ & 0.02 & $<0.01$ \\
\hline \multicolumn{4}{|l|}{ Phylum Arthropoda } \\
\hline Class Arachnoidea & 1.10 & 2.17 & 0.04 \\
\hline $\begin{array}{l}\text { Class Crustacea } \\
\text { Order Amphipoda } \\
\text { Family Corophidae }\end{array}$ & & & \\
\hline \multicolumn{4}{|l|}{ Family Gammaridae } \\
\hline $\begin{array}{l}\text { Gammarus spp. } \\
\text { Order Cladocera } \\
\text { Family Bosminidae }\end{array}$ & $<0.01$ & - & $<0.01$ \\
\hline $\begin{array}{l}\text { Bosmina longirostris } \\
\text { Family Chydorinae }\end{array}$ & 388.69 & 2650.75 & 46.87 \\
\hline Alona spp. & 26.01 & 3.72 & 0.38 \\
\hline Chydorus spp. & 5.75 & 10.79 & 0.26 \\
\hline Plexorus spp. & 0.70 & 1.28 & 0.03 \\
\hline Leydigia Quadrangularis & 2.01 & 0.24 & 0.03 \\
\hline \multicolumn{4}{|l|}{ Family Daphnidae } \\
\hline Ceriodaphnia spp. & 12.49 & 8.76 & 0.27 \\
\hline Daphnia galeata-mendotae & 133.43 & 488.97 & 8.00 \\
\hline Daphnia parvula & 0.49 & 0.18 & $<0.01$ \\
\hline Daphnia pulex & 0.63 & 0.02 & $<0.01$ \\
\hline Daphnia retrocurva & 116.20 & 739.90 & 11.00 \\
\hline Daphnia rosea & 0.13 & 0.23 & $<0.01$ \\
\hline Daphnia schodleri & 0.12 & - & $<0.01$ \\
\hline Immature Daphnia spp. & 28.64 & 58.54 & \\
\hline Scapholeberis spp. & 0.23 & 1.57 & 0.02 \\
\hline Simocephalus spp. & $<0.01$ & $<0.01$ & $<0.01$ \\
\hline Moina spp. & 0.34 & 1.66 & 0.03 \\
\hline \multicolumn{4}{|l|}{ Family Eurycercinae } \\
\hline Camptocercus rectirostris & 0.22 & 0.08 & $<0.01$ \\
\hline Eurycercus lamellatus & 0.16 & - & $<0.01$ \\
\hline Monospilus dispar & 0.34 & 0.85 & 0.02 \\
\hline \multicolumn{4}{|l|}{ Family Leptodoridae } \\
\hline Leptodora kindtii & 2.40 & 16.65 & 0.24 \\
\hline
\end{tabular}


Family Macrothricidae Illyocryptus spp. Macrothrix spp.

0.60

0.02

0.54

0.01

Family Sididae Diaphanosoma spp.

1.30

0.01

$<0.01$

Sida Crystallina

2.72

0.98

0.03

2.67

0.07

Order Branchiura

Suborder Arguloida

$<0.01$

$<0.01$

$<0.01$

203.34

1285.15

19.13

Suborder Harpaticoida

1.15

0.68

0.02

Order Eucopepoda

Suborder Calanoida

26.71

79.01

1.36

Order Mysidacea

Family Mysidae

Neomysis mercedis

0.84

0.26

0.01

Order Podocopa

0.08

$0.04<0.01$

Class Insecta

Order Collembola

0.01

$-$

$<0.01$

Order Diptera

1.59

0.20

0.02

Order Ephemoptera

0.51

$-$

$<0.01$

Order Hemiptera

$<0.01$

$-\quad<0.01$

Order Homoptera

$<0.01$

$<0.01$

$<0.01$

Order Hymenoptera

0.03

$<0.01$

$<0.01$

Order Odanata

0.01

$-$

$<0.01$

Order Trichoptera

0.01

$-$

$<0.01$

Phylum Coelenterata

Class Hydrozoa

Order Hydroida

Family Hydridae Hydra spp.

0.20

$-\quad<0.01$

Phylum Nematoda

1.06

0.60

0.02 
Phylum Rotifera*

Phylum Tardigrada

Daphnia spp. abundance

Total crustacean zooplankton abundance
201.14

0.56

279.64

954.90
758.63

0.15

* The size of our mesh $(153 \mu \mathrm{m})$ may have underestimated the actual abundance of Rotifers. 


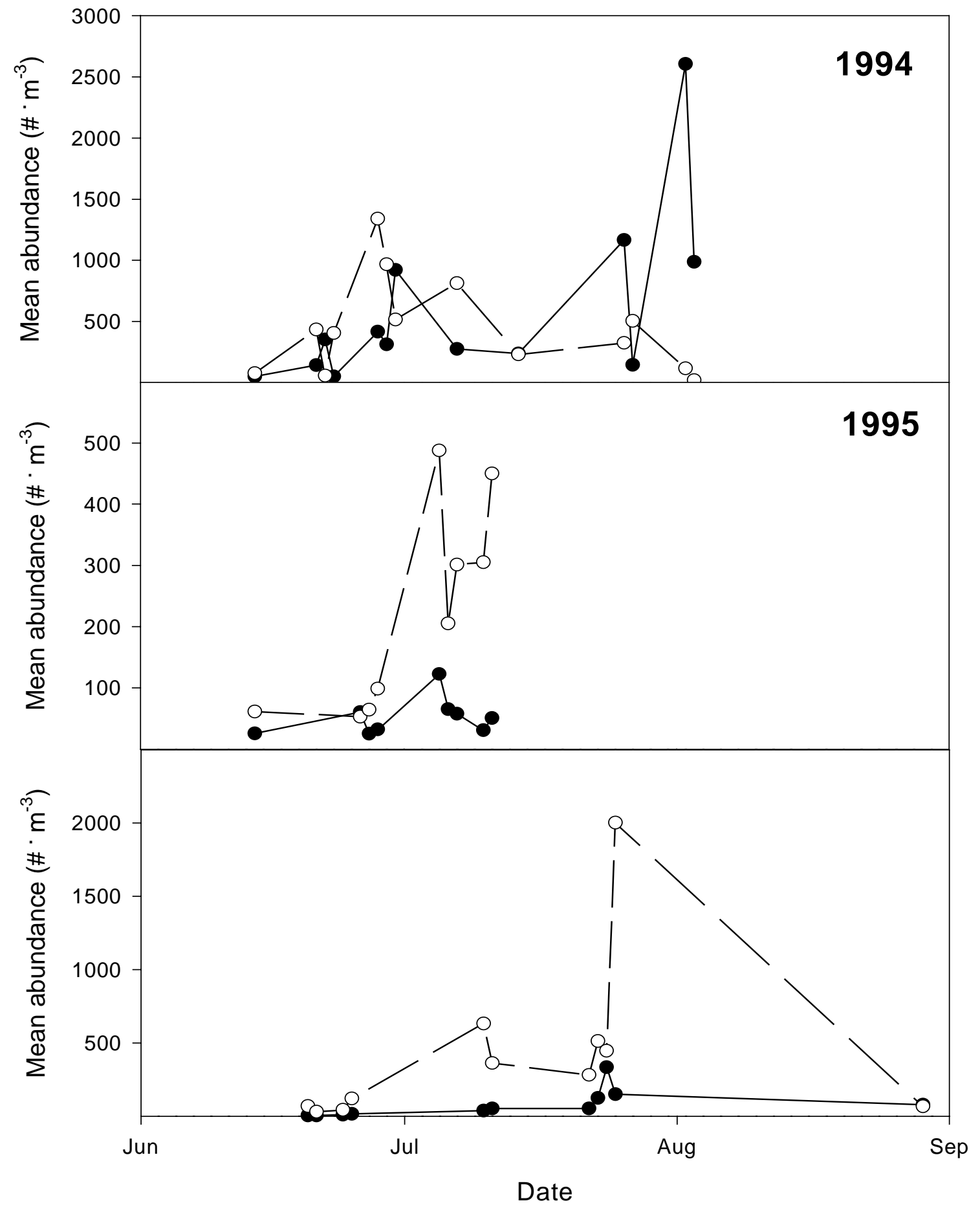

Figure 2. - Seasonal changes in mean Daphnia spp. abundance and mean Bosmina longirostris abundance from McNary Reservoir of the Columbia River, 1994-1996. Mean Daphnia spp. abundance is represented by solid circles and lines and mean Bosmina longirostris abundance is represented by open circles and broken lines. 
early October in John Day Reservoir (Figure 3). Daphnia spp. abundance peaked in early August when Bosmina longirostris numbers were seasonally low. Daphnia spp. abundance peaks generally coincided with peak total zooplankton abundance and seasonal lows in Bosmina longirostris abundance.

Mean Daphnia spp. size from sample periods ranged from 0.70 to $1.04 \mathrm{~mm}$ in McNary Reservoir (individual size ranged from 0.4 to $2.3 \mathrm{~mm}$ ) and from 0.54 to $0.98 \mathrm{~mm}$ in John Day Reservoir (individual size ranged from 0.3 to $2.2 \mathrm{~mm}$ ). Seasonal trends in mean Daphnia spp. length from sample periods indicated a reduction in Daphnia spp. mean size in John Day Reservoir in mid to late summer in all years (Table 2). In McNary Reservoir larger bodied Daphnia spp. were significantly more abundant in 1994 than in 1995 or 1996 (ANOVA, $P<0.001$ ) (Table 3). Our analysis of Daphnia spp. size in McNary Reservoir revealed a significant interaction between collection depth and diel period (ANOVA, $P=0.002$ ). After separately analyzing mean Daphnia spp size from both our shallow and deep tows during both day and night, results indicated that in the top $0.5 \mathrm{~m}$ of the water column, larger bodied Daphnia spp. were more abundant at night than during the day (ANOVA, $P<0.001$ ). In John Day Reservoir, larger Daphnia spp. were more abundant at night than during the day in all tows (ANOVA, $P<0.001$ ). Our analysis in John Day Reservoir also indicated that diel differences accounted for the greatest amount of variation in Daphnia spp. size (ANOVA, $F=$ $20.85)$.

Although our sampling design targeted crustacean zooplankton, we also encountered non-zooplankton taxa in our collections. We collected Neomysis mercedis and Corophium spp. in our samples, both of which are typically estuarine invertebrates. The mysid, Neomysis mercedis, was present in 21\% of night tows, but only 3\% of daytime tows and its abundance ranged to $54.2 \cdot \mathrm{m}^{-3}$. Corophium spp. were only detected in small numbers. We also collected small numbers of aquatic insects, predominately larval forms of Dipterans (primarily Chironimidae) .

Temporal dynamics

Seasonal patterns in crustacean zooplankton abundance and Daphnia spp. biomass were similar for both reservoirs. Mean daily crustacean zooplankton abundance ranged from $204.8 \cdot \mathrm{m}^{-3}$ to $3,354.3 \cdot \mathrm{m}^{-3}$ in McNary Reservoir (Figure 4D) and from $179.5 \cdot \mathrm{m}^{-3}$ to $39,039.5 \cdot \mathrm{m}^{-3}$ in John Day Reservoir (Figure 5D). Mean daily Daphnia spp. biomass ranged from $<0.01 \mathrm{~g}^{\cdot} \mathrm{m}^{-3}$ to $0.49 \mathrm{~g} \cdot \mathrm{m}^{-3}$ in 


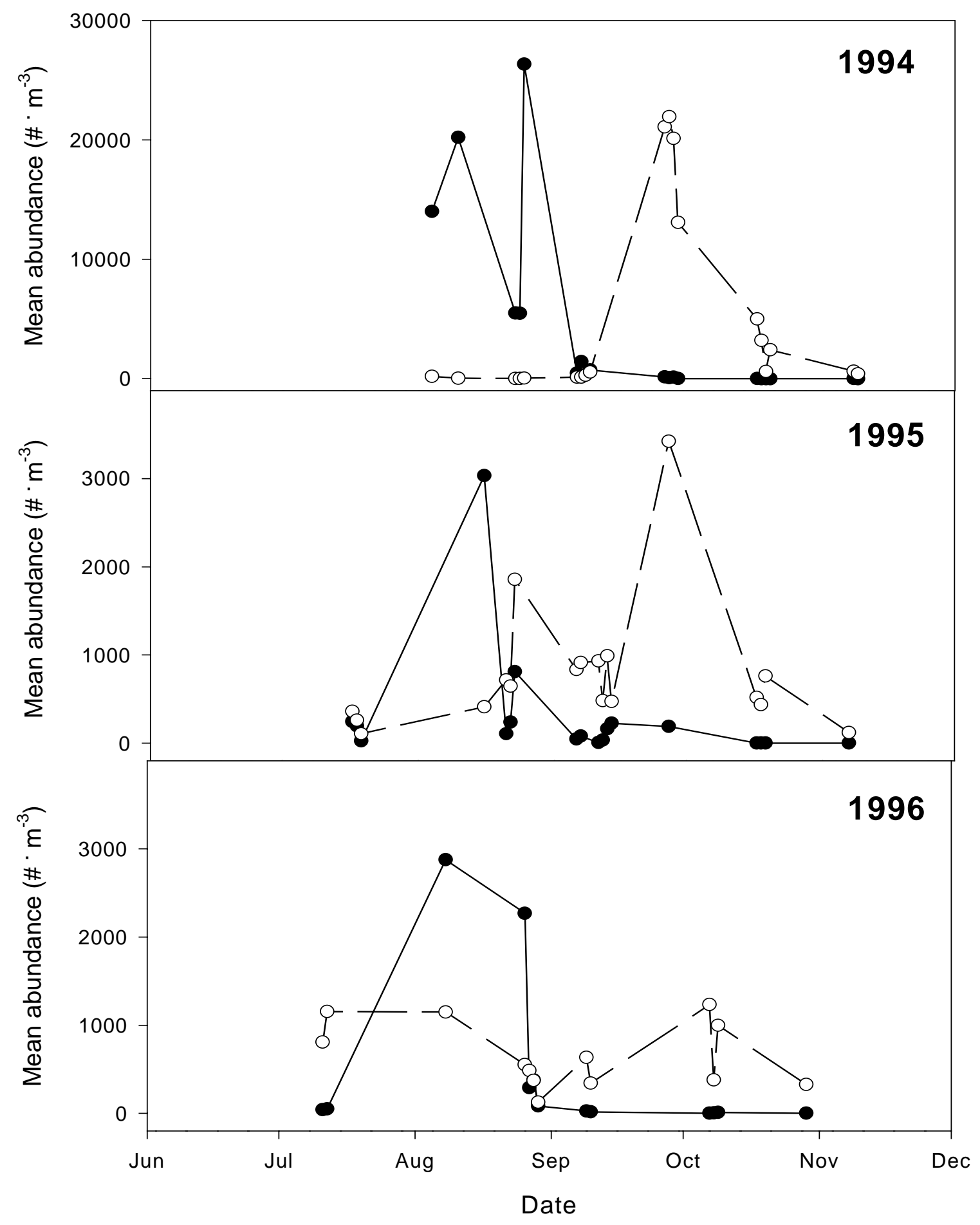

Figure 3. - Seasonal changes in mean Daphnia spp. abundance and mean Bosmina longirostris abundance from John Day Reservoir of the Columbia River, 1994-1996. Mean Daphnia spp. abundance is represented by solid circles and lines and mean Bosmina longirostris abundance is represented by open circles and broken lines. 
Table 2.-Mean length, standard error, and number of Daphnia spp. measured for each sampling period in McNary and John Day reservoirs.

\begin{tabular}{|c|c|c|c|}
\hline $\begin{array}{l}\text { Sampling } \\
\text { period }\end{array}$ & $\begin{array}{l}\text { Mean Daphnia } \\
\text { spp. length (mm) }\end{array}$ & $\begin{array}{l}\text { Number } \\
(N)\end{array}$ & $\begin{array}{c}\text { Standard } \\
\text { error }\end{array}$ \\
\hline
\end{tabular}

\section{McNary Reservoir}

\section{4}

$6 / 14$

$6 / 21-6 / 23$

0.80

0.96

$6 / 28-6 / 30$

0.93

$7 / 7$

0.98

$7 / 14$

0.96

$7 / 26-7 / 27$

0.99

$8 / 2-8 / 3$

1.04

$\begin{array}{rr}76 & 0.039 \\ 472 & 0.015 \\ 1381 & 0.008 \\ 517 & 0.017 \\ 1580 & 0.009 \\ 853 & 0.013 \\ 1241 & 0.012\end{array}$

1995

$6 / 14$

0.72

138

0.022

$6 / 26-6 / 28$

0.84

318

0.017

$7 / 5-7 / 7$

0.84

703

0.013

$7 / 10-7 / 11$

0.83

225

0.021

\section{6}

$6 / 20-6 / 25$

0.70

69

$7 / 10-7 / 11$

0.81

165

1.00

505

$8 / 29$

0.82

$10 / 9-10 / 10$

0.83

372

300

0.033

0.024

0.015

0.014

0.011

\section{John Day Reservoir}

\section{4}

\section{$8 / 4$}

$8 / 10$

$8 / 23-8 / 25$

$9 / 6-9 / 9$

$9 / 26-9 / 29$

$10 / 17-10 / 20$
0.87

0.92

0.83

0.70

0.65

0.67
767

1690

3148

1825

109

7
0.012

0.009

0.004

0.005

0.015

0.109 
$11 / 8-11 / 9$

1995

7/17-7/19

$8 / 16$

$8 / 21-8 / 23$

$9 / 6-9 / 7$

9/11-9/14

$9 / 27$

10/17-10/19

$11 / 7$

1996

$7 / 11-7 / 12$

$8 / 8$

$8 / 26-8 / 29$

$9 / 9-9 / 10$

$10 / 7-10 / 9$

$10 / 29$
0.98

0.85

0.76

0.81

0.70

0.71

0.54

0.58

0.82

0.86

0.81

0.70

0.75

0.78

0.62
15

0.103

$\begin{array}{rl}164 & 0.013 \\ 911 & 0.009 \\ 501 & 0.014 \\ 82 & 0.035 \\ 83 & 0.025 \\ 15 & 0.013 \\ 2 & 0.100 \\ 12 & 0.081\end{array}$

112

1457

570

37

33

7
0.032

0.008

0.009

0.044

0.056

0.039 
Table 3.-Significant results of four-way analysis of variance for selected zooplankton parameters in McNary and John Day reservoirs of the Columbia River from 1994-1996.

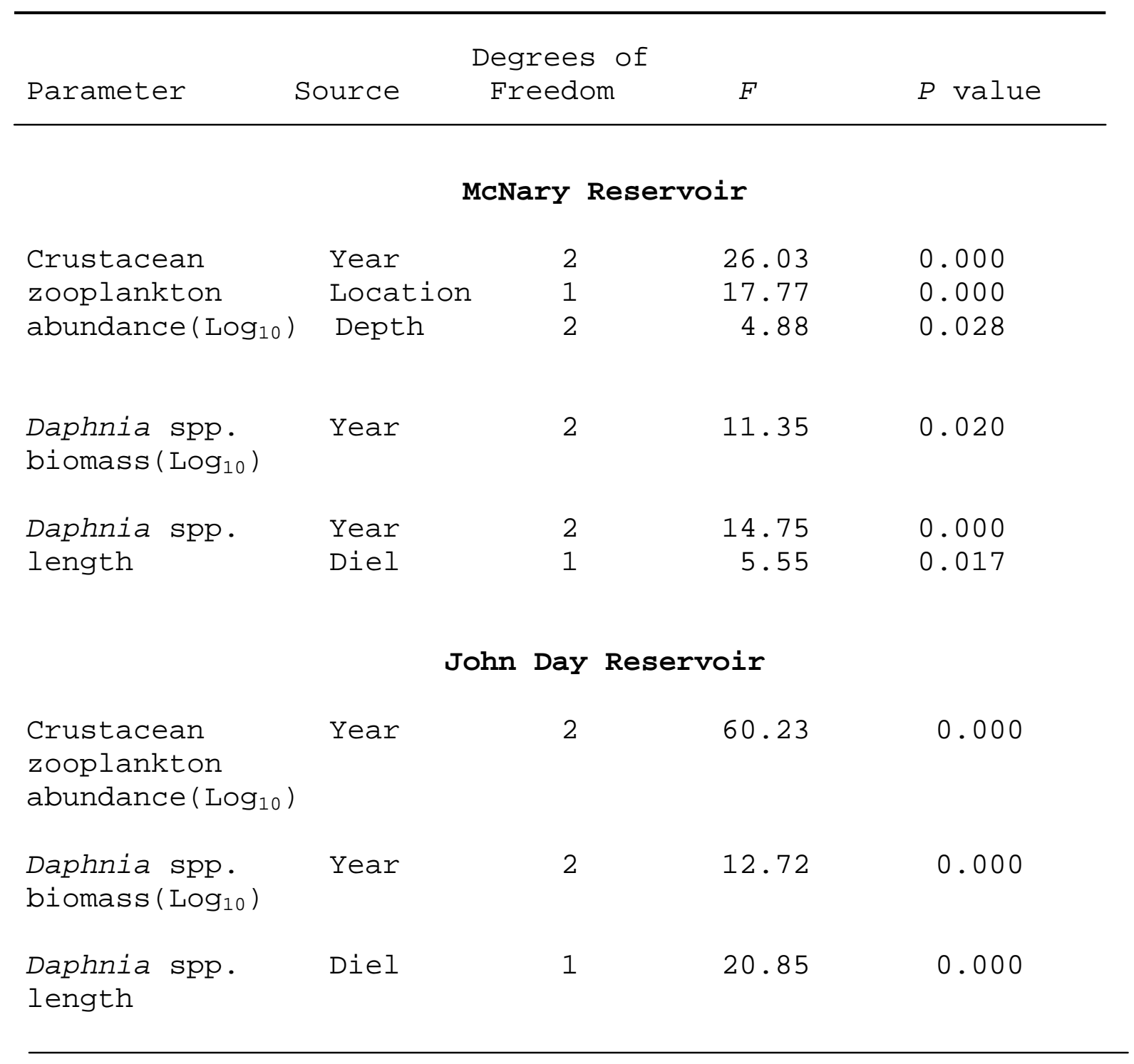




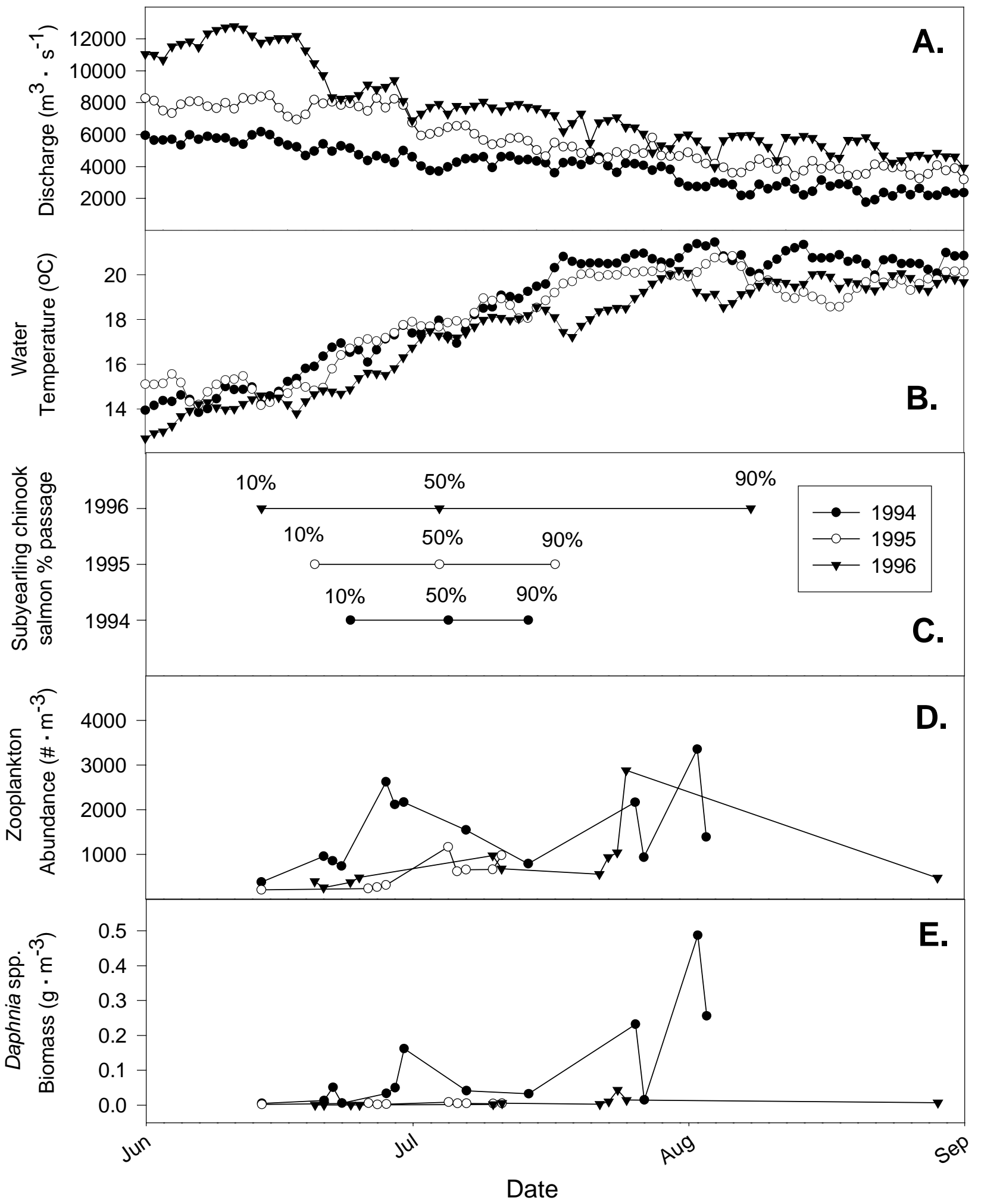

Figure 4. - Seasonal changes in A. mean daily discharge $\left(\mathrm{m}^{3} \cdot \mathrm{s}^{-1}\right)$, B. water temperature $\left({ }^{\circ} \mathrm{C}\right)$, C. percent subyearling chinook salmon passage index, $\mathbf{D}$. mean total zooplankton abundance $\left(\# \cdot \mathrm{m}^{-3}\right)$, and $\mathbf{E}$. Daphnia spp. biomass $\left(\mathrm{g}^{\cdot} \mathrm{m}^{-3}\right)$ from McNary Reservoir of the Columbia River, 1994-1996. 


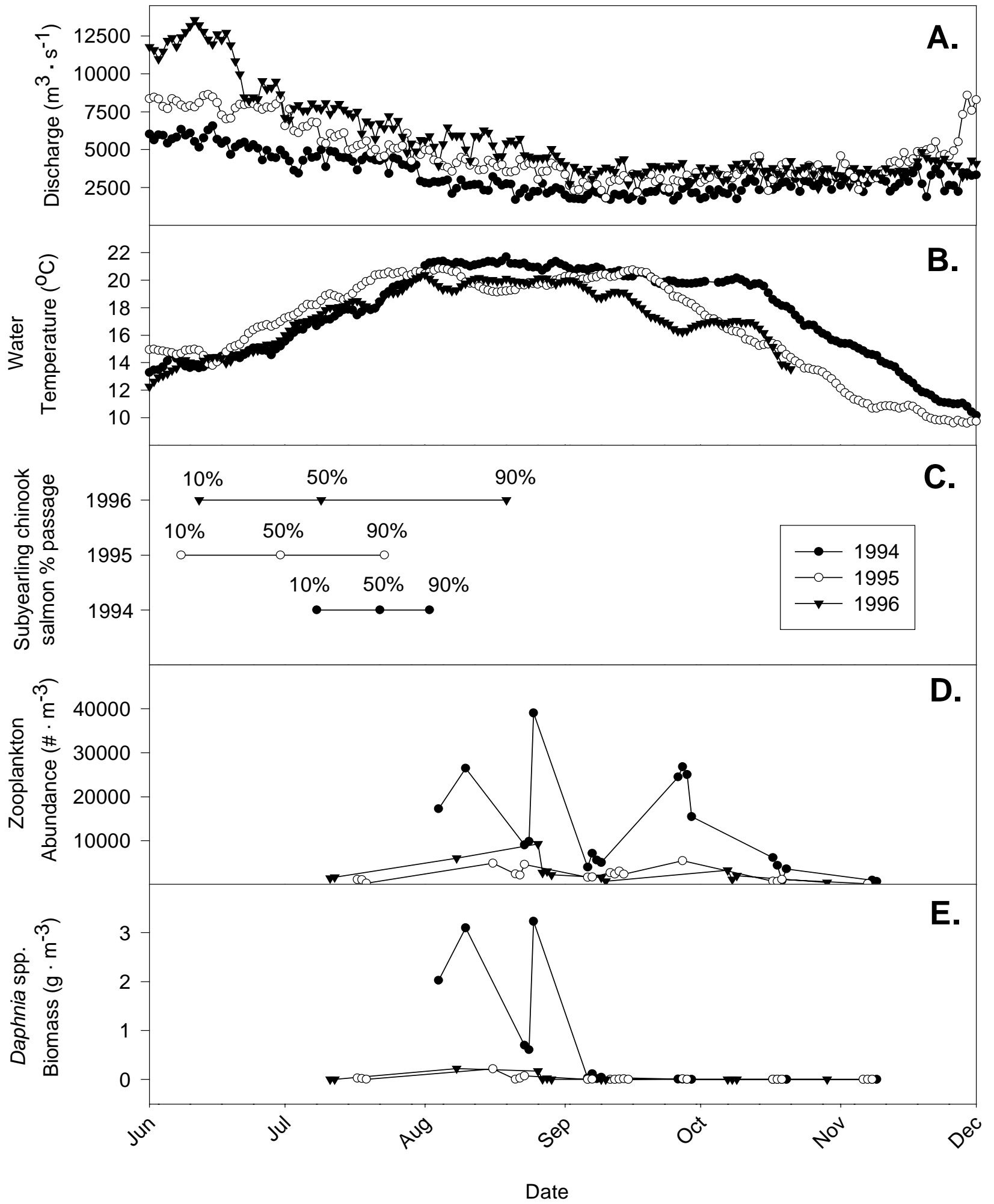

Figure 5. - Seasonal changes in A. mean daily discharge $\left(\mathrm{m}^{3} \cdot \mathrm{s}^{-1}\right), \mathbf{B}$. water temperature $\left({ }^{\circ} \mathrm{C}\right), \mathbf{C}$. percent subyearling chinook salmon passage index, D. mean total zooplankton abundance $\left(\#^{\cdot} \mathrm{m}^{-3}\right)$, and $\mathbf{E}$. Daphnia spp. biomass $\left(\mathrm{g}^{\cdot} \mathrm{m}^{-3}\right)$ from John Day Reservoir of the Columbia River, 1994-1996. 
McNary Reservoir (Figure 4E) and from $0 \mathrm{~g}^{\cdot \mathrm{m}^{-3}}$ to $3.2 \mathrm{~g}^{\cdot \mathrm{m}^{-3}}$ in John Day Reservoir (Figure 5E). In McNary Reservoir, zooplankton and Daphnia spp. biomass exhibited seasonal peaks in early July and in early August. Peaks in early July coincided with the outmigration of subyearling chinook salmon. Peaks in early August occurred at the tail end of the outmigration (Figure 4C). In John Day Reservoir, zooplankton abundance and Daphnia spp. biomass exhibited one seasonal peak in mid to late August. This peak generally occurred after the outmigration of subyearling chinook salmon (Figure 5C).

Yearly differences accounted for the greatest amount of variation in total zooplankton abundance and Daphnia spp. biomass in both reservoirs. Yearly differences also accounted for the greatest amount of variation in Daphnia spp. size in McNary Reservoir. In all cases where yearly differences were significant, mean abundance, biomass, and length were greater in 1994 (SNK test, $P \leq 0.05$ ), coinciding with higher water temperature and lower discharge.

Seasonal trends in environmental variables generally indicated higher river flows in late spring and early summer and higher water temperatures in mid to late summer (Figures 4A, 4B, $5 \mathrm{~A}$, and 5B). Over the 3-year sampling period, we collected 167 vertical temperature profiles from McNary Reservoir and 56 from John Day Reservoir. Sixty-six percent of the profiles in McNary Reservoir in 1994 had a greater than $2{ }^{\circ} \mathrm{C}$ difference between surface and bottom temperatures. Of the 171 profiles in 1995 and 1996, only four exhibited greater than a $2^{\circ} \mathrm{C}$ degree difference. The greatest variation in vertical temperature difference occurred in McNary Reservoir in 1994, when mean monthly flows were the lowest of the three years.

Seasonal increases in abundance of all the major zooplankton taxa, except rotifers, coincided with increased water temperature and decreased discharge in both reservoirs (Table 4). In McNary Reservoir, Daphnia spp. abundance was the most highly correlated with water temperature (positive correlation, $r=0.56, P=0.001$ ) and discharge (negative correlation, $r=-0.54, P=0.001)$. In John Day Reservoir, cyclopoid copepod abundance was most highly correlated with water temperature (positive correlation, $r=0.51, P=0.000$ ) and discharge (negative correlation, $r=-0.40, P=0.004$ ). 
Table 4.-Correlations, $r$, of major zooplankton taxa with temperature and discharge in McNary and John Day reservoirs of the Columbia River.

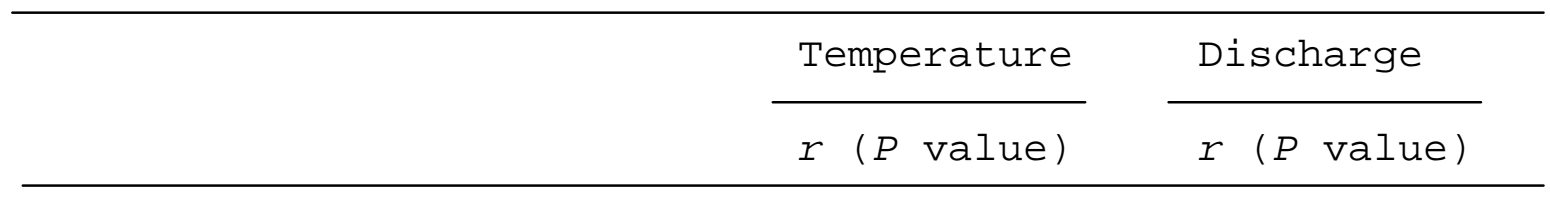

\section{McNary Reservoir}

$\begin{array}{lll}\text { Total zooplankton abundance } & 0.49(0.003) & -0.53(0.001) \\ \text { Daphnia spp. abundance } & 0.55(0.001) & -0.54(0.001) \\ \text { Bosmina logirostris abundance } & 0.17(0.334) & -0.17(0.340) \\ \text { Cyclopoid Copepod abundance } & 0.31(0.070) & -0.37(0.027) \\ \text { Calanoid Copepod abundance } & 0.07(0.708) & -0.35(0.039) \\ \text { Rotifer abundance } & 0.01(0.972) & 0.22(0.206)\end{array}$

\section{John Day Reservoir}

Total zooplankton abundance Daphnia spp. abundance Bosmina logirostris abundance Cyclopoid Copepod abundance Calanoid Copepod abundance Rotifer abundance
$0.39(0.006) \quad-0.40(0.004)$

$0.32(0.025) \quad-0.21(0.146)$

$0.09(0.525) \quad-0.29(0.045)$

$0.51(0.000) \quad-0.40(0.004)$

$0.32(0.024) \quad-0.11(0.453)$

$0.21(0.146) \quad-0.21(0.143)$ 
Crustacean zooplankton was more abundant in nearshore areas (ANOVA, $P=0.000$ ) and higher in the water column (ANOVA, $P=$ 0.028 ) in McNary Reservoir. We did not detect any significant spatial variation for total crustacean zooplankton abundance in John Day Reservoir. We did not detect any spatial variation for Daphnia spp. size or biomass in either reservoir (ANOVA, $P>$ $0.05)$.

Although not a primary objective of our study, we detected greater mean abundance of all major taxa in John Day Reservoir (RKm 390) than in McNary Reservoir (RKm 510) from three periods where we sampled both reservoirs concurrently (Figure 6).

\section{Discussion}

Zooplankton populations in large riverine reservoirs are strongly influenced by physical factors. Reservoirs with low retention times such as those on the mainstem Columbia River may favor smaller-bodied zooplankters, which generally have shorter generation times. The dominant taxa in our study of McNary and John Day reservoirs were Bosmina spp., copepods, rotifers, and smaller Daphnia spp. These findings are consistent with those from other rivers with low retention times such as the Orinoco River, Venezuela (Saunders and Lewis 1989), the Ohio River (Pace et al. 1992), and the Hudson River (Thorp et al. 1994).

Physical factors may be responsible for the lack of crosssectional and vertical temperature variation that we observed. The low retention times of middle and lower columbia River reservoirs are primarily responsible for the absence of thermal stratification within the water column. However, our results indicate that during low-flow years, surface warming and stronger vertical temperature gradients develop.

Greater nearshore or littoral crustacean zooplankton abundance in McNary Reservoir may be the result of higher retention of zooplankton in lower water velocity habitats. The Ohio River exhibited greater mean annual abundances of cladocerans and copepods in littoral areas during the summer (Thorp et al. 1994). High winds, seasonally common to our study area in John Day Reservoir, may create enough turbulence to further mix the water. In most reservoirs, wind is the primary force that invokes mixing (Marzolf 1990). The lack of crosssectional variation in John Day Reservoir may be somewhat 


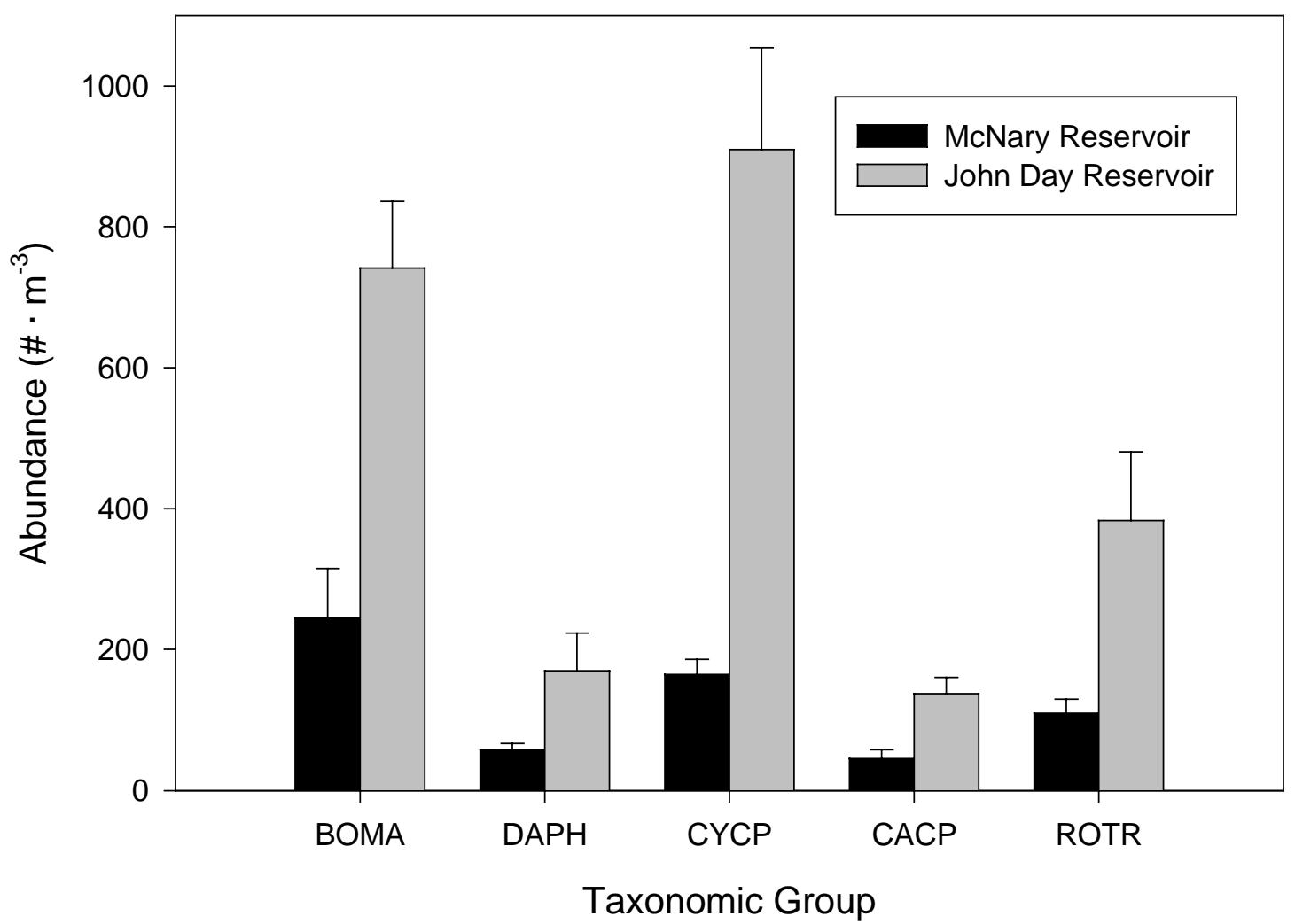

Figure 6. - Mean abundance $\left(\# \cdot \mathrm{m}^{-3}\right)$ with standard error bars in McNary ( $R K m$ 510) and John Day ( $R K m$ 389) reservoirs of the Columbia River when samples were collected concurrently (July, August, and October, 1996). BOMA, DAPH, CYCP, CACP, and $\mathrm{ROTR}=$ abundance of Bosmina longirostris, Daphnia spp., Cyclopoid Copepods, Calanoid Copepods, and Rotifers, respectively. 
attributable to our study design because we did not sample in water less than $3 \mathrm{~m}$ in depth (5 m depth in 1995 and 1996). Due to the nature of our sampling design, we did not sample tributary and backwater populations that may have exhibited greater abundance than mainstem sampling locations.

In the upper reaches of rivers, river flow is too high to allow for the establishment of zooplankton in main channel areas, because zooplankton decreases due to downstream transport are greater than production in a given area (Hynes 1970). Decreased flows and sedimentation in backwater areas may allow for the establishment of zooplankton communities, which can be advected into the main channel. These occurrences may be magnified in backwater areas of the lower river where flows are low enough for the establishment of populations of zooplankton in the mainstem portion of the river.

Saunders and Lewis (1989) found significant downstream increases in copepod and Bosmina abundance in mainstem habitats that could not be attributed to tributary inputs and transitory reproduction in the Orinoco River, Venezuela. This indicated that zooplankters were originating from areas within the mainstem. It may be possible for downstream increases in zooplankton to occur above and beyond tributary or backwater inputs. We believe that mainstem zooplankton abundance in McNary and John Day reservoirs is determined by both advection from backwater areas and by mainstem production.

According to the river discontinuity concept developed by Ward and Stanford (1983), high dams have the effect of resetting the biotic community to that of a lower order river. Application of this theory to the Columbia River suggests that McNary and John Day reservoirs exhibit longitudinal abundance increases from tailrace to forebay, however differences between reservoirs would be dependent on the retention time of each. Zooplankton abundance in McNary Reservoir is highest in forebay reaches and lowest in riverine reaches (Rondorf et al. 1990).

The composition of cladoceran zooplankton taxa in our study was similar to that described for McNary Reservoir by Scarola (1968) and the Hanford Reach of the Columbia River (Neitzel et al. 1982). Our study found six species of Daphnia, with Daphnia retrocurva and Daphnia galeata-mendotae being the most abundant, both of which are reported in the literature of Columbia River zooplankton (Scarola 1968; Rondorf et al. 1990). Daphnia rosea was reported in the upper Columbia by Beckman et al. (1985). Daphnia pulex, Daphnia parvula, and Daphnia schodleri were 
reported in the lower snake River by Harris (1979). We did not document the presence of Daphnia middendorffiana as reported by Neitzel et al. (1982) in the Hanford Reach. These discrepancies may be due in part to the seasonal differences in Daphnia morphology and hybridization between species (Pennak 1989). We found no other mention of Camptocercus rectirostris or Moina spp. collected in these areas.

Seasonal abundance patterns exhibited by Bosmina longirostris and Daphnia spp. in our study were similar to those shown in other studies. Bosmina longirostris abundance typically is bimodal with peaks in early summer and early autumn. Daphnia retrocurva, the primary Daphnid specie in our study, typically has one seasonal maximum when water temperature exceeds $20^{\circ} \mathrm{C}$, while Daphnia galeata mendotae has two seasonal maxima (Wetzel 1983). The Daphnid specie available to subyearling chinook salmon in our study area is predominately Daphnia galeata mendotae. The abundance of Bosmina longirostris is usually controlled by the abundance of flagellated algae, whereas Daphnia spp. abundance may be influenced by predation because of their larger size.

We collected two estuarine invertebrates, Corophium spp. and Neomysis mercedis, in both McNary and John Day reservoirs. Both invertebrates are typically estuarine but have become established in Columbia and snake river reservoirs. Corophium salmonis and Corophium spinicorne are important food resources of juvenile salmonids in Lower Granite Reservoir of the Snake River (Muir and Coley 1996), the Bonneville Pool (Muir and Emmet 1988), and the lower Columbia River (Kirn et al. 1986). Unlike Corophium spp., Neomysis mercedis is not an important food source of juvenile salmonids and may be largely unavailable as prey due to its diel migration within the water column. Although mysids have had large-scale impacts on food web interactions in other systems, little is known about the possible effects of Neomysis mercedis on food webs in the Columbia River and their implications for salmonid stocks.

Seasonal variability in water temperature and discharge influences the number of Daphnia spp. available to fishes in the Columbia River. Temperature and discharge patterns in mainstem Columbia River impoundments favor planktivores in mid to late summer when zooplankton abundance is at a maximum. A reduction in cladoceran body size may be an indication of plankivory (Brooks and Dodson 1965). In John Day Reservoir, juvenile American shad (Alosa sapidissima) were the most abundant fish collected in mid-water trawls conducted during August and 
September, 1994-1996 (Haskell, U.S. Geological Survey unpublished data), and second only to cottids as larvae from June-Aug (Gadomski and Barfoot 1997). Juvenile American shad may be responsible for the decline in Daphnia spp. abundance and size during August and September. Because subyearling chinook salmon are at least partially planktivorous during this time period (Rondorf et al. 1990), interactions between juvenile chinook salmon and American shad for food resources may warrant further investigation. Although we identified the role of water temperature and discharge in zooplankton dynamics, we did not explore the role of juvenile American shad and juvenile chinook salmon planktivory. 


\section{References}

Beckman, L.G., J.F. Novotny, W.R. Persons, and T. T. Terrell. 1985. Assessment of the fisheries and limnology in Lake Roosevelt, 1980-1983. U.S. Fish and Wildlife Service. Final Report to U.S. Bureau of Reclamation. Contract No. WPRS-007-10-X0216; FWS-14-06-009-904, May 1985. 168 pp.

Brooks, J.L, and S.I. Dodson. 1965. Predation, body size, and composition of plankton. Science 150:28-35.

Craddock, D.R., T.H. Blahm, and W.D. Parente. 1976. Occurrence and utilization of zooplankton by juvenile chinook salmon in the lower Columbia River. Transactions of the American Fisheries Society 105:72-76.

Cody, R.P., and J.K. Smith. 1997. Applied statistics and the SAS programming language. $4^{\text {th }}$ ed. Prentice Hall Inc., Upper Saddle River, New Jersey.

Culver, D.A., M.A. Boucherle, D.J. Bean, and J.W. Fletcher. 1985. Biomass of freshwater crustacean zooplankton from length-weight regressions. Canadian Journal of Fisheries and Aquatic Sciences 42:1380-1390.

Dauble, D.D., and D.G. Watson. 1997. Status of fall chinook salmon populations in the Mid-Columbia River, 1948-1992. North American Journal of Fisheries Management 17:283-300.

Demott, W.R. 1989. The Role of Competition in Zooplankton Succession. In U. Sommer (ed.) Plankton Ecology: Succession in Plankton Communities. Springer-Verlag, New York. pp. 195-252.

Ebel, J.W., C.D. Becker, J.W. Mullan, and H.L. Raymond. 1989. The Columbia River-toward a holistic understanding. In D.P. Dodge (ed.) Proceedings of the International Large River Symposium. Canadian Special Publication of Fisheries and Aquatic Sciences 106:205-219.

Gadomski, D.M., and C.A. Barfoot. 1998. Diel and distributional abundance patterns of fish embryos and larvae in the lower Columbia and Deschutes rivers. Environmental Biology of Fishes $51: 353-368$. 
Harris, M.J. 1979. Planktonic Microcrustacea of the Lower Snake River Drainage. Northwest Science 53:63-70.

Huntington, C.S., W. Nehlsen, and J. Bowers. 1996. A survey of healthy native stocks of anadromous salmonids in the Pacific Northwest and California. Fisheries 21:6-14.

Hynes, H.B.N. 1972. The Ecology of Running Waters. University of Toronto Press. Downsview, Ontario.

Kirn, R.A., R.D. Ledgerwood, and A.L. Jensen. 1986. Diet of subyearling chinook salmon (Oncorhynchus tshawytscha) in the Columbia River Estuary and changes affected by the 1980 eruption of Mount St. Helens. Northwest Science 60:191-196.

Marzolf, R.G. 1990. Reservoirs as Environments for Zooplankton. In K.W. Thornton, B.L. Kimmel, and F.E. Payne (eds.) Reservoir Limnology: Ecological Perspectives. John Wiley \& Sons, Inc., New York. pp. 195-208.

Miller, D. 1961. A modification of the small Hardy plankton sampler for simultaneous high-speed plankton hauls. Bulletin of Maritime Ecology 5:165-172.

Miller, D.R., and C.W. Simms. 1984. Effects of flow on the migratory behavior and survival of juvenile fall and summer chinook in John Day Reservoir. Annual Report to Bonneville Power Administration, Portland, Oregon.

Muir, W.D., and R.L. Emmit. 1988. Food habits of migrating smolts passing Bonneville Dam in the Columbia River. Regulated Rivers: Research and Management 2:1-10.

Neitzel, D.A., T.L. Page, and R.W. Hanf, Jr. 1982. MidColumbia River zooplankton. Northwest Science 57:112-118.

Pace, M.L., S.E.G. Findlay, and D. Lints. 1992. Zooplankton in advective environments: the Hudson River community and a comparative analysis. Canadian Journal of Fisheries and Aquatic Sciences 49:1060-1069.

Pennak, R.W. 1989. Fresh-Water Invertebrates of the United States. John Wiley and Sons, Inc. New York.

Rondorf, D.W., G.A. Gray, and R.B. Fairley. 1990. Feeding ecology of sub-yearling chinook salmon in riverine and 
reservoir habitats of the Columbia River. Transactions of the American Fisheries Society 119:16-24.

Saunders, J.F. III and W.M. Lewis Jr. 1989. Zooplankton

abundance in the lower Orinoco River, Venezuela. Limnology and Oceanography 34:397-409.

Scarola, J.F. 1968. Cladocera and Copepoda in McNary Reservoir, 1965-1966. Northwest Science 42:112-114.

Thorp, J.H., A.R. Black, K.H. Haag, and J.D. Wehr. 1994. Zooplankton assemblages in the Ohio River: seasonal, tributary, and navigation dam effects. Canadian Journal of Fisheries and Aquatic Sciences 51:1634-1643.

Ward, H.B., and G.C. Whipple. 1918. Freshwater Biology. John Wiley and Sons, Inc. New York.

Ward, J.V., and J.A. Stanford. 1983. The Serial Discontinuity Concept of Lotic Ecosystems. In T.D. Fontaine III, and S.M. Bartell (eds.). Dynamics of Lotic Ecosystems. Ann Arbor Science. Ann Arbor, Michigan. pp. 29-42.

Wetzel, R.G. 1983. Limnology. 2nd ed. Saunders College Publishing. Philadelphia, Pennsylvania.

Zar, J.H. 1984. Biostatistical Analysis. 2nd ed. Prentice Hall. Englewoods Cliffs, New Jersey. 